Sheila Fernandes Pimenta e Oliveira Vânia de Fátima Martino Genaro Alvarenga Fonseca (org.)

\title{
Formação de Professores: entre vivências e reflexões
}

Coleção Educação e Educandos
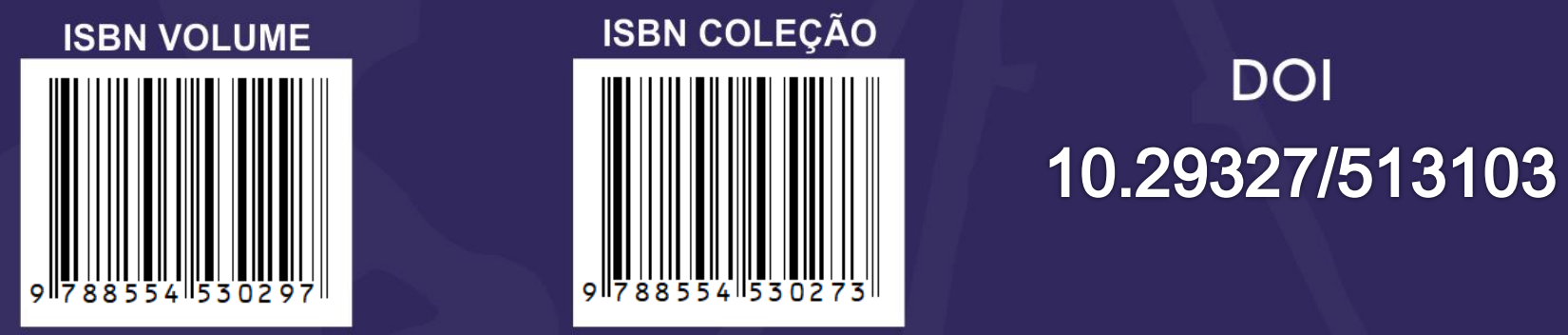
FORMAÇÃO DE PROFESSORES: entre vivências e reflexões 

Sheila Fernandes Pimenta e Oliveira

Vânia de Fátima Martino

Genaro Alvarenga Fonseca (org.)

FORMAÇÃO DE PROFESSORES: ENTRE VIVÊNCIAS E REFLEXÕES

ISBN 978-85-5453-029-7

FRANCA

Uni-FACEF/UNESP

2019 


\section{Comissão Científica}

Alessandra David (Centro Universitário Moura Lacerda)

Ana Lúcia Furquim Campos-Toscano (Uni-FACEF)

Célia Maria David (UNESP)

Fernando Silva Ribeiro (Universidade Estadual de Goiás)

Genaro Alvarenga Fonseca (UNESP)

Hilda Maria Gonçalves da Silva (UNESP)

Joana Correa Goulart (Universidade Estadual de Goiás)

Karina de Melo Conte (Centro Universitário Claretiano)

Karina Elizabeth Serrazes (Centro Universitário Claretiano)

Lucinda de Fátima Maria Coelho Rodrigues (Uni-FACEF)

Lucimary Bernabé Pedrosa de Andrade (FFCL)

Márcia Pereira da Silva (UNESP)

Maria Eloísa de Souza Ivan (Uni-FACEF)

Maria Madalena Graciloi (FFCL)

Maria Sílvia Pereira Rodrigues Alves Barbosa ((Uni-FACEF)

Pricila Bertanha (Centro Universitário Claretiano)

Sheila Fernandes Pimenta e Oliveira (Uni-FACEF)

Sílvia Regina Viel (Uni-FACEF)

Sílvio Carvalho Neto (Uni-FACEF)

Vânia de Fátima Martino (UNESP)

Tatiana Noronha de Souza (UNESP)

Welton Roberto Silva (Uni-FACEF)

\section{Conselho Editorial}

Ana Cláudia da Silva (UnB)

Antônio Carlos Petean (UFU)

Daniela Melaré Vieira Barros - Universidade Aberta / Portugal

Danilo Seithi Kato (UFTM)

Genaro Alvarenga Fonseca (UNESP)

Sheila Fernandes Pimenta e Oliveira ((Uni-FACEF)

Sílvio Carvalho Neto (Uni-FACEF)

Teise de Oliveira Guaranha Garcia - FFCLRP / USP

Vânia de Fátima Martino (UNESP) 
(c) 2019 dos autores

Direitos de publicação Uni-FACEF

www.unifacef.com.br

Coleção: Educação e Educandos, v.3. 

Oliveira, Sheila Fernandes Pimenta e (Org.)
Formação de professores: entre vivências e reflexões. / Sheila Fernandes Pimenta e Oliveira; Vânia de Fátima Martino; Genaro Alvarenga Fonseca (org).
- Franca: Uni-FACEF; Unesp/Franca; 2019. (Coleção: Educação e educandos, v. 3). 120p.; il.

ISBN Coleção978-85-5453-027-3

ISBN Volume: 978-85-5453-029-7

DOI 10.29327/513103

1.Educação - Pesquisa. 3.Experiências e vivências.
2. Formação de professores.

I.T.

CDD 370

TODOS OS DIREITOS RESERVADOS.

É proibida a reprodução total ou parcial, de qualquer forma ou por qualquer meio. A violação dos direitos de autor (lei no. 9.610/98) é crime estabelecido pelo artigo 184 do código Penal. Todo o conteúdo apresentado neste livro é de responsabilidade exclusiva de seus autores.

Editora Uni-FACEF Centro Universitário Municipal de Franca

Associada à ABEC - Associação Brasileira de Editores Científicos 


\section{PREFÁCIO}

O livro Formação de Professores apresenta-se como parte da Coleção Educação e Educandos, organizado por ocasião do VII Simpósio de Educação e IV Encontro Internacional de Políticas Públicas em Educação. O evento que possibilitou a feitura desta obra é fruto da parceria de duas instituições de renome: a UNESP e o UniFACEF, cuja finalidade é discutir e repensar caminhos para os profissionais envolvidos com a educação.

Estas instituições formadoras de professores e docentes, que atua direta ou indiretamente com a educação, têm promovido ao longo de sua história, pesquisas, projetos, produções bibliográficas, fruto de um trabalho que une graduação, pósgraduação e comunidade. O livro aqui apresentado tem a assinatura de todos estes profissionais, empenhados em discutir rigorosamente possibilidades de transformar a realidade educacional em nosso país.

Neste volume, estão reunidos estudos, experiências de docentes da rede básica de ensino e do ensino superior, pesquisas de alunos de pós-graduação e graduação, unindo investigadores da área, em uma visão interdisciplinar. As vivências e as reflexões aqui apresentadas tratam de temas como: práticas pedagógicas, licenciaturas, história da educação de professores, metodologias de ensino, currículo, estágios supervisionados, todos a partir de diferentes olhares. Ainda, é possível ver nestas páginas experiências em projetos como PIBID (Programa Institucional de Bolsa de Iniciação a Docência/CAPES) e RP (Residência Pedagógica/CAPES), desenvolvidos pelas instituições parceiras e outras em nível regional e estadual.

O objeto central desta obra, a Formação de Professores, é assunto que permeia todo o contexto da educação, visto que está diretamente relacionado à qualidade dos processos de ensino e aprendizagem, do ambiente escolar, das políticas públicas e dos profissionais que atuam na formação dos educando em diferentes realidades e contextos.

Este tema trata fundamentalmente da educação inicial dos futuros professores, tanto em programas presenciais quanto a distância, com múltiplos currículos, perfis dos egressos, abordando na sequência os programas de formação continuada, tão importante quanto os iniciais. Entendemos que é impossível dissociar 
um do outro, tendo em vista que a formação é um processo que permeia toda a vida do educador. O mundo em constante transformação demanda um profissional adequado, atualizado e fundamentalmente comprometido com a educação e isto se dá via diferentes ações individuais, coletivas e institucionais.

Esperamos que estas páginas proporcionem, aos leitores, momentos de aprendizagem, reflexão e revisão de perspectivas no caminho de uma educação melhor para todos.

Prof ${ }^{\mathrm{a}} \mathrm{Dr}^{\mathrm{a}}$ Vânia de Fátima Martino Docente da Faculdade de Ciências Humanas e Sociais Unesp/Franca 


\section{SUMÁRIO}

A FORMAÇÃO CONTINUADA DOS PROFESSORES DO ATENDIMENTO EDUCACIONAL ESPECIALIZADO

A FORMAÇÃO DE PROFESSORES NO CURSO DE PEDAGOGIA E O USO DE METODOLOGIAS ATIVAS: Alunos protagonistas, docentes qualificados 18

A TUTORIA A DISTÂNCIA: Sua função e suas responsabilidades

A VISÃO DO ESTUDANTE DE MEDICINA SOBRE AS TUTORIAS E O PAPEL DO PROFESSOR-TUTOR EM ABP (APRENDIZADO BASEADO EM PROBLEMAS), À LUZ DA ANÁLISE DISCURSIVA

FORMAÇÃO DO PROFESSORADO PAULISTA: Um estudo da Revista Escolar (1925 - 1927)

O ENSINO DA LÍNGUA PORTUGUESA: A importância do estágio supervisionado na busca por novas abordagens de ensino

PRÁTICAS AVALIATIVAS NA DISCIPLINA DE HISTÓRIA DA EDUCAÇÃO: A percepção dos futuros professores

PRÁTICAS E METODOLOGIAS NA FORMAÇÃO ACADÊMICA COM ALUNOS DO CURSO DE PEDAGOGIA: Uma possibilidade na formação docente

PROFISSÃO DOCENTE E OS TEMAS TRANSVERSAIS: Algumas considerações

ÍNDICE 


\title{
A FORMAÇÃO CONTINUADA DOS PROFESSORES DO ATENDIMENTO EDUCACIONAL ESPECIALIZADO
}

\author{
BORGES, Angelita Salomão Muzeti \\ Doutoranda em Educação Especial - UFSCAR \\ angelita.salomao@hotmail.com \\ ANDRADE, Lucimary Bernabé Pedrosa de \\ Doutora em Serviço Social - UNESP \\ lucimarypandrade@yahoo.com.br \\ GIMENES, Priscila Alvarenga Cardoso \\ Doutora em Educação Especial - UEMG \\ priscilagimenes1@gmail.com
}

\section{INTRODUÇÃO}

As concepções de deficiência transpassaram por diferentes paradigmas nos distintos períodos históricos. Tais paradigmas, arraigados de interesses políticos, sociais e econômicos caracterizaram os atendimentos destinados às pessoas com deficiência, perpassando períodos de segregação, integração e inclusão educacional.

Nesse contexto, com as aspirações ascendentes do pós Segunda Guerra Mundial, emergem as lutas pelos direitos humanos e sociais, transformando o cenário internacional e tencionando a escolarização dos estudantes com deficiências no sistema geral de ensino. Seguindo esse prospecto, as declarações e as convenções internacionais influenciaram as políticas educacionais no Brasil, em destaque a Declaração Mundial de Educação para todos de Jomtien em 1990, a Declaração de Salamanca em 1994, e a Convenção de Guatemala em 1999.

Desta forma, a Educação Especial no Brasil segue preceitos das declarações e convenções internacionais, redefinindo os rumos da escolarização dos estudantes com deficiências através da proposição da Política Nacional de Educação Especial na Perspectiva da Educação Inclusiva (PNEE-EI) de 2008. A PNEE-El com o objetivo de oferecer a educação de qualidade a todos estudantes, definiu o público alvo da Educação Especial: estudantes com deficiências, transtornos globais do desenvolvimento e altas habilidades/superdotação; e propôs o Atendimento Educacional Especializado (AEE), descrevendo e especificando como tal atendimento deve ser realizado. 
A partir de então, alguns Decretos e Resoluções foram implantados buscando orientar o trabalho partindo da perspectiva da escola inclusiva. Também em 2008, o Ministério da Educação e Cultura (MEC) firmou a responsabilidade pelo apoio técnico e financeiro das ações do AEE. Em 2011 o Decreto 7.611/2011 estabeleceu o oferecimento da formação continuada em Língua Brasileira de Sinais (LIBRAS) e do Braille.

Assim, a formação dos professores do AEE passou a ser um tema amplamente discutido pela complexidade que exige a função e considerando que a formação inicial em Educação Especial é oferecida somente na Universidade Federal de São Carlos (UFSCAR) e na Universidade Federal de Santa Maria (UFSM). Os outros cursos oferecidos por outras universidades e faculdades condizem a especialização na temática da Educação Especial. Portanto, os cursos de Pedagogia assumem um importante papel na formação desses professores.

O Plano Nacional de Educação (PNE/2014) em sua meta 4.3 assegura a implantação das salas de recursos multifuncionais e a formação continuada desses professores nas escolas urbanas, do campo, indígenas e de comunidades quilombolas. Assim, é preciso analisar as condições que são oferecidos esses cursos, a possibilidade de aprofundamento e de aplicabilidade nos atendimentos.

Desta forma, serão abordadas neste artigo as descrições do AEE, os objetivos, conteúdos e a importante função do professor que realiza os atendimentos nas salas de recursos multifuncionais para o apoio à inclusão educacional dos estudantes público da Educação Especial, bem como a importância da fomentação da formação continuada a esses professores.

Assim, o presente artigo tem como objetivo de analisar a modalidade dos cursos de formação continuada dos professores do AEE, suas cargas horárias e os órgãos proponentes das formações, tendo em vista a complexidade destinada à função desses professores. O estudo, configurado como descritivo e qualitativo foi realizado com seis professores do AEE de uma rede municipal do sudoeste de Minas Gerais em que foram analisados os certificados dos cursos de formação continuada realizados após o ingresso à função de professor do AEE, seguindo as orientações da análise de conteúdo por categorias temáticas.

\section{AS CARACTERÍSTICAS DO ATENDIMENTO EDUCACIONAL ESPECIALIZADO (AEE)}

A PNEE-El assegurou a matrícula dos estudantes público da Educação Especial no sistema geral de ensino. Desta forma, esses estudantes 
ao realizarem a matrícula na educação comum são automaticamente matriculados no AEE oferecido no contraturno da escolarização, prioritariamente nas Salas de Recursos Multifuncionais nas escolas regulares.

O objetivo do AEE concerne em diminuir as barreiras educacionais e de acessibilidade para os estudantes público da Educação Especial matriculados na escola regular, oferecendo recursos tecnológicos e de acessibilidade, buscando complementar e/ou suplementar os conhecimentos educacionais.

Assim as Diretrizes Operacionais para o AEE propostas pelo Decreto no 7.611/2011 firmou tal atendimento como não substitutivo à escolarização comum, como apoio à inclusão desses estudantes na escola regular. Desta forma, os estudantes com deficiências computam dupla matrícula, garantindo recursos financeiros do Fundo de Manutenção e Desenvolvimento da Educação Básica e de Valorização dos Profissionais de Educação (FUNDEB).

O trabalho realizado no AEE envolve: "programa de enriquecimento curricular, o ensino de linguagens e códigos específicos de comunicação, sinalização e tecnologia assistiva" (BRASIL, 2008, p. 15). Desta forma, os conteúdos desenvolvidos são:

Língua Brasileira de Sinais - LIBRAS e LIBRAS tátil; Alfabeto digital; Tadoma; Língua Portuguesa na modalidade escrita; Sistema Braille; Orientação e mobilidade; Informática acessível; Sorobã (ábaco); Estimulação visual; Comunicação alternativa e aumentativa - CAA; Desenvolvimento de processos educativos que favoreçam a atividade cognitiva. (BRASIL, 2008, p. 27).

Assim, de acordo com a PNEE-EI, os professores do AEE devem ser formados com conhecimentos gerais da docência e específicos da Educação Especial, considerando as complexas atribuições destinadas ao trabalho das Salas de Recursos Multifuncionais abaixo descritos:

I - identificar, elaborar, produzir e organizar serviços, recursos pedagógicos, de acessibilidade e estratégias considerando as necessidades específicas dos alunos público-alvo da Educação Especial;

II - elaborar e executar plano de Atendimento Educacional Especializado, avaliando a funcionalidade e a aplicabilidade dos recursos pedagógicos e de acessibilidade;

III - organizar o tipo e o número de atendimentos aos alunos na sala de recursos multifuncionais;

IV - acompanhar a funcionalidade e a aplicabilidade dos recursos pedagógicos e de acessibilidade na sala de aula comum do ensino regular, bem como em outros ambientes da escola; $\mathrm{V}$ - estabelecer parcerias com as áreas intersetoriais na elaboração de estratégias e na disponibilização de recursos de acessibilidade; $\mathrm{VI}$ - orientar professores e famílias sobre os recursos pedagógicos e de acessibilidade utilizados pelo aluno; 


\begin{abstract}
VII - ensinar e usar a tecnologia assistiva de forma a ampliar habilidades funcionais dos alunos, promovendo autonomia e participação;

VIII - estabelecer articulação com os professores da sala de aula comum, visando à disponibilização dos serviços, dos recursos pedagógicos e de acessibilidade e das estratégias que promovem a participação dos alunos nas atividades escolares. (BRASIL, 2009)
\end{abstract}

Desta forma, é de fundamental importância que o trabalho do AEE seja articulado ao trabalho do ensino comum, tendo em vista as peculiaridades e especificidades advindas da Educação Especial. A exemplo de apoio estão o compartilhamento dos planos de trabalho no Projeto Pedagógico, a discussão do Plano do AEE, e a troca de informações e planejamento do trabalho com os estudantes, tanto nas salas de recursos quanto nas salas de aulas comuns. Porém, a articulação com o ensino comum muitas vezes é dificultada pela grande quantidade de atendimentos sob a responsabilidade dos professores do AEE.

Tendo em vista a complexidade exigida à função de professor do $A E E$, é preciso problematiza que no Brasil, as únicas universidades públicas que ofertam cursos de formação inicial em Educação Especial são a Universidade Federal de São Carlos-SP (UFSCar) e a Universidade Federal de Santa Maria-RS (UFSM). As outras universidades e faculdades do país ofertam cursos a nível de especialização nesta temática. Tal fato expõe a responsabilidade assumida pelos cursos de Pedagogia, de onde advém a maior parte dos professores do AEE.

Desta forma, a formação dos professores do AEE deve-se apresentar de forma estruturada buscando atender os desafios encontrados nos atendimentos, tendo em vista sua importância na inclusão educacional dos estudantes com deficiências. De acordo com GATTI (2010), é preciso refletir os currículos da formação docente, pela função social da escolarização, fortalecendo os valores e práticas de acordo com a vida civil.

Assim, é preciso conhecer os órgãos proponentes da formação continuada desses professores e as características dos cursos oferecidos buscando a reflexão sobre a responsabilidade advinda da função de professor do $A E E$ e apoio à inclusão dos estudantes com deficiências na rede regular de ensino.

\title{
3. OS DELINEAMENTOS DA PESQUISA
}

A presente pesquisa é parte da Dissertação de Mestrado em Planejamento e Análise de Políticas Públicas da Universidade Estadual Paulista "Júlio de Mesquita Filho" (UNESP) campus Franca. Foi realizada no 
ano de 2018 em uma rede municipal no sudoeste mineiro, caracterizando-se como descritiva e qualitativa seguindo preceitos de metodológicos de Minayo (2001) e Bardin (2004), através da análise de conteúdo. O critério para a escolha dos participantes foi por inclusão: ser professor do AEE da rede municipal estudada. Desta forma, identificou-se 6 (seis) professores do qual todos aceitaram participar da pesquisa.

Desta forma, apropriou-se da análise documental dividida em duas etapas: análise dos documentos da Secretaria Municipal de Educação referente à fomentação dos cursos de formação continuada dos professores dos AEE e a análise dos certificados dos referidos professores quanto ao cursos realizados após o ingresso à função. Contudo, a primeira etapa da análise documental referente aos documentos comprobatórios da Secretaria Municipal de Educação não foi realizada devido à ausência de tais documentos, evidenciando a falta de planejamento e sistematização da fomentação da formação continuada desses professores.

Assim, os dados obtidos dos certificados foram organizados em tabelas e posteriormente seguiram as categorias de análise temática a posteriori proposta por Bardin (2004). Desta forma, buscando resguardar aspectos de sigilo aos participantes, a pesquisa foi submetida ao Comitê de Ética e Pesquisa.

\subsection{Modalidade dos cursos de formação continuada}

Os dados obtidos evidenciaram que grande parte dos cursos realizados pelas professoras do AEE foram na modalidade presencial. Tal fato evidencia a possibilidade de troca de experiências e aproximação com 0 formador.

Gráfico 1 - Modalidade dos cursos de Formação Continuada das Professoras do AEE 


\section{Modalidade dos cursos de Formação Continuada das professoras do AEE}

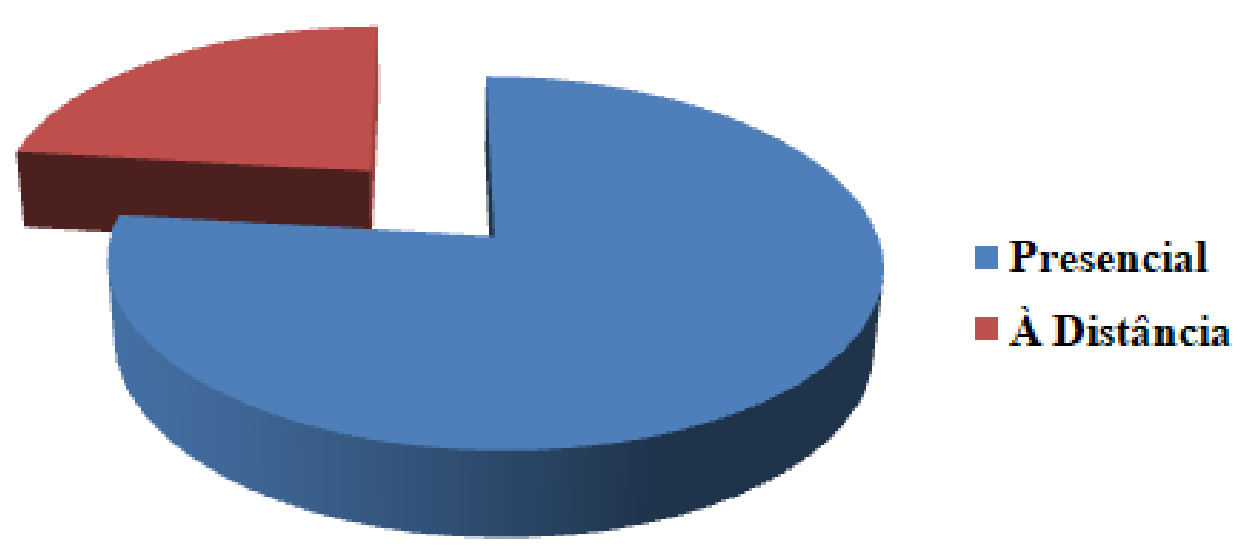

Fonte: Elaborado pela autora a partir dos dados estudados

\subsection{Carga Horária dos cursos de formação continuada por órgão proponente}

Considerando a totalidade das cargas horárias presentes nos certificados das professoras do AEE que participaram da pesquisa, a maior parte advém das empresas formadoras da área da saúde com equipes multidiciplinares, congressos e encontros on line. Porém, é preciso ressaltar que para participar desses cursos promovidos por empresas formadoras e necessário investimento financeiro.

Assim, considerando os vencimentos propostos no edital do último concurso público para professor da Educação Básica foi de $R \$ 1.423,88$, que no caso dos professores do AEE tem acréscimo de $10 \%$ por trabalharem nas salas de recursos multifuncionais, problematiza-se a dificuldade desses professores em custear a própria formação.

Salienta-se também que a Secretaria Municipal de Educação, apesar de não apresentar de forma estruturada o planejamento da formação continuada dos professores, demonstra preocupação com a formação desses professores, promovendo ações isoladas de formação. Seguidamente aparecem os cursos oferecidos pelas universidades públicas, que foram pontuais e escassos, considerando a complexidade dos atendimentos.

Assim, ressalta-se que o MEC em 2011 se responsabilizou pela formação desses professores através da Resolução 7.611 em seu artigo $5^{\circ}$ (2ํㅜ $^{\circ}$ parágrafo) item III: "formação continuada de professores, inclusive para 0 
desenvolvimento da educação bilíngüe para estudantes surdos ou com deficiência auditiva e do ensino Braille para estudantes cegos ou com baixa visão". Neste cenário, considerando os pontuais e escassos cursos oferecidos pelo governo federal através das universidades públicas contrária à responsabilidade da formação assumida pela Resolução.

Gráfico 2 - Cargas Horárias dos cursos de Formação Continuada dos Professores do AEE

\section{Cargas Horárias dos Cursos de Formação Continuada das Professoras do AEE}

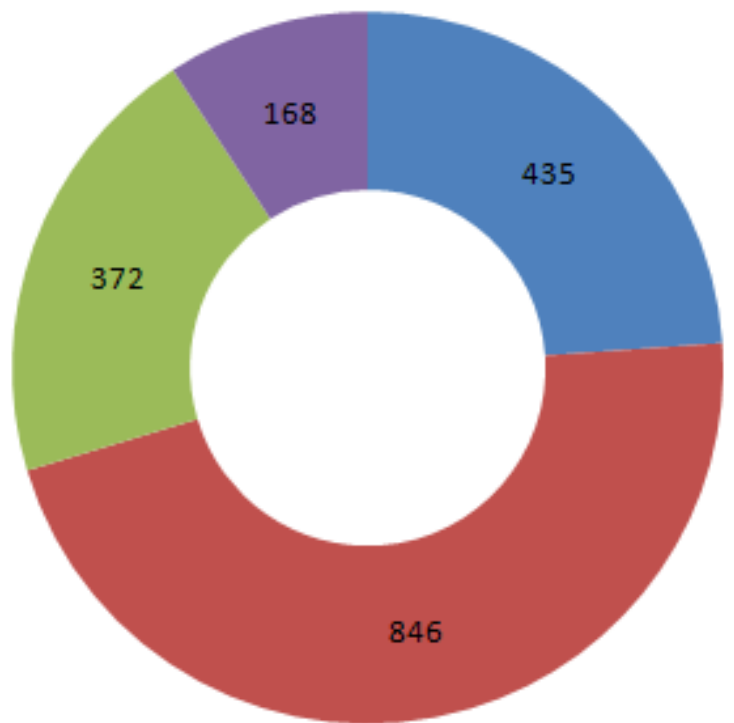
Secretaria Municipal de
Educação

- Empresas formadoras de professores

- Universidades Públicas / Governo Federal e Estadual

- Faculdades Particulares

Fonte: Elaborado pela autora a partir dos dados estudados.

Abaixo será apresentada na Figura 1 com a quantidade de cursos realizados pelas professoras do AEE por órgão proponente e carga horária.

Figura 1 - Quantidade de cursos realizados por órgão proponente e c/h

\begin{tabular}{|l|c|l|c|c|}
\hline Carga horária dos cursos & SME & $\begin{array}{l}\text { Empresas } \\
\text { Formadoras }\end{array}$ & $\begin{array}{l}\text { Universidades } \\
\text { públicas }\end{array}$ & $\begin{array}{l}\text { Faculdades } \\
\text { particulares }\end{array}$ \\
\hline Acima de $\mathbf{2 0 0}$ horas & & & & 1 \\
\hline $\begin{array}{l}\text { Acima de } \mathbf{1 0 0} \text { horas } \\
\text { Igual ou acima de }\end{array}$ & 1 & & 3 & 1 \\
\hline $\mathbf{5 0}$ horas & & & & 2 \\
\hline Abaixo de $\mathbf{5 0}$ horas & 14 & 27 & 2 & 1 \\
\hline
\end{tabular}

Fonte: Elaborado pela autora a partir dos dados estudados 
Os dados acima expostos revelam a escassez de cursos oferecidos pelas universidades públicas, além de relatarem a quantidade importante de ações destinadas às formações pela Secretaria Municipal de Educação. Também revelam que a maioria dos cursos oferecidos são abaixo de 50 horas de carga horária e oferecidos pelas empresas formadoras. Aqui problematiza-se a impossibilidade de aprofundamento teórico e a dificuldade da consonância teoria prática, devido ao curto tempo destinado à carga horária.

Desta forma, é preciso considerar os apontamentos realizados por Denari (2006) em que aponta que os modelos aligeirados de formação ente 30 e 180 horas com palestras sem avaliação adequada são oferecidos em caráter emergencial e sem tempo suficiente para o aprofundamento dos conteúdos (DENARI; SIGOLO, 2016).

\section{CONSIDERAÇÕES FINAIS}

Considerando que a maioria dos professores do AEE são formados pelos cursos de Pedagogia, é preciso atentar à organização e sistematização da formação continuada específica na área da Educação Especial. Tal fato preocupa por revelar que o compromisso assumido pelo Governo Federal através do Decreto № 7611 de 2011 não está sendo cumprido.

Quando verificados os certificados dos professores do AEE quanto à formação continuada após 0 ingresso à função na sala de recursos multifuncionais, observou-se que a maioria foram cursados presencialmente, fato positivo considerando a possibilidade de troca de informações e experiências e esclarecimentos de dúvidas para a aplicabilidade prática nos atendimentos.

Desta forma, os dados também apontam que a Secretaria Municipal de Educação tem se esforçado para atender emergencialmente essa demanda de formação. O desenvolvimento da pesquisa revelou que os professores do $A E E$ buscam formação em diferentes órgãos proponentes tendo em vista a escassez do oferecimento dos cursos pelo Governo Federal e Estadual. Assim, os professores do AEE desta rede municipal estudada demonstraram anseio à busca pelos cursos de formação continuada em vários locais, como as Empresas Formadoras advindas da área da saúde, equipes multidisciplinares, congressos e encontros on line.

Também é preciso ressaltar que a maioria dos cursos oferecidos pelas empresas formadoras, compõem cargas horárias mínimas, dificultando o aprofundamento de metodologias para a aplicabilidade dos atendimentos nas salas de recursos multifuncionais. 


\section{REFERENCIAS}

BARDIN, L. Análise de Conteúdo. 3. ed. Lisboa, Portugal: Edições 70, 2004.

BRASIL. Declaração de Salamanca e linha de ação sobre necessidades educativas especiais. Brasília: UNESCO, 1994.

BRASIL. Decreto n. 3.956, de 8 de outubro de 2001. Promulga a Convenção Interamericana para eliminação de todas as formas de discriminação contra as pessoas portadoras de deficiência, Guatemala: 2001.

BRASIL. Lei no 11.494, de 20 de junho de 2007. Fundo de Manutenção e Desenvolvimento da Educação Básica e Valorização dos Profissionais da Educação. Disponível em: <http://portal.mec.gov.br/fundeb-sp-1090794249>. Acesso em: 8 jul. 2019.

BRASIL. PARECER CNE/CEB №: 13/2009 Ministério da Educação. Diretrizes Operacionais para o Atendimento Educacional Especializado na Educação Básica. Disponível em: < http://portal.mec.gov.br/dmdocuments/pceb013 09 homolog.pdf >. Acesso em: 12 jul. 2019.

BRASIL. Conferência de Educação Mundial para todos. Jomtien, 1990. Disponível em:< https://www.unicef.org/brazil/pt/resources 10230.htm>. Acesso em: 12 jul. 2019.

BRASIL. Decreto n.7.611 de novembro de 2011. Dispõe sobre a educação especial, o atendimento educacional especializado e dá outras providências. Diário Oficial da União, Poder Executivo, Brasília, DF, 17 nov. 2011. p.1. Disponível em: <http://www.planalto.gov.br/ccivil 03/ ato20112014/2011/decreto/d7611.htm>. Acesso em: 14 jul. 2019.

BRASIL. Ministério da Educação. Secretaria de Educação Especial. Política Nacional de Educação Especial na Perspectiva da Educação Inclusiva. Brasília, DF: Secretaria de Educação Especial, 2008. Disponível em: $<$ http://portal.mec.gov.br/seesp/arquivos/pdf/politica.pdf >. Acesso em: 14 jul. 2019.

BRASIL. Lei no 13.005 , de 25 de junho de 2014. Plano Nacional da Educação. Disponível em:<http://www.observatoriodopne.org.br/uploads/reference/file/439/documento -referencia.pdf. >. Acesso em: 2 jul. 2019.

DENARI, F. E. SIGOLO, S. R. R. L. Formação dos professores em direção à Educação Inclusiva no Brasil: Dilemas atuais. p. 15-31. Marília/Oficina Universitária São Paulo/Cultura Acadêmica, 2016. 
GATTI, B. A. Formação de professores no Brasil: características e problemas. Educ. Soc., Campinas, v. 31, n. 113, p. 1355-1379, out.-dez. 2010. Disponível em: <http://www.scielo.br/pdf/es/v31n113/16.pdf.>. Acesso em: 5 jul. 2019.

MINAYO, M. C. de S. Pesquisa Social. Teoria, método e criatividade. 18. ed. Petrópolis: Vozes, 2001. 


\title{
A FORMAÇÃO DE PROFESSORES NO CURSO DE PEDAGOGIA E O USO DE METODOLOGIAS ATIVAS: Alunos protagonistas, docentes qualificados
}

\author{
ARAGÃO, Amanda Silva \\ Mestre em Educação - UFSCar \\ Docente - Faculdade Anhanguera \\ CAROTA, Filipe Pimenta \\ Mestre - UNESP \\ Docente - Faculdade Anhanguera
}

\section{INTRODUÇÃO E PERCURSO METODOLÓGICO}

O objetivo geral do presente trabalho é direcionar os leitores quanto a prática do Team-based learning (TBL) e a formação de professores no curso de Pedagogia em uma Instituição de Ensino Superior no interior do Estado de São Paulo. Desenvolvida por Larry Michaelsen nos anos de 1970 nos Estados Unidos, essa estratégia chegou ao Brasil em cursos universitários da área da saúde e, atualmente, tem se estendido em várias áreas da formação de novos profissionais.

A metodologia utilizada no desenvolvimento desse trabalho é realizada em uma abordagem qualitativa dividida em dois passos: revisão bibliografia e coleta de dados. O primeiro passo foi realizado nas bases de dados acadêmicas analisando título, resumo, palavras - chaves, área do conhecimento. $O$ segundo passo foi realizado na instituição de ensino junto ao Plano de Ensino do curso e das disciplinas, uma vez que a IES analisada organiza a formação de professores em três momentos: pré-aula, aula e pósaula

Situado no campo da pesquisa qualitativa, esse trabalho tem o objetivo de atribuir um significado na formação de professores a partir de abordagens utilizando metodologias ativas de aprendizado. Para tanto, a metodologia empregada ao longo da construção do texto, permite analisar 0 desenvolvimento do curso de pedagogia na instituição analisada e elencar os conceitos de aprendizagem desenvolvidos pela instituição. A prática assume 0 espaço de objeto de estudo.

Ao analisar o artigo de Hartmut Gunther (2006), há um entendimento quanto a pesquisa qualitativa relacionado a compreensão das relações complexas. Em sua definição, o autor aponta que esse método de pesquisa está baseado em textos, e analises que são realizadas com técnicas analíticas e interpretadas hermeneuticamente. 


\begin{abstract}
Ao invés de utilizar instrumentos e procedimentos padronizados, a pesquisa qualitativa considera cada problema objeto de uma pesquisa específica para a qual são necessários instrumentos e procedimentos específicos. Tal postura requer, portanto, maior cuidado na descrição de todos os passos de pesquisa: a) delineamento, b) coleta de dados, c) transcrição, d) preparação dos mesmos para sua análise específica. (GUNHTHE, 2006, p.204).
\end{abstract}

Dois passos importantes quanto a pesquisa qualitativa são o desenvolvimento de uma pesquisa bibliográfica e análise documental. Ao realizar a análise de documentos é possível identificar os conceitos de aprendizagem encontrados no plano de ensino da instituição analisada. A coleta dos dados é realizada a luz de uma revisão bibliográfica que fundamenta a formação de professores na literatura acadêmica.

Os cuidados referentes as referências bibliográficas são empregados utilizando o que a literatura denomina como "estado da arte", uma vez que essa abordagem aparece com grande destaque nos debates acadêmicos que utilizam a revisão bibliográfica. Alguns caminhos utilizados para a seleção são: título, resumo, introdução, metodologia e conclusão. Ao analisar esses itens, é possível que o pesquisador filtre os trabalhos que tratavam sobre o objeto de sua pesquisa.

Ferreira, 20002, apontou que o "estado da arte" possuí caráter bibliográfico, pois tem como desafios mapear a discussão de um determinado campo do conhecimento na busca de responder aspectos e dimensões que se encontram destacados e privilegiados. Utilizando categorias de estudo dos artigos produzidos, a investigação lança esclarecimentos ao conjunto de ideias de uma área do saber científico ou dos fenômenos por ela analisados.

Agma Juci Traina e Caetano Trina Jr., elencaram alguns critérios que são necessários ao realizar uma pesquisa bibliográfica. Na obra "Como fazer uma pesquisa bibliográfica", os próprios autores elencam os passos que são utilizados para a pesquisa. O primeiro passo é a identificação dos conceitos, das ferramentas e técnicas utilizadas na construção do artigo analisado. O segundo passo é tentar identificar as técnicas e recursos que os autores utilizaram ou tenham sido citados em trabalhos semelhantes. $O$ terceiro se constitui em identificar as necessidades, resultados e as situações que justificaram o desenvolvimento da pesquisa.

Porém, alguns cuidados e desafios são colocados no percurso metodológico ao se realizar os dois passos apontados, sendo a análise documental e a pesquisa bibliográfica. Para explicitar melhor tais desafios e cuidados utiliza-se do artigo de Claudinei José Gomes Campos e suas considerações como base da metodologia qualitativa empregada na pesquisa. 
Sobre os desafios encontrados em uma pesquisa, no que se refere à análise de conteúdo, o pesquisador deve lhe dar com maneira clara em relação aos conteúdos descritos nos documentos ou nas pesquisas bibliográficas que são realizadas, considerando este um desafio eminente. Para tanto, a pesquisa requer um especial cuidado metodológico, como destaca

Desta maneira, a análise de conteúdo não deve ser extremamente vinculada ao texto ou a técnica, num formalismo excessivo, que prejudique a criatividade e a capacidade intuitiva do pesquisador, por conseguinte, nem tão subjetiva, levando-se a impor a suas próprias ideias ou valores, no qual o texto passe a funcionar meramente como confirmador dessas. (CAMPOS, 2004, p. 613).

A partir do exposto, passamos a identificar a prática do TBL Team Based Lerning como ferramenta de atuação no Ensino Superior, utilizando como referência a produção bibliográfica encontrada. No próximo item desse trabalho, serão apontadas algumas questões quanto a formão de professores na literatura acadêmica e por fim, uma exposição das metodologias utilizadas na formação de professores no objeto de estudo dessa pesquisa.

\section{O TBL - Team Based Learning como ferramenta de atuação no Ensino Superior}

A educação é comumente pauta das agendas políticas nacionais como um dos maiores desafios a serem superados no século XIX. Problemas como infraestrutura, currículo, avaliação e formação de professores podem ser encontrados em literaturas, congresso ou pautas jornalísticas por todo o país. No que se refere as práticas de formação de professores, esse trabalho se volta a entender a construção do conhecimento na universidade dentro do curso de pedagogia visando o aperfeiçoamento e a busca de alternativas diferenciadas na construção do saber. Não podemos mais tratar os professores apenas como um transmissor do conhecimento ou memorização, mas entender a educação como uma nova dinâmica na relação aluno - professor.

A fundamentação teórica para realização da pesquisa é baseada na obra de Greyson Alberto Rech (2016) quanto ao uso do TBL na formação de docentes na área de Ciências Exatas. Tendo como problema central de sua pesquisa, o seu trabalho desenvolve uma ênfase sobre o curso de formação inicial com 18 professores nas aulas de matemática na região de Concórdia SC. Seu estudo identificou as práticas pedagógicas dos professores a partir dos pressupostos de metodologias ativas, como o TBL. Quanto ao papel da educação, salienta que:

É importante conceber que a educação é um conjunto de processos de ensinar e de aprender e está presente em todos 
os grupos sociais. Ela é responsável pela manutenção de modos culturais que refletem ações, estados e movimentos de cada sociedade, podendo ser formal, quando tratada em espaços escolarizados, ou informal, quando ocorre no cotidiano de cada indivíduo. (RECH, 2016, p.13)

$\mathrm{Na}$ educação, o emprego de uma metodologia baseada em resolução de problemas é uma forma de construção do conhecimento que se mostra eficaz pois apresenta situações abertas e que despertar no aluno uma atitude ativa na construção da resolução e busca de uma resposta. Pozo (1998) afirmou que a resolução de problemas na educação constitui um modelo de ensino que promove nos alunos o uso de conhecimentos disponíveis para dar respostas a diferentes situações que são apresentadas, ou seja, contrário aos métodos que são baseados em dar uma resposta pronta. Cabe ao processo de formação na universidade a produção do conhecimento por meio da reflexão atrelada a participação.

\begin{abstract}
Uma forte característica do mundo atual é a importância do conhecimento e da informação frente aos outros fatores de produção. Nesse contexto, há uma extrema necessidade de trabalhos em grupo, um processo ativo de troca e produção de conhecimento, e não somente de difusão de informações, um conhecimento apropriado e condizente com cada realidade. Para tanto, é preciso desenvolver nas salas de aula do ensino superior, um ambiente de reflexão e discussão, em que ocorra a participação de todos. (RECH, 2016, p.49)
\end{abstract}

Em meio a nova dinâmica do mundo atual, as salas de aula das universidades se mostram cada vez mais formadas por um grande grupo de alunos. A expansão do Ensino Superior e do acesso a essa rede trouxeram a necessidade de novos modelos de ensino. Nesse sentido, quando o TBL foi desenvolvido constitui-se como uma ferramenta capaz de envolver um grupo grande de alunos, de forma ativa, na formação universitária.

No artigo "Aprendizagem baseada em equipes: da teoria à prática”, o TBL é descrito como ferramenta capaz de criar oportunidades no trabalho com grupos de podem ir de 5 a 7 alunos, ainda que a turma seja formada por um grupo de aproximadamente 100 alunos. Outro fator importante de destaque no texto é que o TBL pode ser utilizado para complementar o curso, e não necessariamente para substituição de outras práticas que são realizadas. É possível conciliar o TBL com outras metodologias. Em relação aos componentes e características gerais do TBL, o quadro a seguir oferece uma dimensão referente a descrição, vantagens, desvantagens e resultados, além de um olhar sobre a atuação do docente e do discente no uso do TBL. 


\begin{tabular}{|c|c|}
\hline \multicolumn{2}{|r|}{$\begin{array}{l}\text { QUADIO } 1 \\
\text { Componentes e caracteristicas gerais do Team-Based Learning (TBL) }\end{array}$} \\
\hline Componentes & Caracteristicas gerais \\
\hline Descriglo & 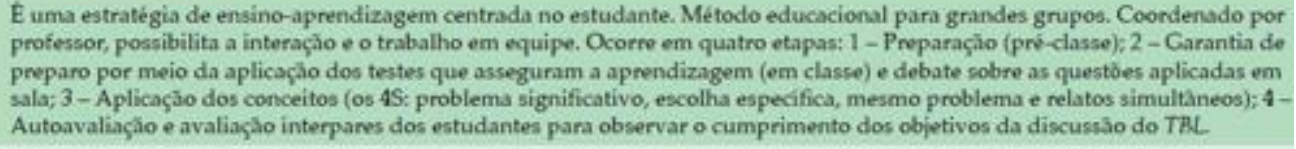 \\
\hline Instituigho & 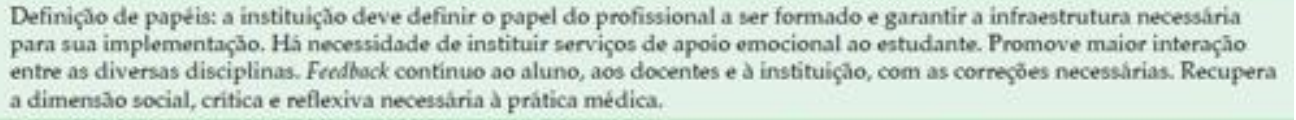 \\
\hline Docente. & $\begin{array}{l}\text { Interaça interage com os estudantes, atuando apenas quando é necessário. Assume papel de facilitador do aprendizado. } \\
\text { Cabe ao professor mediar estimulos e oportunidades para que todos os estudantes possam desenvolver habilidades e atitudes } \\
\text { de representatividade, autonomia e comunicaçăo. Em geral, os docentes têm mais trabalho na fase prévia à execuçâo do TBL. }\end{array}$ \\
\hline Discente & $\begin{array}{l}\text { Ativo: o foco é desviado para que seja responsável pelo seu próprio ensino. Quando bem orientado, passa a exercer atitude } \\
\text { critica e construtiva. Desenvolve a inteligência relacional, autonomia e maior responsabilidade sobre o autoaprendizado. O } \\
\text { trabalho em grupos ou equipes estimula a organizaglo e o mútuo comprometimento entre os estudantes. }\end{array}$ \\
\hline Vantagens & $\begin{array}{l}\text { Individualizar as necessidades dos eatudantes ao se trabalhar com grupos pequenos, facilitando a interagho aluno-professor. } \\
\text { O respeito à singularidade e a habilidade de lidar com o outro permitem a aquisigto progressiva de autonomia e maturidade. }\end{array}$ \\
\hline Desvantagens & $\begin{array}{l}\text { Manter treinamento e capacitaçào docente continuos. Consome enorme tempo docente de preparo, aplicação e avaliaçăo da } \\
\text { atividade. Requer o trabalho com pequenos grupos para que seja efetivo. Requer o sacrificio de se transmitir todo o contéado, } \\
\text { sendo necessário selecionar o "conteúdo essencial" que será trabalhado exaustivamente. }\end{array}$ \\
\hline Resultados & 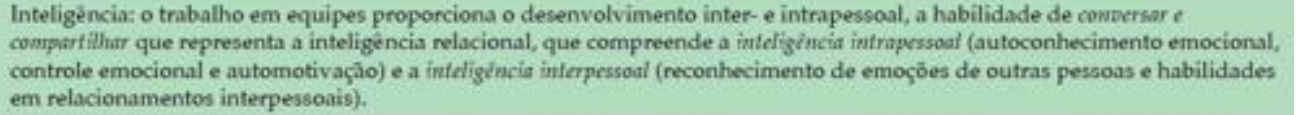 \\
\hline
\end{tabular}

Para saber mais acesse: https://www.teambasedlearning.org/ - Fonte: Adaptado de Bollela et al.5; Souza et al.6.

Esse modelo é descrito por RECH (2016) em suas fases: a primeira delas é a da preparação, na qual o aluno tem acesso ao conteúdo que será debatido em sala de aula. Em seguida, é realizado uma discussão sobre questões que oferecem uma garantia do preparo. A segunda é a aplicação dos conceitos, onde os alunos recorrem a base teórica na tentativa de buscar resposta a questões que foram propostas. Essas fases estão melhor representadas no quadro a seguir:

Figura 2 - Esquema de aplicação do Team Based Learning

\begin{tabular}{|c|c|c|c|c|c|}
\hline & \multirow{2}{*}{$\begin{array}{l}\text { Preparoç,ồo } \\
\text { (Prétaula) }\end{array}$} & \multicolumn{2}{|c|}{ Garantia de Aptidão } & \multicolumn{2}{|c|}{ Aplicação dos Conceitos do Curso } \\
\hline & & \multicolumn{2}{|c|}{1 hora + ou - } & \multicolumn{2}{|c|}{ De alguns minutos a várias horas (Integrativo) } \\
\hline \multirow[t]{2}{*}{$\begin{array}{l}\text { 1. Estudo } \\
\text { individual }\end{array}$} & \multirow[t]{2}{*}{$\begin{array}{r}2.7 \\
\text { Indi }\end{array}$} & $\begin{array}{l}\text { leste } \\
\text { vidual }\end{array}$ & \multicolumn{2}{|c|}{$\begin{array}{l}\text { 5. Tutorial do } \\
\text { Professor }\end{array}$} & \multirow{2}{*}{$\begin{array}{l}\text { 6. Aplicação/Atividades e } \\
\text { Problemas focados em } \\
\text { desenvolvimento do } \\
\text { pensamento critico }\end{array}$} \\
\hline & & $\begin{array}{l}\text { 3. } \mathrm{Te} \\
\text { em Gr }\end{array}$ & \multicolumn{2}{|c|}{$\begin{array}{l}\text { 4. Contestaçäo por } \\
\text { escrito (equipes) }\end{array}$} & \\
\hline
\end{tabular}

Fonte: Michaelsen, 2013 (apud RECH, 2016, p.54)

\section{A FORMAÇÃO DE PROFESSORES: Revisão literária}

A redemocratização brasileira no final dos anos de $1980-1990$ abriu espaço para temas de interesse social. A educação, como um desses direitos, se constitui como uma pauta do processo de aberturas políticas, 
ideológicas, liberdade de imprensa, fim da censura e nesse sentido, a necessidade de se pensar a formação de professores para a formação de um novo cidadão.

A partir das obras de Nóvoa (1992), Rios (2009) e Gatti (2017) é possível analisar as dimensões acadêmicas, o percurso histórico e o desenvolvimento pessoal/profissional de novos docentes. Essas obras tomam como referência as diretrizes educacionais para a formação de professores no Brasil.

A formação de professores, de acordo com Nóvoa (1992), iniciase no Brasil no final do século XIX, após o mesmo romper com as características religiosas que envolveram as primeiras práticas educacionais no nosso país e, passar ao Estado a tutela do ensino. Os cursos denominados Normais tomaram espaço no cenário educacional brasileiro nesta época, e predominaram na formação docente até a década de 90, onde, a partir da Lei 9394/96 ficou instituída a necessidade de cursos superiores para atuação em sala de aula.

Gatti (2010) apresenta as modificações ocorridas a partir do século $X X$, uma vez que se havia a preocupação com a formação de professores para o ensino "secundário" (correspondendo aos atuais anos finais do ensino fundamental e ao ensino médio), em cursos regulares e específicos. Segundo a mesma autora, essa modalidade era atendida por profissionais liberais ou autodidatas, uma vez que o número de escolas secundárias e alunos nesta modalidade era bem pequeno.

Somente no final dos anos de 1930, nas poucas Universidades existentes, os cursos de bacharéis incluíram um ano de formação pedagógica, modelo conhecido como " $3+1$ ", para atender essa demanda de docentes para o ensino secundário. Neste contexto, o curso de Pedagogia, regulamentado em 1939, também foi modificado com a inclusão, ao título de especialista em educação (bacharel), de um ano de formação pedagógica, para a atuação em sala aula nos cursos Normais e níveis secundários (GATTI, 2010).

Gatti (2010) destaca que somente em 1996 (Lei n. 9.294/96 - Lei de Diretrizes e Bases da Educação Nacional) houveram modificações efetivas na formação docente, a partir da exigência dos cursos superiores. No entanto, as licenciaturas, modalidade majoritária nesta época para a formação de professores, historicamente consolidou a ideia de oferecimento de formação com foco na área disciplinar específica, com pequeno espaço para a formação pedagógica, o que reforçou o distanciamento entre conhecimento específico e prática pedagógica.

Quanto aos cursos de graduação em Pedagogia as mudanças aconteceram somente em 2006, com a ampliação de propostas curriculares 
para a formação de professores. Essa licenciatura passa a ter amplas atribuições, o que aumenta a complexidade curricular e os desafios na constituição deste profissional.

Infelizmente, ainda como destaca Gatti (2010), um currículo complexo gerou a fragmentação na formação, e no Brasil, sentiu-se a ausência de um instituto próprio, formador desses profissionais, com uma base comum formativa, onde uma formação ampla pudesse ser discutida e aplicada.

Neste modelo de formação, o professor polivalente foi historicamente sendo desvalorizado, dificultando a construção das práticas pedagógicas eficientes à realidade cultural do aluno, uma vez que somente o conhecimento específico se destacava como o responsável pela aprendizagem.

Nesse sentido, Rios (2009) destaca que o conhecimento pedagógico vai se dissolvendo no "fazer pedagogia", banalizando o conhecimento pedagógico e contribuindo para práticas cada vez mais desconexas. A identidade que se cria, neste contexto, é de um profissional que reproduz metodologias incoerentes à sua realidade. Os saberes acumulados ao longo de sua formação vão se distanciando do que se encontrará em ambiente escolar.

Dessa forma, os desafios para uma prática consciente contribuem para ampliar as lacunas entre teoria e prática. Segundo Gatti (2017), os desafios enfrentados em sala de aula se dão pelas mudanças sociais contemporâneas, uma vez que a complexidade das relações cotidianas exige uma prática que não generalize, nem apresente um olha trivial para a diversidade entre sujeitos e suas culturas. É preciso ter clara a concepção de que tipo de sujeito se quer formar, mediante ao universo cultural, educacional e político na qual o país se encontra, uma vez que as práticas efetivas só acontecerão neste cenário.

A autora ainda destaca os desafios de se educar as novas gerações mediante a todas as modificações que as mesmas têm apresentado. Ela destaca que uma educação efetiva só acontecerá a partir de uma comunicação eficiente, que faça sentido à realidade do aluno. Nesta perspectiva, torna-se indispensável aproximar os discursos vivenciados academicamente da prática que será realizada cotidianamente. Aproximar as discussões realizadas no Ensino Superior do que acontece na educação básica é uma maneira de se diminuir as lacunas entre teoria e prática e isso se torna uma realidade a partir de novas metodologias de ensino.

A emergência de novas orientações formativas para o magistério, da parte do Conselho Nacional de Educação - CNE -, vem de encontro à necessidade de se criarem condições para mudanças nessa formação, no reconhecimento de suas limitações atuais, como está 
bem expresso no Parecer CNE/CP n. 2/2015 (BRASIL, 2015a) (Gatti, 2017, p.5).

Assim, somente um profissional crítico e consciente de sua prática terá elementos para enfrentar, cotidianamente um cenário em constante mudança. Para que a formação inicial contribua para este processo novas formas de ensinar e aprender precisam ser apresentadas aos futuros educadores e as metodologias ativas podem se tornar uma ferramenta essencial neste caminho.

\section{METODOLOGIAS ATIVAS NA FORMAÇÃO DE PROFESSORES}

$\mathrm{Na}$ instituição de ensino analisada nesse trabalho, é possível identificar junto ao Plano de Ensino do curso de Pedagogia que o modelo acadêmico de formação dos alunos se situa em três momentos: pré-aula, aula e pós-aula. Para romper com uma metodologia tradicional, esses três momentos visam abordar na formação universitária o uso de metodologias ativas, a garanti do preparo do aluno para o que será desenvolvido em classe, bem como a sistematização do que foi aprendido no pós - aula.

Sendo a Anhanguera - Sertãozinho uma instituição de Ensino Superior da rede privada, essa faculdade buscou adaptar o seu projeto de curso a um novo mundo marcado por: urbanização, uma rápida expansão do sistema escolar, novas demandas e hábitos de uma cidade que se industrializou em torno do setor sucroenergético. Priorizando o protagonismo do aluno no seu processo de aprendizagem, a abordagem de ensino ocorre baseada na: autonomia, senso crítico, capacidade de resolver conflitos e tomada de decisões.

A opção realizada no modelo acadêmico da instituição é a sala de aula invertida aliada a Aprendizagem Baseada em Problemas. A desconstrução do professor como transmissor do conhecimento permite que alunos tenham maior controle sobre o tempo de estudo, possas refletir e conhecer as práticas de vida profissional e sugiram novas soluções aos problemas debatidos.

Essa modificação na relação aluno - professor é fundamental no que se refere as transformações vivenciadas no mundo atual. As novas tecnologias estão transformando a forma como os indivíduos interagem ou com a qual se organiza a sociedade. Podem definir, nas palavras de Manuel Castells, como "sociedades em rede", ou seja, uma sociedade na qual a articulação entre os movimentos sociais, cidadão e indivíduos ocorre em um modelo de organização centrado nas relações estabelecidas entre os sujeitos. Essas relações:

Começam em contextos específicos, por motivos próprios, constituem suas próprias redes e constroem seu espaço 
público ao ocupar o espaço urbano e se conectar às redes da internet. Mas também são globais, pois estão conectados com o mundo inteiro, aprendem com outras experiências e, de fato, muitas vezes são estimulados por essas experiências a se envolverem em sua própria mobilização. (CASTELLS, 2013, p.161)

Nesse sentido, os alunos do curso de pedagogia têm como ponto de partida uma discussão de uma situação - problema relacionada ao cotidiano profissional com a finalidade de mobilizar as habilidades que serão necessárias na carreira dentro do mercado de trabalho. O professor é um mediador do debate com os alunos, no momento pela qual, a aula presencial não tem o foco de transmitir os conceitos, mas sim, de fortalecer a resolução do problema.

No modelo acadêmico adotado percebe-se que o ensino por competência faz parte da estrutura do plano de ensino de todas as disciplinas do curso. É elemento central da construção do plano de ensino, além dos objetivos, conteúdos e referências, que sejam elencados as competências que serão trabalhadas naquela disciplina. Além disso, a formação deve contemplar a personalização do ensino, uma educação inclusiva e a formação para empregabilidade.

Para fortalecer a discussão pedagógica no ensino de competências, os alunos tem acesso a uma plataforma virtual denominada de Kroton Learning System (KLS), no qual, de forma inovadora, se apresentam metodologias ativas que articulam a teoria e a prática de modo a tornar significativo o processo de aprendizagem. No decorre dessa metodologia, os conteúdos são adaptados às realidades e às experiências dos alunos.

Todas as disciplinas que os alunos encontram no KLS estão planejadas de acordo com as demandas da sociedade e do mercado de trabalho. As competências e técnicas estão descritas nos componentes curriculares, considerando as exigências da área de atuação de cada aluno, no caso desse trabalho, do curso de pedagogia. Com essa abordagem, espera-se efetivar a empregabilidade do aluno.

No ensino dessas competências o aluno desenvolve sua capacidade de solucionar, de forma eficaz, uma situação - problema, mobilizando todos seus recursos cognitivos. Quando a execução da tarefa acontece, é demandado por parte do corpo de alunos uma postura reflexiva. Aqui, a aprendizagem não está atrelada apenas nos conteúdos, mas sim, na gestão desses conteúdos com uma finalidade.

Quanto ao ensino adaptativo, os conteúdos educacionais são dispostos no KLS por meio de livros, webaulas, exercícios, e permite uma análise por parte do aluno de uma grande rede de informações. Na trajetória acadêmica 0 aluno tem acesso aos dados necessários para superar as 
dificuldades apresentadas em sua formação. A tecnologia contribui para personalizar o ensino, pois textos e conteúdos atendem as demandas dos alunos conforme avançam seus estudos no AVA - Ambiente Virtual de Aprendizagem. Esse ambiente, complementa a sala de aula.

Além disso, as disciplinas apresentam uma abordagem prática, onde os alunos são desafiados a trabalhar os conceitos teóricos em atividades que reproduzam a realidade de sala de aula. Dessa forma, eles aprendem de maneira crítica, coerente e vão criando um repertório de ações para quando estiverem atuando profissionalmente.

\section{CONSIDERAÇÕES FINAIS}

Os resultados obtidos na pesquisa permitem concluir que, tendo em vista a crescente expansão da formação de professores nas Instituições de Ensino Superior do sistema privado, o uso de metodologias ativas na formação de professores tem valorizado o papel do estudante no processo de ensino e aprendizagem, colocando-o como protagonista na construção do próprio conhecimento possibilitando profissionais mais preparados para o uso de metodologias ativas em sua prática docente.

Destaca-se ainda alguns elementos que são necessários na construção do processo de ensino e aprendizagem, tendo como consequência a própria ação do processo docente: o primeiro, que o uso de diferentes abordagens torna a aula mais prazerosa, bem como, significativa. Em seguida, que realizar atividades, jogos e propor desafios são formas de construir competências necessárias para a formação discente quanto na atuação docente.

Quanto a aprendizagem de adultos, o TBL se mostra como uma ferramenta pedagógica capaz de despertar a construção do conhecimento de forma individual e coletiva. É uma técnica importante no que diz respeito a valorização de responsabilidades individuais, bem como, uma forma de motivação. Esse último ponto é fundamental na instituição de Ensino Superior da rede privada na qual muitos alunos possuem dupla jornada trabalho-estudo. Tornar a formação de novos docentes relevante é uma forma de capacitar profissionais para atuação enquanto professores frente aos novos desafios que o mundo constrói.

\section{REFERÊNCIAS}

BOLLELA, Valdes Roberto. SENGER, Maria Helena. TOURINHO, Francis. S. V; AMARAL, Eliana. Aprendizagem Baseada em equipes: da teoria à prática. In: Medicina. v.47, Ribeirão Preto, 2014. p.293-300 
CAMPOS, Claudinei José Gomes. Método de Análise de Conteúdo: ferramentas para a análise de dados qualitativos no campo da saúde. In. Rev. Bras. Enferm. Brasilia (DF) Set/Out de 2004

CAMPOS, Claudinei José Gomes; TURATO, Egberto Ribeiro. Análise de conteúdo em pesquisas que utilizam metodologia clínico-qualitativa: aplicação e perspectivas. In: Rev. Latino-Am. Enfermagem. vol.17, n.2, 2009, p.259-264

CASTELLS, Manuel. Redes de Indignação e Esperança. Rio de Janeiro: Zahar, 2013

FERREIRA, Norma Sandra de Almeida. As pesquisas denominadas "estado da arte". In. Revista Educação \& Sociedade, ano XXIII, nº 79, Agosto/2002

FILHO, M.B.Lourenço. Organização e administração escolar. São Paulo: Melhoramentos, 1972.

GATTI, Bernadete A. Didática e formação de professor: provocações. In: Caderno de Pesquisa v.47.n.166. (2017) p.1150-1164.

GATTI, Bernadete A. Formação de Professores no Brasil: Características e Problemas. In: Educação e Sociedade. v.31. n.113. Out-Dez. Campinas, 2010. P.1355-1379

GUNTHER, Hartmut. Pesquisa Qualitativa Versus Pesquisa Quantitativa: Esta é a questão?. In: Psicologia, Teoria e Pesquisa. Maio-Ago 2006, Vol 22 n.22, pp.201-210.

MANZINI, E.J. Entrevista semi-estruturada: análise de objetivos e de roteiros. In: SEMINÁRIO INTERNACIONAL SOBRE PESQUISA E ESTUDOS QUALITATIVOS, 2, 2004, Bauru. A pesquisa qualitativa em debate. Anais... Bauru: USC, 2004. CD-ROOM. ISBN:85-98623-01-6. 10p.

NÓVOA, António, coord. - Formação de professores e profissão docente. In: Os professores e a sua formação. Dom Quixote, Lisboa 1992. p. 13-33

OLIVEIRA, Bruno Luciano C. Alves de. LIMA, Sara F. RODRIGUES, Lívia dos Santos. PEREIRA JUNIOR, Gerson Alves. Team- Based Learning como forma de aprendizagem colaborativa e sala de aula invertida com centralidade nos Estudantes no Processo de ensino-aprendizagem. In: Revista Brasileira de Educação Médica. Brasil, 2018. p.86-95

POZO J. I. A solução de problemas: aprender a resolver, resolver para aprender. Porto Alegre: Artmed, 1998.

RIOS, Terezinha Azerêdo. Ética na docência universitária: a caminho de uma universidade pedagógica. UNINOVE. Sáo Paulo, 2009. 
RECH, Greyson Alberto. Metodologias Ativas na formação continuada de professores de Matemática. Dissertação de Mestrado. UNIVATES. Lajeado, 2016. $176 \mathrm{p}$.

SEVERINO. Antonio Joaquim. Metodologia do trabalho científico. São Paulo Cortez, 1993. 14.ed.

TRAINA, Agma Juci Machado; TRAINA JR, Caetano. Como fazer pesquisa bibliográfica. SBC Horizontes, v. 2, n. 2, p. 30-35, 2009.

VENTURA, Magda Maria. O estudo de caso como modalidade de pesquisa. Revista da Sociedade de Cardiologia do Estado do Rio de Janeiro, Rio de Janeiro, v. 20, n. 5, p. 383-386, set./out. 2007. 


\title{
A TUTORIA A DISTÂNCIA: Sua função e suas responsabilidades
}

\author{
SATAKA, Mayara Mayumi \\ Doutoranda em Linguística e Língua Portuguesa - UNESP/FclAr \\ mayarasataka@gmail.com \\ SILVA, Matheus Felipe \\ Doutorando em Ciências Sociais - UNESP/FclAr \\ matheusfsilva.90@gmail.com
}

\section{INTRODUÇÃO}

As transformações sucedidas na sociedade de informação e comunicação vêm tendo desdobramentos em diversos campos de atuação das Ciências Humanas, uma vez que tais transformações constituem e mudam tanto os fenômenos estudados quanto o fazer científico. Dentre tantas áreas, as Tecnologias Digitais de Informação e Comunicação (doravante TDICs) ganha destaque na Educação, pois se relaciona com o esforço de tornar os processos de ensino/aprendizagem mais significativos na vida de professores e alunos.

Além disso, nos últimos anos pudemos presenciar uma ampliação dos cursos de graduação, pós-graduação e especialização na modalidade à distância, protagonizada, nos dias atuais, pelas TDICs, já que grande parte do processo de ensino/aprendizagem ocorre virtualmente. A oferta dessa modalidade educacional tem sucedido por instituições tanto públicas quanto privadas. No que tange a EaD na Educação Pública, temos como exemplo a Universidade Aberta do Brasil (UAB), que é um programa fomentado pelo Governo Federal que estimula instituições públicas de ensino superior a oferecerem cursos à distância.

Tais ofertas de ensino tiveram e seguem tendo respaldo em políticas públicas educacionais, em que evidenciamos, sobretudo, a portaria que atualizou e regulamentou o oferecimento de cursos de Educação a Distância (doravante EaD), em 2017. De acordo com Portal do Ministério da Educação (MEC), o objetivo dessa portaria é: "ampliar a oferta de cursos superiores na modalidade a distância, melhorar a qualidade da atuação regulatória do MEC na área, aperfeiçoando procedimentos, desburocratizando fluxos e reduzindo o tempo de análise e o estoque de processos" (MEC, 2019).

Além dessa portaria, outro marco institucional relevante foi a construção dos Referenciais de Qualidade para Educação Superior a Distância 
(2007), que foi realizado com a necessidade do surgimento de um documento oficial que guiasse o oferecimento de cursos EaD. Tal documento foi originado pelo Ministério da Educação e pela Secretaria de Educação a Distância (SEED).

Por outro lado, a literatura tem demonstrado que, para que exista um processo educacional à distância de qualidade, é imprescindível uma atuação do tutor coerente com as premissas que regem essa categoria. Sendo assim, muitos estudos no campo da Educação debatem o papel e a função dos tutores na EaD, os quais tecem sobre a relevância desses profissionais no ensino/aprendizagem virtual (MILL, CESÁRIO, 2018; SCHLÜNZEN, ALBUQUERQUE, 2014).

Nesse contexto, o objetivo deste trabalho é analisar de que maneira o documento oficial da Educação Referenciais de Qualidade para Educação Superior a Distância (2007) apresenta o papel do tutor online na EaD, uma vez que, como afirmamos anteriormente, trata-se de um documento oficial do MEC e da SEED.

Em vista do que expusemos anteriormente, apresentaremos, na próxima seção, o arcabouço teórico que fundamenta este trabalho. Posteriormente, abordaremos a metodologia de pesquisa, no que se refere à sua natureza e o procedimento de coleta e análise adotado. Por fim, discutiremos as análises do objeto de estudo, encaminhando-nos para as considerações finais do trabalho.

\section{FUNDAMENTAÇÃO TEÓRICA}

Esta seção será dedicada à apresentação dos estudos que fundamentam, teoricamente, nossas análises. Na primeira subseção (2.1), abordaremos, ainda que brevemente, sobre a Educação a Distância (EaD). Na subseção 2.2, trataremos a respeito da tutoria a distância.

\subsection{Educação a Distância (EaD)}

Como já mencionamos anteriormente, a Educação a Distância tem se manifestado já há alguns anos em processos educacionais públicos e privados. Muitos são os autores que discutem acerca do ensino/aprendizagem nessa modalidade, no que concerne tanto a sua teorização e problematização quanto suas implicações na prática, tais como Mill (2018), Schlünzen e Albuquerque (2014), Tori (2010), entre outros.

Primeiramente, é necessário ressaltar que concordamos com Tori (2010), o qual afirma que a Educação a Distância não deve ser contraposta, 
superficialmente, à convencional/presencial, já que o ensino presencial não implica, de modo consequente, que o aluno está presente e envolvido com 0 processo de ensino/aprendizagem. Além disso, no ensino virtual, o aprendiz pode estar muito interessado, permitindo, assim, que aprenda o conteúdo estudado. Desse modo, advogamos, como Tori (2010), que a EaD não deve ser desmerecida apenas porque é virtual, pois este não significa não ser efetivo.

Por outro lado, o avanço tecnológico ampliou as possibilidades de ensino. De acordo com o autor mencionado, "o desenvolvimento tecnológico a educação virtual e interativa (EVI) se tornou viável a baixo custo e sem barreiras geográficas ou sociais" (TORI, 2010, p. 31), que pode permitir maior acesso ao conhecimento e à oportunidade de obtenção de um título.

As considerações de Mill (2018, p. 199) coadunam com as ponderações realizadas anteriormente, pois o autor elucida que:

Particularmente nas últimas décadas, a EaD tem sido acolhida como modalidade de apoio a políticas públicas de formação de professores, gestores e cidadãos em geral. Isto é, a EaD tem sido considerada uma forma alternativa e complementar para potenciais pedagógicos e de democratização do conhecimento.

Nessa direção, os Referenciais de Qualidade para Educação Superior a Distância, objeto de nosso estudo neste trabalho, também trata desses princípios, uma vez que é o documento oficial que serve de diretriz para o oferecimento da EaD.

No que diz respeito às explicitações do documento sobre a EaD em si, é relevante salientar que o referencial preconiza que pensar a "Educação" deve ocorrer antes mesmo de se refletir a "distância". Em outras palavras, o documento explicita que o objetivo educacional deve ser o principal motivador da existência dessa modalidade, a fim de se alcançar a formação técnico-científica, para o trabalho, e política, na dimensão da cidadania, dos cursistas EaD. Assim, o documento compreendendo que a virtualidade não é uma entrave para alcançar uma Educação de qualidade.

Nesse sentido, o documento propõe que o ensino na modalidade a distância deve considerar três aspectos: (a) pedagógicos, (b) recursos humanos e (c) infraestrutura. Esses aspectos desdobram-se em oito tópicos que devem ser atendidos no Projeto Político Pedagógico dos cursos EaD, as quais organizamos no Quadro 1.

Quadro 1 - Tópicos que englobam a EaD de qualidade

1) Concepção de educação e currículo no processo de ensino e aprendizagem;

2) Sistemas de Comunicação;

3) Material didático;

4) Avaliação; 
5) Equipe multidisciplinar;

6) Infraestrutura de apoio;

7) Gestão Acadêmico-Administrativa;

8) Sustentabilidade financeira.

Fonte: Autoria Própria com base em Brasil (2007)

O Quadro 1 apresenta os tópicos que devem ser atendidos na construção do curso de formação superior EaD, com base no documento oficial.

Tendo em vista o que foi explicitado anteriormente, na próxima subseção abordaremos mais especificamente sobre a tutoria a distância, foco de nosso trabalho.

\title{
2.2. TUTORIA A DISTÂNCIA
}

A tutoria é uma classe profissional ainda muito discutida no âmbito educacional que envolve a EaD e as TDICs. Mill (2018) elucida que o termo ainda é muito controverso na literatura sobre o tema, nos estudos acadêmicos e mesmo na prática cotidiana de tutoria. De acordo com o estudioso:

No Brasil, as experiências de EaD, ao longo da sua história, adotaram tutor com concepções e sinonímia do tipo: educador on-line, mentor, orientador virtual, monitor pedagógico, eformador, formador virtual etc. Quando entendido como tutoria, há outras variações: tutor presencial, tutor virtual, tutor eletrônico, tutor a distância etc. Entretanto, apesar dessas variações nos nomes, todos são compreendidos no que geralmente conhecemos como tutores para EaD, profissionais responsáveis por acompanhar os estudos dos alunos em cursos a distância (MILL, 2018, p. 656).

Além disso, Albuquerque e Schlünzen (2014) afirmam que os tutores/formadores devem acompanhar os discentes, como agente da mediação educacional. Mill e Cesário (2018, p. 662-663) retomam historicamente a palavra tutor e explicitam que

\begin{abstract}
em Educação, as primeiras referências ao termo tutor surgem nas universidades do século XV, ligadas à figura do orientador religioso dos estudantes, que tinha por objetivo impor a fé e a conduta moral. É somente no século XX que o tutor assume o papel de orientador de trabalhos acadêmicos, significado incorporado aos atuais programas EaD (Sá 1988).
\end{abstract}

O documento Referenciais de Qualidade para Educação Superior a Distância também destaca o trabalho do tutor no ensino $\mathrm{EaD}$, que está incorporado no item "Equipe Multidisciplinar" (cf. Quadro 1). De acordo com o documento, os tutores podem ser considerados uma categoria profissional, 
importante para a Educação de qualidade. Estes participam ativamente do projeto pedagógico e devem estar sempre atualizados. Além disso, o referencial especifica o trabalho do tutor e do professor, diferenciando-os, ainda que ambos trabalhem em conjunto no processo de ensino/aprendizagem.

Os tutores a distância, segundo o documento, fazem a mediação entre os alunos e o apoio presencial. Dentre suas responsabilidades estão: a) esclarecer dúvidas; b) promover espaços de aprendizagem coletiva; c) oferecer material extra, complementar; d) participar dos processos avaliativos conjuntamente aos docentes. Assim, na próxima seção, apresentaremos a metodologia de pesquisa adotada neste trabalho.

\section{METODOLOGIA}

Este trabalho caracteriza-se como de paradigma qualitativo, uma vez que não verificamos hipóteses, mas observamos o que apresenta o escopo e os dados. Além disso, o estudo diferencia-se de uma pesquisa quantitativa, pois, além de não testarmos hipóteses, não utilizamos instrumentos objetivos com análises estatísticas (SELIGER, SHOHAMY, 1990). Consideramos que o trabalho também é descritivo-explicativo, na medida em que buscamos estabelecer descrições, explicações e relações entre o objeto de estudo e a fundamentação teórica (cf. seção 2).

No que se refere ao objeto de estudo, trata-se de um documento oficial da Educação, chamado Referenciais de Qualidade para Educação Superior a Distância (2007). Tal documento foi estabelecido pelo Ministério da Educação (MEC) e pela Secretária de Educação a Distância (SEED), com respaldo na regulamentação do ensino de EaD de 2007 (PORTAL MEC, 2017) atualizado em 2017. Como o próprio nome indica, esse documento foi realizado para servir de apoio e suporte nas práticas de ensino a distância. Nas palavras do documento: "ele será um referencial norteador para subsidiar atos legais do poder público no que se referem aos processos específicos de regulação, supervisão e avaliação da modalidade citada." (BRASIL, 2007, p. 2 - grifo nosso). Assim como outros documentos que respaldam políticas públicas, esse referencial foi construído por meio de um debate de uma equipe de pesquisadores e especialistas da área, com a sociedade e as universidades, visando oferecer um documento responsável e coerente.

Dando continuidade ao trabalho, elucidar, na próxima seção, as análises empreendidas.

\section{ANÁLISES}


Como já explicitamos nas seções anteriores, o documento Referenciais de Qualidade para Educação Superior a Distância foi proposto pelo MEC e SEED. Primeiramente, vale ressaltar que consideramos que esse referencial é um documento fundamental para ancorar institucional e nacionalmente a Educação a Distância no Brasil. Além disso, tal documento tinha força, naquele momento, em conjunto à regulamentação do ensino de EaD de 2007, o qual foi atualizado em 2017. No entanto, notamos que mesmo após a atualização da portaria sobre o oferecimento de cursos de ensino superior na modalidade EaD, em 2017, isto é, dez anos depois, não foi realizada nenhuma revisão do documento.

Consideramos que esse cenário é muito danoso para a Educação Superior, na medida em que após 10 anos de publicação do documento, pudemos vivenciar diversas mudanças sociais, culturais, etc., os quais conduziram para o avanço também das discussões sobre as Tecnologias na/com a Educação. Essa realidade é observável, por exemplo, com as transformações ocasionadas pela presença dos dispositivos móveis em nossas vidas, podendo até proporcionar o que os pesquisadores têm chamado de mobile learning (PALALAS, 2018). Tais mudanças na sociedade de informação e comunicação têm gerado amplos debates sobre os papéis no ensino/aprendizagem, uma vez que essas discussões são demandadas pela/na contemporaneidade. Desse modo, compreendemos que a existência do documento em questão é um marco institucional importante para a EaD e, nesse sentido, requereria de novas revisões e atualizações para nosso contexto hodierno.

No que concerne ao nosso objetivo, analisar de que maneira o documento oficial Referenciais de Qualidade para Educação Superior a Distância (2007) apresenta o papel do tutor online na EaD, há um item do documento destinado à "Equipe Multidisciplinar", que compreende os tutores. Os tutores a distância, segundo o documento, fazem a mediação entre os alunos e o apoio presencial. São suas responsabilidades: (1) esclarecer dúvidas; (2) promover espaços de aprendizagem coletiva; (3) oferecer material extra, complementar; (4) participar dos processos avaliativos conjuntamente aos docentes.

Nesse sentido, está claro que a função do tutor é de guiar, contribuir, orientar e motivar os estudantes, na busca e construção do conhecimento. Esse posicionamento está de acordo com a fundamentação teórica (apresentada na seção 2), tendo em vista que, de acordo com Albuquerque e Schlünzen (2014), os tutores a distância são agentes do processo educacional, mediando os aprendizes e o conteúdo.

Contudo, salientamos que para que essa prática ocorra, é imprescindível que o tutor tenha conhecimento do conteúdo que está mediando 
e que possua conhecimento técnico digital-tecnológico. Tal preocupação também está expressa no documento oficial, integrando as responsabilidades requeridas para o exercício da tutoria a distância.

Por outro lado, destacamos, assim como Mill e Cesário (2018), as questões trabalhistas da categoria profissional tutor. Os tutores não possuem vínculo empregatício e possuem contratos temporários. Eles são, frequentemente, mal remunerados ou recebem bolsas de pesquisa e, ainda, recebem uma quantidade de trabalho elevada.

A Educação a Distância sofre nesse cenário, haja vista que esses obstáculos impedem que se alcance os princípios elencados tanto pelas teorias sobre $\mathrm{EaD}$ quanto pelo documento oficial tratado. Concordamos com Mill e Cesário (2018, p. 664), os quais afirmam que:

\begin{abstract}
Por essas e outras questões (trabalhistas, pedagógicas, técnicas, administrativas e de formação), a tutoria virtual é uma questão em aberto, um processo ainda em construção, uma função em definição e caracterização. Essas questões precisam ser mais bem definidas, pois a EaD está em expansão e sua qualidade depende, sobremaneira, da função do tutor virtual.
\end{abstract}

Dessa maneira, consideramos que as dificuldades postas na realidade prática dificultam o cumprimento do exposto pelo documento oficial sobre a tutoria a distância. Além disso, tais questões, como por exemplo a falta de regulamentação profissional, não estão presentes nesse referencial, talvez porque sua realização foi em 2007, quando essa prática de ensino ainda não era tão popularizada e comum como é nos dias atuais.

Nessa direção, as políticas públicas poderiam contribuir para a atualização do documento oficial Referenciais de Qualidade para Educação Superior a Distância, de 2007, pois, assim, também dariam suporte a essa categoria importante, mas ainda tão desvalorizada. Nessa direção, também contribuiriam para a construção da EaD no Brasil, para que seja séria, comprometida e responsável.

\title{
5. CONSIDERAÇÕES FINAIS
}

Os processos de Educação a Distância ainda são amplamente debatidos na Sociedade, nas Universidades e nas Políticas Públicas. Desse modo, este trabalho objetivou analisar de que maneira o documento oficial Referenciais de Qualidade para Educação Superior a Distância, de 2007, apresenta o papel do tutor on-line na EaD. 
Refletimos sobre o papel desse documento na $\mathrm{EaD}$ no ensino superior, sua relevância, sobretudo no que diz respeito à tutoria a distância ou virtual. Concluímos que o documento está em consonância com os estudos sobre o EaD, no que concerne a relevância do tutor nos processos de ensino/aprendizagem (MILL, CESÁRIO, 2018; ALBUQUERQUE E SCHLÜNZEN; 2014).

No entanto, abordamos sobre a importância do conhecimento teórico e digital-tecnológico dessa categoria. Além disso, enfatizamos a condição de trabalho dos tutores na $\mathrm{EaD}$, que pode impedir de que as funções, que mantém a qualidade do ensino, ocorram.

Apontamos para a ausência da atualização dos Referenciais de Qualidade para Educação Superior a Distância pelo MEC, que pode implicar na negligência da EaD no Brasil. Por outro lado, demonstramos a importância de um documento como parte do processo de valorização dessa categoria na Educação.

Por fim, compreendemos a limitação deste trabalho, uma vez que buscamos analisar apenas um aspecto que constitui a $\mathrm{EaD}$ no documento oficial e há outras questões que poderiam ser abordadas, entretanto, esse foi o escopo deste trabalho. Consideramos que trouxemos contribuições para o campo da Educação, em especial, as relacionadas com as TDICs e a EaD, bem como o papel da tutoria, suas funções e responsabilidades. Além disso, esperamos ter incitado indagações para o surgimento de trabalhos futuros.

\section{REFERÊNCIAS}

ALBUQUERQUE, D. I. P.; SCHLÜNZEN, E. T. M. O processo de formação permanente em serviço e em exercício de formadores para a docência virtual, Tese de Doutorado, FCT/Unesp, 2014.

BRASIL. Referenciais de Qualidade para Educação Superior a Distância. $2007 . \quad$ Disponível em: $<$ http://portal.mec.gov.br/seed/arquivos/pdf/legislacao/refead1.pdf $>$. Acesso em 04 de junho de 2019.

MILL, D.; CESÁRIO, P. M. Tutoria virtual. In: MILL, D. (Org.) Dicionário Crítico de Educação e Tecnologias e de Educação a distância. Campinas: Papirus, 2018, p. 662-665.

Tutoria na educação a distância. In: MILL, D. (Org.) Dicionário Crítico de Educação e Tecnologias e de Educação a distância. Campinas: Papirus, 2018, p. 656-659. 
PALALAS, A. Mindfulness in Mobile and Ubiquitous Learning: Harnessing the Power of Attention. In: SHENGQUAN, Y.; MOHAMED, A. AVGOUSTOS, T. (Org.) Mobile and Ubiquitous Learning: An Internacional Handbook. Singapura: Springer, 2018, p. 19-44.

SELIGER, H.W. \& SHOHAMY, E. Second Language Research Methods. Oxford: OUP, 1990.

TORI, R. Educação sem distância: as tecnologias interativas na redução da distâncias em ensino e aprendizagem. São Paulo: Editora São Paulo, 2010. P. 25-35. 


\title{
A VISÃO DO ESTUDANTE DE MEDICINA SOBRE AS TUTORIAS E O PAPEL DO PROFESSOR-TUTOR EM ABP (APRENDIZADO BASEADO EM PROBLEMAS), À LUZ DA ANÁLISE DISCURSIVA
}

\author{
BANDOS, Rogério Dutra \\ Médico, Docente, Mestre em Otorrinolaringologia (USP) \\ Membro do GEPALLE (Grupo de Estudos e Pesquisas sobre Alfabetização, \\ Leitura e Letramento da USP - Ribeirão Preto) \\ othosdrrogerio@gmail.com
}

ASSOLINI, Filomena Elaine Paiva Graduada em Pedagogia e Letras, Mestre e Doutora em Psicologia (USP) Pós-doutora em Linguística (Unicamp) Docente e Líder do GEPALLE elainefdoc@ffclrp.usp.br

\section{INTRODUÇÃO}

O ensino médico no Brasil sofreu mudanças significativas nas últimas décadas. Experiências apoiadas por organizações internacionais, foram desencadeadas principalmente em programas de medicina e enfermagem, em algumas instituições brasileiras, a partir da década de 1990 (FEUERWERKER, 1998). Um dos marcos desta mudança foi a implementação das Diretrizes Curriculares Nacionais do Curso de Graduação em Medicina, pelo Ministério da Educação, no ano 2001 (BRASIL, 2001). Nestas diretrizes, a nova grade curricular proposta propunha aspectos que buscavam na formação dos egressos de escolas médicas brasileiras o perfil generalista, humanista, crítico, reflexivo e pautado em princípios éticos. Ao estudante caberia adquirir competências cognitivas (conhecimento), habilidades específicas e afetivas, bem como estar preparado para exercer a atenção à saúde em ações de prevenção, promoção, proteção e reabilitação, em nível individual, coletivo e integrado ao Sistema Único de Saúde (SUS).

Estas diretrizes sofreram poucas alterações, por meio de alguns pareceres, até o ano 2014, quando foi revogada e substituída por novas diretrizes (BRASIL, 2014), que, no entanto, mantiveram em geral o perfil almejado dos médicos egressos, como o caráter reflexivo e mantenedor da própria educação permanente. Destaca-se, nestas novas diretrizes, as orientações aos cursos sobre as práticas educacionais indicadas para esta formação, como enuncia um de seus artigos: 


\begin{abstract}
avaliação do processo ensino-aprendizagem e do próprio curso, bem como desenvolver instrumentos que verifiquem a estrutura, os processos e os resultados, em consonância com o Sistema Nacional de Avaliação da Educação Superior (SINAES) e com a dinâmica curricular definidos pela IES (Instituição de Ensino Superior) em que for implantado e desenvolvido.
\end{abstract}

Neste contexto, o presente estudo tem 0 objetivo de saber $e$ examinar o que pensam estudantes de medicina de uma instituição de ensino do interior do estado de São Paulo sobre alguns aspectos das atividades educacionais praticadas na instituição, notadamente nas atividades tutoriais. Para sua realização, foi utilizado um questionário com nove perguntas discursivas sobre temas relacionados ao ABP (Aprendizado Baseado em problemas), ou PBL (Problem Based Learning), relacionados sobretudo aos papéis e atribuições do tutor e dos estudantes nas atividades tutoriais.

Como procedimentos metodológicos, este estudo foi realizado a partir de uma pesquisa exploratória, inicialmente baseada em dados secundários que compuserem a revisão bibliográfica, e posteriormente, em dados primários obtidos por meio de um questionário respondido por onze estudantes do terceiro ano de medicina de uma faculdade do interior do estado de São Paulo. As respostas foram submetidas à Análise de Discurso de Matriz Francesa $(A D)$.

O presente artigo encontra-se dividido em sequência a esta introdução por uma breve revisão da literatura, que aborda os temas: mudanças recentes no ensino médico no Brasil; $A B P(P B L)$ e $A D$, seguidas da metodologia utilizada, dos resultados e discussões, das conclusões e das referências.

\title{
3. REVISÃO DA LITERATURA
}

Historicamente, o processo de ensino médico, em seu aspecto teórico, foi feito com base em um currículo tradicional, ou seja, baseado em aulas expositivas convencionais em sua maior parte (FEUERWERKER, 1998), onde o professor, centro das atenções, expõe seu conteúdo a um grupo ou plateia mais passiva. Nas metodologias ativas, como as citadas no Art.32 das diretrizes de 2014, estudante, e não o professor, é colocado no centro do processo ensino-aprendizagem, devendo assumir o protagonismo deste processo. 
Dentro das metodologias ativas, um modelo de ensino surgiu no Canadá em 1969, na Universidade McMaster: o Problem-Based-Learning (PBL), ou Aprendizado Baseado em Problemas (ABP). Neste método, que anos após foi adotado pela Universidade de Maastrich, na Holanda, a grade curricular teórica, no lugar de aulas expositivas convencionais, é fortemente baseada no estudo de casos ou situações-problemas, verossímeis, reais ou baseados em casos reais, previamente escritos, com a função de provocar discussões, investigações, resoluções e conclusões entre os estudantes, gerando assim o aprendizado (LU et al., 2015).

Estas discussões muitas vezes são feitas em grupos menores, com cerca 8-12 alunos, sob a coordenação e supervisão de um professor-tutor, geralmente (não obrigatoriamente) um médico. Nesta etapa de discussão inicial, há a leitura e exploração dos dados do caso-problema, muitas vezes como uma brain-storm, formulando hipóteses diagnósticas e objetivos de aprendizagem. Após esta etapa, que usualmente é chamada de abertura do problema, é dado ao estudante um tempo (normalmente poucos dias) para que ele, baseado nestes objetivos, pesquise e estude a matéria proposta (por exemplo, uma ou mais patologias).

No encontro seguinte, já com maior conhecimento dos assuntos, o estudante deverá ser capaz de expor e discutir o conhecimento adquirido aos pares e ao tutor, cumprindo os objetivos propostos na abertura, além de esclarecer dúvidas, ou seja, "resolver" o caso. Esta etapa, normalmente chamada de fechamento do problema, encerra um ciclo naquele assunto, que junto a outros assuntos formam módulos de ensino em determinado tema ou sistema (como por exemplo, patologias do sistema digestivo ou transtornos mentais) (WOOD, 2003).

O ABP abarca e permite vários modelos que diferem entre si, praticados nas diferentes universidades no Brasil e no mundo, principalmente no que se refere à organização dos assuntos abordados nos problemas, composição e duração dos módulos, tempo de discussão, dinâmica da tutoria, funções específicas de um estudante na tutoria (como coordenador da discussão ou relator da matéria), metodologia de avaliação do estudante (formativa/ somativa), além do papel do professor-tutor como direcionador, facilitador, detentor do conhecimento e avaliador do processo ensinoaprendizagem.

Um modelo referencial ou padrão muito utilizado na dinâmica de uma tutoria é o modelo dos sete passos, descritos a seguir, que se sucedem entre a abertura e o fechamento de um caso-problema (WALSH, 2005): 


\begin{abstract}
Abertura do problema
1- Identificação do problema (leitura inicial do caso)

2- Exploração de conhecimento prévio

3- Geração de hipóteses e de possíveis mecanismos envolvidos

4- Identificação das questões (objetivos) de aprendizagem
\end{abstract}

\author{
Fechamento do problema \\ 5- Estudo próprio (fora da sessão tutorial) \\ 6- Nova discussão e aplicação do novo conhecimento ao problema \\ 7- Avaliação e reflexão do aprendizado
}

O modelo adotado pela universidade do presente estudo assemelha-se ao descrito acima, sendo as avaliações processuais (ou formativas) realizadas durante as sessões tutoriais, de acordo com 0 desempenho do estudante nos descritores de avaliação, que abordam tanto seus aspectos cognitivos como comportamentais.

Neste processo, o feedback, tanto do professor-tutor para o estudante, bem como do estudante para o docente e à instituição, é ferramenta importante de diagnóstico e norteamento de ações e ajustes no processo educacional, sendo o modelo do presente estudo, coletando e analisando respostas dos estudantes sobre o curso, uma destas possíveis ferramentas (GOMES, et al., 2010).

Para esta análise, foi escolhida a Análise de Discurso (AD) de Matriz Francesa, disciplina ou metodologia de interpretação e exame crítico de textos, escritos ou orais, que identifica, explora e valoriza aspectos textuais e contextuais para além da Linguística (BRANDÃO, 1995).

Surgida e estruturada por Michel Pêcheux (1938-1983) e outros como Jacques Courtine, Dominique Maingueneau, a partir do final da década de 1960, a AD situa sua reflexão sobre a relação entre a Linguística e a Teoria do Discurso. A Linguística, que tem o mestre genebrês Saussure como pioneiro, é o campo a partir do qual a $A D$ está inserida e dela tenha se desenvolvido (FIORIN, et al., 2013). No entanto, para a AD, o sistema linguístico, ou seja, o interno, não é suficiente: a língua deve ser estudada também em seu exterior, inserida em um contexto histórico (BONÁCIO, 2017). 
Reforçando esta noção, Orlandi (1998) chama a atenção para o fato de que a tarefa de quem analisa o discurso é compreender a relação entre o real da língua e o real da história. Desse ponto de vista, a produção de sentidos deve ser vista como uma relação entre o sujeito e a história.

Nesta relação, o sujeito discursivo é afetado por fatores que determinam ou possibilitam o discurso, como seu contexto histórico e sua concepção de mundo, ou seja, sua ideologia. Assim, o discurso é constituído por diferentes vozes sociais (sujeito polifônico), e marcado por grande heterogeneidade e conflitos, em que o desejo se inter-relaciona com o social e manifesta-se por meio da linguagem, entendida na $A D$ em seu caráter flexível e não permanente (FERNANDES, 2008).

Três regiões do conhecimento articulam-se com a AD: 0 materialismo histórico, com base na releitura que Althusser faz dos textos de Marx; a Linguística, como teoria dos mecanismos sintáticos dos processos de enunciação; a Teoria do Discurso, como teoria da determinação histórica dos processos semióticos. Essas teorias são atravessadas por uma teoria psicanalítica da subjetividade, ou mais especificamente, pela releitura que Lacan faz dos estudos de Freud. Pêcheux chama "a tripla entente": Saussure, Marx e Freud, como fundamento toda sua obra. Apesar desse caráter interdisciplinar, ao buscar complementação na história e na psicanálise, a $A D$ pertence ao campo da linguística (PAULON, et al., 2014; BRANDÃO, 1995).

Além da AD de Matriz Francesa, outras análises de discurso se destacam: a eslava, tributária dos Círculos de Bakhtin, e a anglo-saxônica, de Fairclough, van Djik etc., que se intitula Análise Crítica do Discurso, de caráter intervencionista e baseada na ideia de aufklarung (esclarecimento) (SOARES, 2015).

Um estudo semelhante ao presente utilizou-se da AD para avaliar a perspectiva de estudantes de medicina, obtendo resultados que foram considerados confiáveis e importantes como instrumento de $A B P$ em uma escola médica nova e também com currículo baseado em PBL (RONDON, et al., 2018).

\section{METODOLOGIA}

O presente artigo é uma pesquisa exploratória qualitativa, com seus resultados submetidos à $A D$ de Matriz Francesa. As perguntas foram elaboradas a partir da experiência e vivência em educação pelos autores, com 
o objetivo de examinar o que pensam estudantes de medicina da uma instituição de ensino do interior do estado de São Paulo que adota, desde seu início, o PBL como base curricular, sobre importantes aspectos das atividades educacionais praticadas na instituição, com enfoque nas sessões tutoriais ou tutorias.

Desta forma, foi feita uma breve revisão bibliográfica sobre os temas: ensino médico contemporâneo no Brasil, PBL e tutorias e $A D$, para então tratar-se da pesquisa em si.

Foi selecionada uma amostra de conveniência, constituída de estudantes de dois grupos de tutoria, e a estes, foi aplicado um questionário com nove perguntas discursivas (em apêndice), relativas às tutorias, para um grupo de estudantes de um mesmo grupo tutorial. Optou-se por pedir por mais dois membros aleatórios, de outro grupo, para participarem do estudo, para garantir um número mínimo desejado de dez participantes.

O questionário foi enviado via e-mail nos primeiras semanas do mês de julho de 2019, no início das férias. No e-mail enviado, previamente foi esclarecido que a participação do estudante era espontânea e não obrigatória, que seus nomes não seriam publicados ou conhecidos a não ser pelos pesquisadores, e sem implicar qualquer tipo de prejuízo ao estudante.

Dos 12 estudantes, 11 responderam ao questionário, e foram chamados de acordo com um número cada um (estudante 1;2...11) no presente estudo. Como a turma toda do terceiro ano na data do presente estudo é composta de 62 estudantes, a amostra representa cerca de $18 \%$ da turma.

O sujeitos estudantes do presente estudo são universitários de idade que tem de 20 a 30 anos de idade (média 24 anos), sendo oito do sexo feminino e três do sexo masculino. Todos tem ao menos dois anos e meio de experiência em PBL e tutorias, que terminam no final do quarto ano letivo, quando se encerra esse ciclo (que é básico mas desde o princípio com vivências práticas, como é usualmente característica do currículo em ABP), e se iniciam as atividades de internato (mais dois anos, totalizando os seis anos da graduação médica).

Das nove perguntas feitas aos estudantes, foi feito um recorte temático de acordo com o interesse da presente pesquisa, sendo que seis delas foram utilizadas (perguntas 1-2 e 6-9). As três outras (3-5) dizem respeito ao papel do estudante de relator e coordenador do problema, e da maneira de determinação dos objetivos de aprendizagem, deverão ser objeto de pesquisa em outro estudo.

As perguntas 1 e 2, utilizadas no questionário do presente artigo dizem respeito ao estudo prévio para as aberturas, que era prática comum 
entre os estudantes, sobretudo antes das mudanças adotadas no início de 2019, com a alteração dos descritores de avaliação, feitas por uma comissão interna da universidade, estabelecida no ano anterior (2018) para repensar o currículo. Uma das mudanças estabelecidas por esta comissão se refere ao item "Utiliza conhecimentos prévios?", que era um dos três descritores utilizados como critério de avaliação das aberturas das tutorias desde o início na universidade, Este item foi abolido no início do semestre de 2019 alteração que foi devidamente comunicada e discutida com os demais tutores na ocasião - , a partir de percepções de alguns tutores e de alunos, de que o item poderia vir a prejudicar a geração de hipóteses na abertura, além de ser fator gerador de ansiedade e competição entre os alunos, o que mostrou-se, como descrito adiante no presente estudo, em consonância com as respostas dos estudantes.

As perguntas 6 a 9 foram elaboradas para conhecer os sentimentos e as opiniões dos estudantes para com as tutorias, notadamente a adequação e adaptação ao modelo tutorial praticado, critérios de avaliação, percepção da ansiedade, papel e desempenho do tutor, em busca de um modelo que thes pareça ideal.

Após a fase de coleta de dados, as respostas foram submetidas à $A D$ de matriz francesa, que permitiu abranger diversos aspectos importantes (con)textuais, além da estrutura discursiva.

\section{RESULTADOS E DISCUSSÃO}

As respostas obtidas no presente estudo para as perguntas 1 e 2 estão inter-relacionadas, por tratarem do mesmo assunto: o estudo prévio da matéria antes das aberturas dos problemas. Na primeira pergunta, busca-se conhecer, de modo geral, a opinião do discente sobre esta modalidade de estudo nas tutorias, em seus aspectos como validade e viabilidade. A segunda pergunta aborda a percepção dos estudantes frente às medidas adotadas na instituição no início daquele semestre (cerca de cinco meses antes), que aboliu o item "Utiliza conhecimentos prévios?", um dos três itens de avaliação processual (ou formativa) na abertura.

É importante ressaltar que a avaliação processual, sobretudo no currículo do ABP e especificamente nas tutorias (incluídas na universidade em questão), usualmente tem peso importante na nota final, que é computada às avaliações somativas. O presente estudo confirmou que as notas das avaliações processuais tem o potencial de fazer surgir ou aumentar a 
ansiedade no estudante, pela preocupação com sua nota final para progressão no curso.

Esta ansiedade gera uma inquietação nos estudantes, e sua relação com o estudo prévio para aberturas, pode ser demonstrada na resposta do estudante 1 para a primeira pergunta:

\begin{abstract}
Acho que o estudo prévio só seria benéfico se fosse algo estipulado tanto pelos alunos tanto com o tutor, assim como o tema a ser estudado e a bibliografia...Porém, o estudo prévio como ocorre em alguns casos atualmente, na maioria das vezes é uma atitude que prejudica tanto o grupo como o próprio aluno. Pois, além de não permitir uma discussão livre e cheia de hipóteses durante a abertura, muitas vezes é usada como forma de tentar aumentar a própria nota. Isso aumenta a competitividade, aumenta o nível de ansiedade préabertura e prejudica a relação interpessoal do grupo (estudante 1).
\end{abstract}

O estudante 1 revela ainda preocupação com a aplicação plena das mudanças adotadas, pois, segundo ele, em alguns casos o estudo prévio, bem como sua valorização na tutoria, pode ainda persistir, talvez por tratar-se alterações relativamente recentes, ainda não totalmente assimiladas.

No entanto, as percepções das mudanças pelos sujeitos estudantes analisados mostram certo alívio na ansiedade e preocupação excessiva antes das aberturas das tutorias, em uma grade curricular já densa, indicando claramente os benefícios desta mudança para eles, de uma forma geral, como observado em uma resposta à pergunta 2: "Foram muito positivas. Isso não é uma opinião individual, pois, conversando com colegas de turma, percebemos que isso deixou a tutoria fluir cada vez mais"...(estudante 3 ).

O presente estudo mostrou-se em consonância com o que já se havia detectado no estudante através de conversas com alunos e em portfólios reflexivos feitos pelos estudantes anteriormente: que a valorização avaliativa do conhecimento prévio, que era em sua grande maioria adquirido às vésperas da abertura e não formalmente recomendado ou orientado pela instituição, era fator gerador de ansiedade e competição.

O estudante 11 também mostrou-se incomodado com o estudo prévio nas tutorias, ao ressaltar que conhecimento anteriormente demonstrado nas aberturas não representava o conhecimento real e solidificado da matéria, ao escrever:

Na minha opinião o estudo prévio antes das aberturas de tutoria não é válido, pois quando esse é realizado faz-se de uma maneira superficial e visando apenas decorar partes do conteúdo e não entendê-las (estudante 11).

As análises das respostas dos sujeitos estudantes, percebidos nas análises indiciárias, foram unânimes em revelar como sendo positivas e 
importantes as mudanças feitas pela comissão sobre o estudo prévio, que era visto como fator de preocupação e aborrecimento.

As respostas dos 11 sujeitos estudantes submetidas à AD sobre a tutoria e o papel do tutor, reveladas nas perguntas 6-9, mostraram enfoques idiossincráticos e pontos em comum entre os sujeitos-estudantes.

Mais uma vez, a ansiedade é abordada na pergunta 6, que tratada dela nas tutorias, e sua relação com outros fatores como atuação do tutor, avaliação, em relação a outras áreas do curso. Detecta-se, nas respostas dos sujeitos estudantes, a noção do potencial que tem as tutorias em tornar-se fator de estresse e ansiedade (mesmo por antecipação), além de alguns sujeitos estudantes salientarem prejuízos na qualidade de vida e do aprendizado, como relatado pelo estudantes 5: "A tutoria sempre foi o que mais trouxe ansiedade para nós estudantes"...(estudante 5). Outro estudante complementa esta noção, ao afirmar: "Estresse em excesso compromete a consolidação do conhecimento e a qualidade de vida do aluno"(estudante 9).

Sobre a figura do tutor, o questionário reservou as três últimas perguntas. A de número 7 questiona qual a importância de um tutor com bom domínio do assunto abordado (ainda que não seja especialista naquela área), haja visto que nas metodologias ativas como o $A B L$, o protagonismo (ou grande responsabilidade) do aprendizado é, em linhas gerais, muito atribuída ao estudante.

As respostas revelam a importância que os estudantes dão ao tutor e às suas ações, pois tem nele alguém mais experiente, e que deve estar atento para a condução e verificação de uma tutoria que aborde adequadamente os temas discutidos. Nas palavras de um estudante: "É fundamental que o tutor seja o mais preparado possível, pois ele deve conduzir os alunos a discutir sobre o tema" (estudante 4). Outro escreveu: "É importante que os tutores tenham um bom domínio sobre o conteúdo para evitar equívocos e erros em conceitos cometidos pelos alunos nas tutorias" (estudante 11).

As duas últimas perguntas do questionário, também relacionadas ao tutor, perscrutam sobre a sua atuação e seus atributos. A número 8 indaga sobre sua atuação como norteador da tutoria, além dos métodos e critérios de avaliação, enquanto a número 9 pergunta de modo geral quais são, para eles, as características do tutor ideal.

No questionamento sobre um modelo ideal de tutoria, foram sugeridas por três estudantes (5, 7 e 10), a inclusão avaliações somativas dentro das tutorias, ou seja, que sejam adotadas questões (valendo notas) nos fechamentos. Para a estudante 5, a abertura não deveria mesmo ser avaliada 
no final, e as questões no fechamento agregariam conhecimento aos estudantes.

$\mathrm{Na}$ análise discursiva destes itens, percebe-se que os sujeitos estudantes almejam encontrar em seu tutor alguém que os auxilie, facilite e direcione no processo ensino-aprendizagem. De modo geral, que a análise das respostas mostram que este tutor deve ser participativo na medida certa, e não seja tão passivo, mas saber orientar quando oportuno, além de zelar pela unidade entre os estudantes, sem deixar de colaborar com aspectos relacionados à sua experiência profissional.

Quatro trechos destacados do questionário mostram aspectos relevantes sobre o que pensam os estudantes sobre a atuação (ideal) dos tutores. Analisando as respostas, mais uma vez percebe-se a importância de uma boa atuação do tutor para os sujeitos estudantes, tanto para a harmonia no grupo quanto para o bom proveito do processo ensino-aprendizagem: "Acredito que nas aberturas, os tutores poderiam participar mais, direcionar a discussão...e instigando-os no fechamento" (estudante 8). Outros escreveram sobre aspectos desejáveis ao tutor: "Acho que o equilíbrio é essencial ao tutor. Não ser super rígido...ser justo na medida do possível” (estudante 6). Ainda:

\begin{abstract}
...que não estimule a competição entre os alunos...que tem a capacidade de fazer o grupo todo interagir e construir o conhecimento em conjunto, que interfira quando necessário, passando conhecimento ou de outra forma (estudante 9).
\end{abstract}

Não faz "terrorismo" com nota, identifica fragilidades e aponta a direção quando necessário, participa quando necessário (seja na abertura ou fechamento), avalia segundo descritores, ajuda o aluno melhorar pontos fracos e destaca os fortes (estudante 2).

De modo geral, pode-se dizer que praticamente todas respostas analisadas no presente estudo foram bem elaboradas, e não demasiadas curtas, como feitas por quem respondesse o questionário apenas por responder, o que mostra o engajamento, ou o compromisso do discente para com seu processo ensino-aprendizagem.

Ainda que as universidades modernas, em geral, mostrem-se abertas ao diálogo e aos ajustes quando necessários, essa percepção pode ser diferente para cada estudante. Assim, acreditamos que eles viram na pesquisa uma oportunidade para se expressarem, em busca de terem seus pontos de vista considerados e mesmo eventualmente atendidos, pois sabiam que tratava-se de uma pesquisa com fins de publicação, mas também, ferramenta de feedback.

Nota-se, neste contexto, uma possível prática discursiva como um universo de concorrências, onde diferentes vários emissores "competem" entre 
si (ainda que possam também somar forças), com o intuito de mostrar e convencer determinado(s) receptore(s) sobre seus pontos de vista, como na relação descrita por Foucault entre o discurso, o desejo (do sujeito que discursa) e o poder almejado por ele (FOUCAULT, 1971).

Pode-se perguntar sobre a real validade das opiniões dos estudantes de medicina neste processo, e, para isso, encontramos na literatura que, embora possam ser ingênuos para saber o que é melhor para eles e "ignorar o que ignoram", planejadores curriculares devem considerar seriamente os pontos de vista dos estudantes de medicina, que tem um grande senso de utilidade e são rápidos em se opor passivelmente a atividades que acham pouco importantes, e são geralmente capazes de reconhecer as atividades que geram ganhos reais de aprendizagem (SRINIVASAN, et al., 2007).

Assim, para saber o que os discentes pensam, instrumentos de coleta de informações através de portfólios reflexivos, encontros, reuniões, além de pesquisas de opinião como esta, são válidas, sobretudo quando devidamente registradas, analisadas e valorizadas (GOMES, et al., 2010). Deste modo, podem mostrar-se importantes ferramentas de feedback e ajuste do processo ensino-aprendizagem, úteis na manutenção e ampliação da qualidade dos cursos médicos modernos, onde os aspectos técnicos e humanísticos são indistintamente importantes.

\section{CONCLUSÃO}

O presente estudo permite concluir que:

$\left.1^{\circ}\right) \mathrm{Na}$ posição de sujeito estudante, há preocupação e desconforto dos entrevistados em relação ao estudo prévio das matérias. A análise indiciária dos resultados destaca a inquietação dos estudantes no que diz respeito à competição e ao suposto domínio do conteúdo advindo mais da memorização e menos da compreensão dos conteúdos;

$2^{\circ}$ ) A mudança metodológica que retirou o estudo prévio dos itens de avaliação foi entendida como positiva;

$3^{\circ}$ ) A tutoria ideal, segundo os entrevistados, envolve 0 direcionamento nas aberturas, síntese e retomadas nos fechamentos dos estudos.

Por fim, e de modo mais amplo, o estudo mostrou-se uma ferramenta viável em sua execução e no cumprimento de seus objetivos, 
podendo ser replicada e ampliada nestes ou em semelhantes formatos, em busca do aperfeiçoamento educacional praticado nos cursos de medicina (ou outros que se utilizam do ABP), como preconizam as Diretrizes Curriculares Nacionais do Curso de Graduação em Medicina de 2014.

\section{REFERÊNCIAS}

ALLYN, W. -The tutor in PBL - Problem Based Learning - a novice's guide Mac Master University. http://fhs.macmaster.ca/facdev/documents /tutor PBL .pdf. Acesso em 22 jul. 2019.

BONÁCIO, D. A teoria do discurso no cenário linguístico: uma nova via para o embate interior $x$ exterior nos estudos da linguagem. Acta Scientiarum. Language and Culture, vol. 39, núm. 4, 2017, Disponível em $<$ http://www.redalyc.org/iatsRepo/3074/307455321014/html/index.html>. Acesso em 22 jul. 2019.

BRANDÃO, H. H. N. Introdução à Análise do Discurso. 2a edição. Campinas (SP): Editora da UNICAMP, 1995.

BRASIL. Ministério da Educação. Resolução CNE/CES N³, de 20 de junho de 2014. Institui Diretrizes Curriculares Nacionais do Curso de Graduação em Medicina e dá outras providencias. Disponível em http://portal.mec.gov.br/ index.php? option=com docman\&view=download\&alias $=15874-\quad$ rces003-14\& category slug =junho-2014-pdf\&ltemid=30192. Acesso em: 20 jul. 2019

BRASIL. Ministério da Educação. Resolução CNE/CES № 4, de 7 de novembro de 2001. Institui Diretrizes Curriculares Nacionais do Curso de Graduação em Medicina. Disponível em http://portal.mec.gov.br/cne/arquivos/pdf/CES04.pdf. Acesso em 20 jul. 2019.

FERNANDES, C.A.; Análise do discurso - reflexões introdutórias. Editora Claraluz. 2008. Disponível em <https://pt.scribd.com/document/330814664/ CLEUDEMAR-FERNANDES-Analise-Do-Discurso-Reflexoes-Introdutorias.> Acesso em 22 jul. 2019.

FEUERWERKER, L. C. M. Changes in medical education and medical residency in Brazil. Interface - Comunicação, Saúde, Educação, v. 2, n. 3, 1998.

Disponível

em 
$<$ https://www.researchgate.net/publication/34252447 Mudancas na educacao medica e resistencia medica no Brasil> Acesso em 27 jul. 2019.

FIORIN, J. L.; FLORES, V. do N.; BARBISAN, L.B. Por que ainda ler Saussure?. In (org.). Saussure e a invenção da linguística. São Paulo: Editora Contexto, 2013, p.07-20. Disponível em file://C:/Users/Usuário/Downloads/saussure a invenc o da linguistica apresentac o.pdf. Acesso em 3 ago. 2019.

FOUCAULT, M. (1971). A ordem do discurso. 3a Edição. Disponível em https:// moodle.ufsc.br/pluginfile.php/1867820/mod resource/content/1/ $\quad$ FOUCAULT\% 2C\%20Michel\%20-\%20A\%20ordem\%20do\%20discurso.pdf. Acesso em 28/7/2019.

GOMES, A. P. et al. Avaliação no Ensino Médico: o papel do portfólio nos currículos baseados em metodologias ativas. Rev. bras. educ. med., Rio de Janeiro, v. 34, n. 3, p. 390-396, Sept. 2010 .Disponível em <http://www.scielo.br/pdf/rbem/v34n3/08.pdf. $>$ Acesso em 20 ago. 2019.

LU, J; BRIDGES, S.; HMELO-SILVER, C. Problem-Based Learning. - Capítulo 15. In: SAWYER, R.K. The Cambridge Handbook of the Learning Sciences.Cambridge University Press, 2014.

ORLANDI. E. P. O próprio da análise do discurso (Escritos). Campinas, SP: Labeurb/Unicamp, 1998.

PAULON, A.; NASCIMENTO, J. V.; LARUCCIA, M.M. Análise do Discurso: Fundamentos Teórico-Metodológicos. Revista Diálogos Interdisciplinares 2014, vol.3, $\quad \mathrm{n}^{\circ}$.1.Disponível em <https://www.researchgate.net/publication /261698697_ > Acesso em 28 jul. 2019.

RONDON et al. A Implantação da Aprendizagem Baseada em Problemas PBL, no Curso de Graduação em Medicina da Universidade do Estado do Mato Grosso Sob a Perspectiva dos Estudantes. 2018. Disponível em < https://www.researchgate.net/publication/326794647 A Implantacao da Aprendizage m Baseada em Problemas - PBL no Curso de Graduacao em Medicina da Universidade do Estado do Mato Grosso Sob a Perspectiva dos E studantes/link/5b63e41b0f7e9b00b2a25313/download> Acesso em 23 jul 2019.

SRINIVASAN, M, et al. Does feedback matter? Practice-based learning for medical students after a multi-institutional clinical performance examination. Med Educ. 2007 Sep;41(9):857-65. Disponível em <https://www.ncbi.nlm.nih. gov/pubmed/17727526 > Acesso em 22 jul. 2019. 
WOOD, D. F. Problem Based Learning. British Medical Journal, 2003; 326-328. Disponível em <https://www.bmj.com/content/326/7384/328.full>. Acesso em 15 ago 2019.

\section{APÊNDICE - QUESTIONÁRIO - TUTORIA}

1- Qual sua opinião sobre o estudo prévio das matérias antes das aberturas de problema?

2- As mudanças neste último semestre, retirando o estudo prévio dos itens de avaliação como vinha sendo praticado, foram positivas? Em que medida?

3- Como você se sente sendo o relator do caso: dificuldades; atribuições como escrever na lousa; uso de tecnologia digital para o ensino e compartilhamento de conteúdo? Quais suas sugestões para essa função, visando a melhora do aprendizado (na abertura e no fechamento)?

4- Como você se sente sendo o coordenador do caso: dificuldades; relação com a função coordenadora do tutor? Quais suas sugestões para essa função, visando a melhora do aprendizado, na abertura e no fechamento?

5- Qual você julga ser a melhor maneira de se determinar os objetivos de estudo do problema? Dê opiniões e sugestões.

6- Discorra sobre a ansiedade nas tutorias, em relação à atuação do tutor; modelo de avaliação; importância em relação às outras áreas do curso (IESC; Habilidades; Morfofuncional...).

7- Qual sua opinião sobre a importância de o tutor ter bom domínio do assunto discutido? Como isso pode afetar a discussão e o aprendizado?

8- Em sua opinião, quais as características de uma tutoria ideal para o aprendizado (abertura e fechamento), no tocante ao: maior ou menor direcionamento e explicações do assunto por parte do tutor (tutor mais ativo ou 
Uก-

como eventual professor, quando oportuno ou necessário); métodos de avaliação?

9- Em sua opinião, quais as características de um tutor ideal? 


\section{FORMAÇÃO DO PROFESSORADO PAULISTA: Um estudo da Revista Escolar (1925 - 1927)}

PETTA, Thiago Teixeira de

\section{INTRODUÇÃO}

Esse trabalho tem por objeto o estudo da Revista Escolar (19251927), mais especificamente analisando como este como o periódico pensou e contribuiu com a formação do professorado paulista neste período. Neste texto buscamos identificar os ideários republicanos, que se formaram a partir das novas ideais científicas europeias que chegam ao Brasil, como o positivismo, o liberalismo e o ecletismo, constituindo a ideia de um cidadão completo e republicano, procurando entender como eles serviram de plano de fundo e escopo para a formação de um tipo ideal de docentes e consequentemente de alunato para a República.

A Revista Escolar foi publicada entre os anos de 1925 e 1927, contando com um total de 33 volumes, sendo de responsabilidade da Diretoria Geral da Instrução Pública de São Paulo. O periódico apresentava em suas edições "lições prontas" para serem usadas em sala de aula pelo professorado assinante. Este periódico teve significativa projeção, se levarmos em conta seu público, o professor recém-formado nas escolas normalistas, a venda e tiragem de 3.500 exemplares por volume. Teve seu fim em 1927 após a fusão com a revista Sociedade de Educação, tornando-se a revista Educação (NERY, 1993).

$\mathrm{Na}$ construção do trabalho, iremos abordar uma bibliografia especializada em Primeira República brasileira, tanto nos aspectos educacionais, quanto nos culturais, políticos e sociais. Em relação ao campo educacional traremos uma literatura focada na História da Educação e nos textos referentes aos periódicos educacionais. A fonte principal de investigação é a Revista Escolar, no qual trabalharemos com 32 dos 33 volumes que foram organizados, digitalizados e disponibilizados online pelo Arquivo Público do Estado de São Paulo1.

O trabalho com periódicos nos traz, primeiramente, uma grande gama de opções de trabalho por sua complexidade e por apresentar muito das discussões e disputas travadas em uma época (CATANI, 1996), no caso

\footnotetext{
${ }^{1}$ Só serão utilizadas 32 das 33 edições da revista pois a faltante não foi encontrada. Os 32 números podem ser acessados pelo site do Arquivo público do Estado de São Paulo. Disponível em: < http://www.arquivoestado.sp.gov.br/educacao/publicacoes.php>. Acesso em: 12 ago. 2019
} 
específico da Revista Escolar, iremos mostrar como se deu o embate entre a visão mais tradicionalista da revista e o movimento renovador da "Nova Escola". No entanto, esse tipo de estudo também requer certo cuidado, pois os periódicos trazem consigo uma carga de subjetividade que devem ser considerados em seu estudo (LUCA, 2005).

Em se tratando de um estudo histórico da educação, o trabalho com as revistas educacionais é relevante e nos ajudam a ampliar a concepção em torno das pautas e linhas abordagens da educação de uma época, compreendendo também as formas de organizações de sistemas escolares pretendidas por um grupo específico de educadores. Além deste tipo de fonte contar com uma grande interatividade, ou seja, um diálogo entre a sociedade da época, seja por meio de publicação em outros periódicos, ou por constate diálogo com a classe docente. De forma extensiva, este estudo adentra as pesquisas e reflexões em torno da Formação de Professores, visto que a fonte de investigação, a Revista funcionava também como um veículo de formação docente.

Assim, dividimos o texto em três tópicos denominados: "A efervescência educacional dos anos 20", no qual há uma breve contextualização história da situação educacional da década de 20; "Os Periódicos", apresenta o espaço que os periódicos ganham no século XX e um breve levantamento de revistas educacionais; "A Revista Escolar (1925 1927)" trata do nosso objeto de pesquisa em questão, trazendo uma descrição do periódico e uma análise sobre o embate entre a escola tradicionalista e a "Escola Nova", além de tentar entender a revista na formação docente.

\section{A EFERVESCÊNCIA EDUCACIONAL DOS ANOS 20}

A História educacional do Brasil no início do século $X X$ foi marcada por uma série de reformas e tentativas de formulações de um novo ideário educacional. A República brasileira conferia ao Império o pouco desenvolvimento da educação, introduzindo em seu discurso a promessa de um avanço do campo, que na prática não se concretizou; as mudanças profundas pretendidas na educação não foram materializadas (SAVIANI, 2007).

A República não se constitui com base popular, o caráter elitista do movimento republicano trouxe a necessidade de legitimação. O povo não assistiu a tudo bestializado, como atesta José Murilo de Carvalho em oposição a Aristides Lobo (CARVALHO, 1987), contudo ele não foi protagonista desse movimento. O Brasil entra na modernidade, os diversos debates travados no mundo ocidental adentram as terras tupiniquins e se faz presente a necessidade da construção de um homem moderno. Um homem capaz de FORMAÇÃO DO PROFESSORADO PAULISTA: Um estudo da Revista Escolar (1925 
dialogar e se fazer ativo diante desse mundo liberal nascente. Este processo está intimamente ligado à urbanização e ao modo de vida que a cidade grande proporciona (BUFFA, 2009).

Desde o começo do século ganha importância nuclear a questão a questão da formação cívica e moral, como base para o soerguimento de amplos quadros de nacionalidade - ideal de que formação que se prende ao ambiente de pessimismo que dominou o País pouco depois da proclamação da República, que de resto, significou o desgaste da ilusão da República-Educadora (NAGLE, 1974, p. 240).

Neste momento algumas perguntas começam a ser feitas, como: qual o tipo de sociedade queremos construir? Que tipo de povo queremos? Respostas começam a ser pensadas e todas as vitoriosas se espelham em um lugar, o velho mundo. Nasce então as teorias de branqueamento populacional, descritas tão bem por Lilian Schwartz (2001), o passado irracional da escravidão se faz presente e junto a ele a necessidade de superação, entretanto isso não é pensado e concretizado por políticas de reparações ou inclusão, mas com o apagamento e exclusão dos negros e pobres dessa sociedade. Outra pergunta, de grande importância para esse trabalho é: como formar um cidadão para viver nesse "novo" mundo? A resposta tanto para essa pergunta, quanto para a legitimação do novo sistema político, foi, além da imigração europeia, a educação. Para os republicanos por meio da educação seria possível transformar a sociedade brasileira e formar um homem mais "racional" e moderno.

É, agora, necessário esclarecer como esses grupos pensaram o problema da escolarização e, assim, renovarem o clima para o desenvolvimento do entusiasmo pela educação e do otimismo pedagógico. Uma das mais significativas formas de padrão de pensamento educacional, na década dos vinte, foi a de considerar a escolarização como o problema vital, pois a solução dele dependeria do encaminhamento adequado dos demais problemas da nacionalidade (NAGLE, 1974, p. 109).

Partindo para o campo educacional, a Reforma de Leôncio Carvalho2 (1879) é o primeiro eco dessas novas ideias, realizando a primeira tentativa de organização do ensino. Essa reforma buscou garantir à moralidade e higiene a sociedade. Outro ponto muito importante foi a liberdade de ensino, ou seja, o não monopólio do ensino por parte do Estado; mais tarde veremos como essa ação foi de suma importância para o desenvolvimento das escolas de formação docente.

\footnotetext{
${ }^{2}$ Carlos Leôncio de Carvalho nasceu em 18 de junho de 1847 na província do Rio de Janeiro. Se torna catedrático da Faculdade de Direito de São Paulo no ano de 1881 . Em 1878 se elege deputado e em 1879 realiza a reforma que reestrutura o ensino superior, secundário e primário. Dando origem aos pareceres de Rui Barbosa. Breve biografia de Leôncio. Disponível em: $<$ http://www.histedbr.fe.unicamp.br/navegando/glossario/verb b carlos leoncio de carvalho.htm>. Acesso em: 12 ago. 2019. Projeto da Reforma na integra. Disponível em <https://www2.camara.leg.br/legin/fed/decret/1824-1899/decreto-7247-19-abril-1879-547933publicacaooriginal-62862-pe.html>. Acesso em: 12 ago. 2019
} 
Por mais que o entusiasmo pela educação, no início da república, tenha sido muito forte, ele não conseguiu um pleno desenvolvimento, como enuncia Saviani:

E, apesar do entusiasmo que marcou o início do período republicano com a criação dos grupos escolares, até o final da Primeira República o ensino escolar permaneceu praticamente estagnado, como se vê pelo número de analfabetos em relação à população total, que se manteve em $65 \%$ entre 1900 e 1920, tendo seu número absoluto aumentado de 6348.869, em 1900, para 11.401.715, em 1920 (SAVIANI, 2007, p. 150).

E também a interrogativa do Diretor Geral da Instrução Pública, Oscar Thompson, em relatório no ano de 1918, em relação a esse problema:

\begin{abstract}
A evolução do ensino público paulista, já no que toca aos seus métodos educativos, já no que se refere à sua difusão por todos os 196 municípios do Estado, acresceu ao estudo de grandes e importantes problemas que exigem solução pronta e rápida: 232.621 crianças frequentaram escolas públicas em 1918; 247.543 em idade escolar não frequentaram escolas públicas ou particulares conforme atesta a estatística. Que fazer para educar esses milhares de menores que, crescendo analfabetos, constituirão elementos negativos do nosso progresso?" (NERY, 1993, p. 18).
\end{abstract}

O florescer dos anos 20 traz consigo debates intensos no campo educacional, uma efervescência das ideias pedagógicas (SAVIANI, 2007). Resultado de uma série de acontecimentos que emergia a sociedade brasileira, entre elas, a derrocada das oligarquias e ascensão de novos agentes sociais, o proletariado e a burguesia. Como consequência, o movimento de renovação educacional parte dessa nova elite dominante, que segundo Jorge Nagle seria o movimento da "Nova Escola" o liberalismo na educação (NAGLE, 1974), ou seja, a burguesia como agente transformador e educador (NERY, 1993).

Diversas reformas se configuram nos anos 20, mas a de Sampaio Dória (1920) foi a que mais marcou esse período de renovação. Adepto do "escolanovismo", Dória elegeu o analfabetismo como um dos principais problemas na educação brasileira, profissionalizou o magistério e buscou 0 desenvolvimento político, econômico e social por meio da educação (HONORATO, 2017). Outro ponto fundamental desse texto foi a popularização da educação, em que "Sampaio Dória, planejava republicanizar a República tendo a instrução popular como forte bandeira em nome do progresso, consciência eleitoral e justiça." (Ibid, p. 1282), lembrando que uma das restrições de exercício ao voto na constituição de 1891 foi a alfabetização3. Este mote se torna um dos centros do debate ao longo dos anos 20.

No qual Saviani conclui:

\footnotetext{
${ }^{3}$ Ver o artigo 70, 1 da constituição federal de 1891. Disponível em:

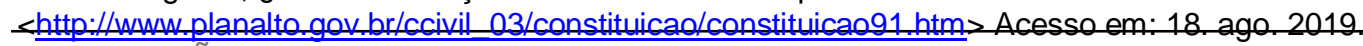


Em suma, as primeiras décadas do século XX caracterizam-se pelo debate das ideias liberais sobre cuja base se advogou a extensão universal, por meio do Estado, do processo de escolarização considerando o grande instrumento de participação política. É pois, a ideias central da vertente leiga da concepção tradicional, isto é, transformação, pela escola, dos indivíduos ignorantes em cidadão esclarecidos, que esteve na base do movimento denominado por Nagle (1974) de "entusiasmo pela educação", o qual atingiu seu ponto culminante na efervescente década de 1920 (SAVIANI, 2007, p. 177).

No contexto da efervescência, as ideias "escolanovistas" adentram o jogo político da educação em contraste à escola tradicional, aquela caracterizada pelos grupos escolares. O embate entre essas duas linhas se dá em diversos aspectos da sociedade educacional em questão, desde o meio acadêmico, até o meio parlamentar e jornalístico. Há nesse momento uma disputa política que adentra ao campo educacional (NAGLE, 1974).

Já em 1925 temos a Reforma da instrução pública no Estado, em que para alguns contemporâneos, por mais que tenha sido uma reforma profunda no campo administrativo, foi um grande retrocesso em relação à reforma de 1920 no que tange ao movimento de renovação "escolanovistas". Essa reforma, no campo institucional garantiu a formação da Revista Escolar, ou seja, o periódico nasce com o conflito entre a escola tradicionalista versus a "Escola Nova" (NERY, 1973).

No que tange a Formação de Professores, um dos objetivos principais desse trabalho, a liberdade educacional firmada pela Reforma de Leôncio Carvalho teve grande papel na constituição de escolas normais, pois o sistema público de escolas de formação docente era muito escasso, ficando a cargo das instituições privadas grande parte da formação do professorado.

Também importante para a expansão do Ensino Normal foi a introdução de escolas normais de iniciativa privada e municipal, qualificadas de livres ou equiparadas, com o que se procurava compensar a escassez de estabelecimentos oficiais na maioria dos estados (TANURI, 2000).

A efervescência dos anos 20 realiza uma grande transformação nas escolas de formação docente. As antigas não respondem nem ao currículo escolar e nem mesmo ao grau de exigência que surge. Há uma profissionalização do ensino. A importância que a escola ganhou levou a necessidade de um professorado mais capacitado para sua nova função. Tanuri após citar Jorge Nagle, conclui:

As críticas já antigas sobre o reduzido caráter profissional das escolas normais e a predominância dos estudos de cultura geral em seu currículo ganhavam maior ênfase, num momento em que a "nova" orientação do ensino requeria conhecimentos sobre o desenvolvimento e a natureza da criança, os métodos e técnicas de ensino a ela adaptados e os amplos fins do processo educativo (IBID, p. 70). 
"escolanovistas":

Outro ponto, levantado por ela, diz respeito as ideias

Por volta do final dos anos 20 , as escolas normais já haviam ampliado bastante a duração e o nível de seus estudos, possibilitando, via de regra, articulação com o curso secundário e alargando a formação profissional propriamente dita, graças à introdução de disciplinas, princípios e práticas inspirados no escolanovismo, e a atenção dada às escolas-modelo ou escolas de aplicação anexas (IBID, p.72).

Fizemos até o presente momento uma pequena contextualização histórica do objeto a ser trabalhado por nós, a Revista Escolar, e foi possível observar um grande acirramento das questões postas ao fim do Império, em meados dos anos 20. Como enuncia Fabiana Silva Fernandes e Moysés Kuhlmann Jr, citando Willians, Cruz, Peixoto e De Luca.

\begin{abstract}
A análise de um periódico não pode tomar a fonte como se fosse um sujeito histórico, independente das pessoas reais e das tensões existentes nas relações sociais em que se produzem os discursos e os bens culturais. Entende-se que é necessário situar o impresso como fonte de pesquisa no interior da história social, evitando-se tratar isoladamente a dimensão cultural, o que requer a busca de articulações com a história mais ampla, ou seja, os movimentos sociais e políticos, a conjuntura histórica do período da publicação e os movimentos e formações sociais em relação aos quais uma determinada publicação se articula de modo mais específico (FERNANDES; KUHLMANN, 2012, p. 565).
\end{abstract}

Ou seja, é de suma importância localizar o objeto em seu contexto de conflitos e embates, pois assim há a possibilidade uma compreensão mais ampla do periódico.

\title{
3. OS PERIÓDICOS
}

O século $X X$ traz consigo o modo de vida urbano, a modernização se torna o principal mote dessa sociedade, mesmo sendo predominantemente rural, que começa a ser estruturada com base no setor industrial e o nascente setor de serviços. As relações e os símbolos ganham ressignificações com esse "novo mundo", assim como os hábitos. A informação se torna muito importante, pelo fato da dinamicidade e da velocidade que essa sociedade toma. Com isso, a indústria dos periódicos é racionalizada, os processos que antes eram manuais, tornam-se mecanizados. Isso implica diretamente no produto final, pois ao mudar o processo produtivo do periódico, muda-se 0 público alvo, a periodização, por conseguinte, o volume de seu conteúdo (CRUZ, 2000). 
As classes letradas são as principais usuárias dos periódicos, tanto em relação ao ler, quanto ao escrever. As notícias, a crítica e o conhecimento tornam-se um canal abrangente e veloz. Para Ana Cristina Rodrigues:

A indústria dos periódicos torna-se tão atrativa à classe letrada quanto os utensílios e ferramentas que facilitariam o seu trabalho. Por meio dos periódicos impressos as notícias também ganham o desejo pela velocidade pulsante das cidades e pela transparência da vida política, econômica e social das cidades, estados e países, incluindo a do próprio Brasil. Os periódicos em suas diversas cores e tamanhos, ao informarem seus leitores e os frequentadores de ambientes onde eram lidos para grupos de ouvintes, instigavam a curiosidade das pessoas e o desejo por mais informações, além de propiciarem a discussão a respeito dos assuntos ali contidos. A indústria periódica cria um novo saber e uma nova cultura dentro do ambiente urbano e escolarizado (RODRIGUES, 2014).

Essa expansão editorial, conferiu aos periódicos um novo status de maior projeção e consequentemente maior importância. As revistas e jornais passam a receber um pesado investimento, sendo responsáveis por legitimar e dar credibilidade a determinados grupos. As novas relações sociais e institucionais começam a ser divulgadas e propagandeadas a partir desses novos meios que só cresciam dentro da sociedade. $O$ crescimento vertiginoso dos periódicos no século XX abre espaço a uma grande aquarela de publicações, entre elas as revistas educacionais. Sobre essa renovação e expansão do campo:

Escrever a história da educação de um outro modo: menos centrado no papel do Estado ou dos grandes pedagogos e mais atento à riqueza das iniciativas locais, institucionais, ideológicas, sócioprofissionais e também ao atendimento de expectativas de vez que, diferente do livro, a imprensa periódica é uma mídia interativa na orientação da qual os leitores participam de um modo ou de outro, quer escrevendo para ela, quer assinado-as ou deixando de fazê-lo (CATANI, 1996, p. 117).

Devemos entender os periódicos educacionais, como um alargamento do campo de ensino. A construção do saber, as reinvindicações da classe docente, as novidades no campo de ensino, as disputas sociais e profissionais, todos esses aspectos do ensino começam a ser veiculados por essas revistas, ou seja, as questões educacionais auferem maior voz e consequentemente, maior visibilidade. O periódico se torna por si próprio um objeto de pesquisa e não um mero auxiliador do trabalho historiográfico (LUCA, 2005). A partir dessas fontes, tão abundantes, conseguimos analisar diversos nuances e perspectivas históricas na educação.

Nas últimas décadas ocorreu considerável expansão em trabalhos com os periódicos educacionais, o campo historiográfico tem tratado deste tipo de fonte, relativamente nova ao trabalho do historiador, visando compreender movimentos, disputas e as particularidades regionais da educação. Isso só 
evidencia a necessidade de maior aprofundamento de trabalhos com estas fontes, pois, a partir deles, surgem novos questionamentos e análises.

Por conta do café, São Paulo se torna o símbolo do desenvolvimento brasileiro, consolidando-se no decorrer do século XX como polo irradiador da modernização. Com isso, a classe letrada também se moderniza e consequentemente os periódicos educacionais no estado ganham muita projeção. Dentre os sistemas de ensino, São Paulo é tomado como modelo, constituindo uma classe docente melhor formada e consequentemente mais ativa nos debates sobre o campo educacional. Com o campo editorial em ascensão, ele se torna o meio perfeito para divulgação das questões referentes a educação, em especial as revistas educacionais. Dentre elas, cito a Eschola Pública (1893 - 1897), São Paulo; Revista Jardim da Infância (1896 - 1897), São Paulo; Educação (1902 - 1903), São Paulo; Revista de Ensino (1902 1919), Associação Beneficente do Professorado Pública de São Paulo/ Diretoria Geral da Instrução Pública, São Paulo; Revista de Educação (1921 1922), Piracicaba; Revista da Sociedade de Educação (1923 - 1924), São Paulo; Revista Escola (1925 - 1927), Diretoria Geral da Instrução Pública, São Paulo. Educação (1927 - 1930), Diretoria Geral da Instrução Pública, São Paulo.

Em relação aos estudos historiográficos sobre as revistas educacionais, cito: "Educadores à meia-luz: Um estudo sobre a Revista de Ensino da Associação Beneficente do Professorado Público de São Paulo (1902-1918)", Denice Barbara Catani; "O Novo e o Nacional em Revista: a Revista do Ensino do Rio Grande do Sul (1939-1942)", Maria Helena Bastos; "A Revista Escolar e o Movimento de Renovação em São Paulo" e "A Sociedade de Educação de São Paulo: embates no campo educacional (1922- 1931)", Ana Clara Bortoleto Nery; "A educação do corpo nas páginas da Revista Escolar (1925- 1927)", Ana Cristina Rodrigues; "O impresso como estratégia de formação de professores(as) e de conformação do campo escolar em Minas Gerais: o caso da Revista do Ensino (1925-1940)", Maurilane de Souza Biccas; "Educação física na Revista do Ensino de Minas Gerais (1925-1935): organizar o ensino, formar o professorado", Tarcísio Mauro Vago. Esses são apenas alguns dos trabalhos que julguei mais importantes na construção deste texto. As discussões e consequente as questões levantas por eles contribuíram muito para a constituição de um campo de estudo mais sólido sobre o tema.

\section{A Revista Escolar (1925 - 1927)}

A Revista Escolar foi um periódico mensal impresso pela Diretoria Geral da Instrução Pública, publicada entre janeiro de 1925 e setembro de FORMAÇÃO DO PROFESSORADO PAULISTA: Um estudo da Revista Escolar (1925 - 1927) - pp. 55-69 
1927, contando com 33 edições, contudo iremos trabalhar apenas 32 delas. Foi organizada, digitalizada e disponibilizada online pelo Arquivo Público do Estado de São Paulo ${ }^{4}$. O periódico é composto por uma série de "lições prontas" para uso do professor em sala de aula, metodologias de ensino, palestras e notícias sobre novas diretrizes educacionais. Ao que tange a redação:

[...] era formada por um redator-chefe e dois redatores auxiliares. Como redator-chefe tivemos João Pinto e Silva que, curiosamente também era membro da Sociedade de Educação e que posteriormente passou a ser redator da revista Educação permaneceu no cargo do início ao fim da publicação. Entre os auxiliares tivemos José Veiga, Alduíno Estrada, Augusto Ribeiro de Carvalho e Antônio Faria que se revezaram ao longo da publicação (NERY, 2001, p. 8).

A revista se divide em tópicos, nos quais os mais frequentes são: "Lições Práticas" - responsável por apresentar lições prontas aos professores para uso em sala de aula, subdividida em temas como geografia, educação moral, educação cívica, geometria e etc.; "Lições de Coisas" - esse tópico apresentava um grande leque de conteúdo, desde explicações sobre o uso da agua até a importância de não andar descalço; "Questões Gerais" - esse tópico era composto por palestras de ensino e conteúdos aleatórios que não eram abarcados pelos outros tópicos; "Literatura Infantil" - apresenta diversos textos infantis para serem usados em sala de aula, muitos de cunho moralizantes. Além desses tópicos, muitos outros estavam contidos nos volumes da revista, entretanto, não com a recorrência destes acima citados.

Por se tratar de uma publicação oficial e receber verba pública, a revista conseguiu ter uma grande projeção no debate educacional da época, chegando a uma tiragem de cerca de três mil exemplares, um número grande se considerarmos seu público específico, o professorado paulista. Contudo não podemos cair na análise simplista de considerar estes os únicos fatores de seu relativo sucesso. Quando a revista muda seu formato, em 1927, adotando uma linha mais filosófica, perde-se grande parte de suas assinaturas, ou seja, as lições prontas presentes no periódico foram um de seus grandes chamarizes.

As lições consistem em perguntas e respostas, modelos para serem copiados e usados em aula com uma temática muito variada. $O$ periódico vai se dedicar a um professorado recém-formado, sem muita experiência. A partir disso pode ser explicada sua apresentação simplificada e basilar.

Sua criação se deu no ano de 1925, em decorrência da Reforma da Instrução Pública. Evento substancial para o entendimento do periódico. Se

\footnotetext{
${ }^{4}$ Só será utilizado 32 das 33 edições da revista pois a faltante não foi encontrada. Os 32 números podem ser acessados pelo site do Arquivo público do Estado de São Paulo. Disponível em: < http://www.arquivoestado.sp.gov.br/educacao/publicacoes.php $>$. Acesso em: 12 ago. 2019
} 
trata de uma reforma muito profunda, no qual se considerarmos a de Sampaio Dória, muito mais intensa no campo administrativo, mas tratando do caráter pedagógicos, reacionária. Especificamente em relação ao campo pedagógico ela representa um reavivamento do Grupos Escolares e tudo que eles representavam.

O método intuitivo é revalorizado, por conseguinte as "lições de coisas". Na Revista Escolar este tópico aparece em seus 33 exemplares.

[...] servir-se-á do método indutivo demonstrativo e objetivo, e basearse-á na experimentação, nas afirmações científicas e racionadas, para que os alunos tenham uma idéia clara do que Ihes quer ensinar. Educação Artística, Intelectual e Moral - conhecimento de tudo quanto nos rodeia; conhecimento das ciências e das artes; sentimento do belo, do verdadeiro e do real; desenvolvimento e compreensão sem esforço e por iniciativa própria. Matérias: as matérias a serem iniciadas, segundo alcance das faculdades de cada aluno, constarão de leitura, caligrafia, gramática, aritmética, geometria, geografia, botânica, zoologia, mineralogia, física, química, fisiologia, história, desenho, etc (HILSDORF, 2011, P. 75)

No que diz respeito ao nacionalismo, moral e civismo temos como exemplo o escotismo, tema muito recorrente na revista. No Brasil o movimento ganhou força com a criação da Liga de Defesa Nacional, que se configura com a eclosão da Primeira Guerra Mundial. Sua fundação ocorre no dia 7 de setembro de 1916, coma iniciativa de Pedro Lessa, Olavo Bilac e Miguel Calmon. Além do escotismo, muitas de suas ideias são veiculadas pela revista, por exemplo, o civismo, a História do Brasil cultuando os heróis nacionais civismo e etc.

De acordo com seus Estatutos, a Liga "independentemente de qualquer credo político, religioso ou filosófico, está destinada, dentro das leis vigentes do País, a congregar os sentimentos patrióticos dos Brasileiros de todas as classes". Esse objetivo geral é desdobrado num conjunto de objetivos menos gerais, tais como os seguintes: manter a idéia e coesão e integridade nacional; defender o trabalho nacional; difundir a instrução militar nas diversas instituições; desenvolver o civismo, o culto do heroísmo, fundar a associação de escoteiros, linhas de tiro e batalhões patrióticos; avivar o estudo de História do Brasil e das tradições brasileiras; promover o ensino da língua pátria nas escolas estrangeiras existentes no País; propagar a educação popular e profissional; difundir nas escolas o amor à justiça e o culto do patriotismo; combater o analfabetismo (NAGLE, 1974, p.45).

$\mathrm{Na}$ efervescência dos anos 20, como já descrita no primeiro tópico, se acirra o conflito entre a escola tradicionalista e a "Nova Escola". Como os periódicos são um campo de disputas, esse conflito também adentra suas páginas. A Revista Escolar, nasce da reforma de 1925, que é uma clara oposição à Reforma de Sampaio Dória (1920), ou seja, a revista já nasce com uma inclinação à escola tradicional e o método intuitivo, com suas "Lições de 
Coisas". A escola nova representava uma transplantação de um método estrangeiro, à realidade brasileira.

Para a solução desses problemas (educacionais) estariam apresentando modelos das instituições e métodos desenvolvidos nos países onde o escola-novismo estaria se desenvolvendo. E mais, deixando de considerar a própria realidade brasileira, sem ao menos pensar na hipótese de adequar esses modelos estrangeiros ao nosso meio (NERY, 1993, p. 44).

Entretanto no editorial da revista de número 25 no ano de 1927 ela muda o tom em relação à Escola Nova

A Escola Nova, que tão brilhantemente traduz a evolução da ciência do ensino, proclama agora a Cultura Activa destinada a desenvolver, em toda plenitude, o eu da criança, isto é, a cultivar-lhe a individualidade ao controle de suas inclinações, tendências, vocações, etc. (...) Procura, enfim, desenvolver-Ihe as atividades, para a vida consciente, e sorte que os fatos mentais se realizem à égide de reflexão clara, dum raciocínio seguro. (Revista, número 25 p.1)

Para Ana Clara Nery: "É a partir desta edição que a Revista Escolar assumiu uma postura clara a respeito da Escola Nova. Anteriormente alguns princípios escola-novistas estavam expressos em alguns artigos, mas de forma implícita." (NERY, 1993). Culminando, no ano de 1927, com a fusão entre a Revista Escolar e a Revista da Sociedade da Educação, tornando-se a Revista Educação.

Após essa fusão observamos uma queda nos números de assinantes da revista, o qual sugere uma recusa do professorado assinante a nova formatação do periódico, em que ao ver dos professores tinha se tornado muito filosófica (IBID).

Um excerto dessas lições prontas com o tema "Educação Cívica" contido na revista de número 22, publicada em outubro de 1926 exemplifica muito bem alguns pontos levantados até o momento:

Proefessor. - Você leu muito bem, Julio. Vamos agora conversar a respeito dessa linda poesia, procurar entendel-a bem. Quem a escreveu?

Alumno. - Foi Olavo Bilac.

P. - Sim, foi nosso patrício Olavo Bilac, o poeta-patriota, ou melhor, o patriota-poeta.

Repita a primeira linha, o primeiro verso dessa bela poesia.

A. $\quad-$ Ama, com fé e orgulho, a terra em que nasceste...

P. - Qual será essa terra em que nascemos, que o poeta nos incita, nos convida a amar?

A. - É o Brasil.

P. - Como sabe?

A. - Porque ele diz: - em que nasceste, e nós nascemos no Brasil.

P. - Porque acha você, Alvaro, que devemos amar o Brasil?

A. - Porque é a nossa Pátria.

A. - É a nossa mãe. 
A. - Porque aqui nascemos e vivemos

A. - Gozamos as suas belezas e as suas riquezas.

[...] (REVISTA ESCOLAR, no 25, 1926, p. 1)

Junto ao poeta Olavo Bilac, já citado por sua participação na fundação da Liga de Defesa Nacional, é possível observar o nacionalismo e civismo, além do modelo em que se estrutura todas as outras lições contidas no periódico. Essa é só uma pequena parte de uma lição, das centenas, veiculadas pela revista. Mas deixa diversos aspectos evidentes, como o seu caráter didático, com diálogos entre aluno e professor.

Na editoração de sua primeira edição a revista escolar deixa claro seus objetivos:

[...] a REVISTA ESCOLAR espera poder contribuir effizcamente para o aperfeiçoamento do ensino público paulista. Ella aguarda, pois, com prazer, colaborações de caracter didático, informações pedagógicas, instrucções, esclarecimentos, emfim todo e qualquer trabalho que se harmonize com a sua natureza e os seus fins (IBID, 1926).

Não entraremos no juízo de valor dessas lições ou do seu teor higiênico, nacionalista, moral e cívico e etc. Contudo, esses ideários nos dão um "plano de fundo" histórico muito importante para percebemos a relação que se constituiu entre a Revista Escolar e o professorado, no qual é possível um entendimento do tipo específico de docente se buscava formar e consequentemente a sociedade que se pretendia construir. A maior exigência, por exemplo, dos currículos das escolas normais aponta para esse caminho, a formação de um "cidadão completo".

\section{CONSIDERAÇÕES FINAIS}

Para concluir, enfatizamos a importância do estudo para a compreensão da História da Educação, mais precisamente a Formação de Professores, além da apreensão de diferentes elementos constituintes das políticas educacionais no Brasil, nesse caso o republicano. $O$ uso de periódicos como um auxiliar da formação docente pode ser verificado desde o final do século XIX, no Brasil, e a construção de questionamentos sobre esse tipo de estratégia formadora é muito importante e acrescenta com a área.

A Revista Escolar, ao vincular suas lições prontas, carregadas com alto teor de civismo, patriotismo, higiene, demostra o tipo de professorado que o grupo dirigente da revista, a Direção Geral da Instrução Pública, queria formar. Consequentemente, com a ideia que a república tinha de educação, que era a de transformadora da realidade social, esses ideários são fundamentais para o projeto republicado de Brasil. 


\section{REFERÊNCIAS}

BASTOS, Maria Helena C. O Novo e o Nacional em Revista: A Revista do Ensino do Rio Grande do Sul (1939-1942). São Paulo, FEUSP, 1994, tese de doutoramento.

Espelho de Papel: a imprensa e a história da educação. In: José Carlos Souza Araujo; Décio Gatti Junior. (Org.). Novos Temas em História da Educação brasileira: Instituições escolar es e educação na imprensa. 1ำ ed. Campinas-SP/Uberlândia-MG: Autores Associados/EDUFU, 2002,v., p. 151-174.

BICCAS, Maurilane de Souza. O impresso como estratégia de formação de professores(as) e de conformação do campo escolar em Minas Gerais: o caso da Revista do Ensino (1925-1940). Tese (Doutorado em Educação) Faculdade de Educação, Universidade de São Paulo, São Paulo, 2001.

Impresso pedagógico como objeto e fonte para historiografia em Minas Gerais: o caso da Revista do Ensino (1925-1940). In: CONGRESSO MINEIRO DE HISTÓRIA DA EDUCAÇÃO, São João Del Rei, maio 2005. (Palestra).

BUFFA, Ster. O Público e o Privado na Educação Brasileira do Século XX. In: BASTOS, Maria H Camara; STEPHANOU, Maria. (Orgs.). Histórias e Memórias da Educação, vol III: século XX. Petrópolis: Vozes, 2009.

CARVALHO, José Murilo de. Os bestializados - o Rio de Janeiro e a República que não foi. São Paulo: Cia. das Letras, 1987.

CATANI, Denise Barbara. A imprensa periódica educacional: a Revista de Ensino e o ensino do campo educacional. Revista Educação e Filosofia. v. 10. № 20, p. 115-130, Jul/Dez, 1996.

. Educadores à meia-luz: Um estudo sobre a Revista de Ensino da Associação Beneficente do Professorado Público de São Paulo (19021918). Bragança Paulista, SP: EDUSF, 2003.

CRUZ, Heloisa de Faria. São Paulo em Papel e Tinta: periodismo e vida urbana. 1890 - 1915. São Paulo, Educ/Fapesp/Arquivo do Estado de São Paulo/Imprensa Oficial SP, 2000.

FERNANDES, Fabiana Silva; KUHLMANN JR, Moysés. Análise de periódicos na história da educação: princípios e procedimentos. Caderno de Pesquisa. V. 42, № 145, p. 562-585, Maio/Agosto, 2012.

HILSDORF, Maria Lucia Spedo. História da educação brasileira: Leituras. São Paulo, Cengage Learning, 2011. 
HONORATO, Tony. A reforma Sampaio Dória: professores, poder e figurações. Educação e Realidade. Porto Alegre, v.42, n. 4, p. 1279-1302, out/dez. 2017.

LUCA, Tânia Regina de. Fontes Impressas: história dos, nos e por meio dos periódicos. In: PYNSKY, Carla Bassanezzi (Org). Fontes Históricas. São Paulo: Editora- Contexto, 2005.

NAGLE, Jorge. Educação e Sociedade na Primeira República. São Paulo: EDUSP. 1974. p. 240.

NERY, Ana Clara Bortoleto. (In)formando, divulgando e educando: uma década de imprensa periódica em São Paulo. Anais do V Seminário Internacional de Estudo e Pesquisa HISTEDBR. UNICAMP. Campinas, SP: Agosto, 2001.

A Revista Escolar e o movimento de renovação em São Paulo (1925 - 1927). Dissertação (Mestrado em Educação). Programa de PósGraduação Stricto Sensu em Educação, Universidade Federal de São Carlos, São Carlos, SP: UFSCAR, 1993.

NUNES, Clarice; CARVALHO, Marta. M. C.. Historiografia da educação e fontes. Cadernos da ANPED, Belo Horizonte, n. 5, p. 7-64, set. 1993.

Revista Escolar. Orgam da Directoria da Instrucção Publica. Publicação Mensal. São Paulo, SP. Brasil, 1925 - 1927. Disponíveis em: ARQUIVO PỦBLICO DO ESTADO DE SÃO PAULO. Disponível em: <http://www.arquivoestado.sp.gov.br>. Acesso em: 26 ago. 2019.

RODRIGUES, Ana Cristina. A educação do corpo nas páginas da Revista Escolar (1925- 1927) Itatiba, 2014. Universidade São Francisco. 132 p. (dissertação de mestrado).

SAVIANI, Dermeval. História das Idéias Pedaógicas no Brasil. Campinas: Autores Associados, 2007.

SCHNEIDER, Omar. A revista Educação Physica: a arqueologia de um impresso. Vitória: Edufes, 2010.

SCHWARCZ, Lilia Moritz. O Espetáculo das raças - cientistas, instituições e questão social no Brasil (1870-1930). São Paulo: Cia das Letras, 2001 [1993].

SOUZA, Rita de Cássia. A Revista do Ensino e a disciplina escolar em Minas Gerais (1925-1930). Dissertação (Mestrado em Educação) - Faculdade de Educação, Universidade Federal de Minas Gerais, 2000.

TANURI, Leonor Maria. História da formação de professores. Rev. Bras. Educ., Rio de Janeiro, n. 14, p. 61-88, Ago. 2000. Disponível em $<$ http://www.scielo.br/scielo.php?script=sci_arttext\&pid=S1413-

$24782000000200005 \&$ Ing=en\&nrm=iso>. Acesso em: 16 de ago. 2019. 
TOLEDO, M.R.A. Coleção atualidades pedagógicas: do projeto político ao projeto editorial (1931-1981). (Tese Doutorado). Pontifícia Universidade Católica de São Paulo, 2001.

VAGO, Tarcísio Mauro. Educação física na Revista do Ensino de Minas Gerais (1925-1935): organizar o ensino, formar o professorado. Revista Brasileira de História da Educação. № 11, p. 101-134, Jan/Jun, 2006. 


\title{
O ENSINO DA LÍNGUA PORTUGUESA: A importância do estágio supervisionado na busca por novas abordagens de ensino
}

\author{
FACIROLI, Ana Lívia Guimarães \\ Graduanda em Letras/Inglês - Uni-FACEF \\ analiviagf10@gmail.com \\ VIEIRA, Giovana Flávia \\ Graduanda em Letras/Inglês - Uni-FACEF \\ giovanavieira51@gmail.com \\ ALVES, Maria Sílvia Rodrigues \\ masilrodriguesalves@gmail.com
} Doutora em Linguística e Língua Portuguesa - Uni-FACEF

\section{INTRODUÇÃO}

Segundo os Parâmetros Curriculares Nacionais e a Base Nacional Comum Curricular, o ensino da Língua Portuguesa nas escolas brasileiras tem como objetivo a possibilidade de que o estudante consiga, através da linguagem, a aquisição de conhecimentos sobre a cultura em que está inserido, assim como a utilização da língua falada em diversas circunstâncias dentro das várias esferas de atividades humanas da comunidade linguística.

Para isso, diversas abordagens de ensino podem ser empregadas ao ensinar a Língua Portuguesa. Dessa forma, nesta pesquisa fizemos uso dos estudos de duas dessas metodologias de ensino: a tradicionalista e a construtivista.

Mesmo que outras metodologias existam, a tradicionalista ainda é a mais recorrente em grande parte das escolas brasileiras, portanto, esta pesquisa teve como objetivos apresentar o funcionamento das duas abordagens e ressaltar suas principais características, mostrando, desta forma, algumas vantagens encontradas no uso do método construtivista, no âmbito da formação de conhecimento do estudante e em relação aos recursos pedagógicos que podem ser empregados pelo professor.

Para tanto o referencial teórico-metodológico utilizado foi uma revisão bibliográfica dos estudos de Mizukami (1986), Piaget (1975) e Elias (1992) sobre as metodologias. Fizemos uso, também, dos Parâmetros Curriculares Nacionais (PCNs) e da Base Nacional Comum Curricular (BNCC) 
para tratar do ensino da Língua Portuguesa, assim como os estudos de Pimenta (1994) sobre o estágio supervisionado.

\section{O ENSINO TRADICIONALISTA X O ENSINO CONSTRUTIVISTA}

Ao longo da história da educação, várias abordagens de ensino foram criadas e cada uma delas sofreu influências de diferentes teóricos, realizando assim, os seus posicionamentos didáticos. Neste artigo, usamos duas abordagens de ensino, a abordagem tradicional e a abordagem construtivista, a partir dos estudos da professora Maria da Graça Nicoletti Mizukami (1986), de Jean Piaget (1975) e de Marisa Del Cioppo Elias (1992).

A abordagem tradicional trata de práticas educacionais que persistem no tempo em suas diferentes formas, além de ter influenciado outras abordagens. Nela, o adulto é considerado um homem "acabado", ou seja, já formado, e a criança um adulto em formação, aquele que precisa de "atualizações". Sendo assim, o ensino é centralizado no professor e o aluno apenas executa as ações que lhe são mandadas por autoridades exteriores. Dessa forma, a relação professor-aluno é vertical, sendo que o professor detém o poder decisório quanto à metodologia, conteúdo, avaliação, forma de interação na aula etc.

Nesta abordagem, o mundo é algo que transmite informações através da educação formal, da família ou da religião. O homem é apenas um inserido no mundo, que recebe essas informações e quando já as possui, pode repeti-las para outras pessoas que ainda não possuem tais informações.

Essas informações e conhecimento estão diretamente ligados à cultura da sociedade em que o homem está inserido. $\mathrm{Na}$ abordagem tradicional, o conhecimento do aluno é testado a partir de provas e exames. É onde se realiza a avaliação, em que é necessário que o aluno tenha o mínimo de conhecimento cultural, caso contrário, é reprovado. A partir disso, o diploma é considerado um instrumento de hierarquização.

Partindo do pressuposto que a inteligência seja uma faculdade capaz de acumular/armazenar informações, o conhecimento, que são as informações mencionadas no início, terá de ser memorizado pelos alunos, uma vez que, deste processo é mostrado apenas o resultado. Ou seja, o ensinoaprendizagem nessa abordagem se preocupa mais com a variedade e quantidade de noções/conceitos/informações do que com a formação do pensamento reflexivo.

A educação é entendida como uma transmissão de conhecimento restrita à escola e para que o aluno tenha acesso a esses conhecimentos, de 
forma favorável, é necessária a intervenção de um professor. A escola, como já dito, é onde se realiza a educação em sala de aula. O ato de aprender é considerado uma cerimônia, na qual é fundamental uma distância entre professores e alunos.

Quanto à metodologia o professor já traz o conteúdo pronto e o aluno se limita exclusivamente a escutá-lo, ou seja, se baseia na aula expositiva e nas demonstrações do professor à classe, tomada quase como um auditório. No método expositivo como atividade normal, está implícito o relacionamento professor-aluno, no qual o professor é o agente e o aluno é o ouvinte. O trabalho continua mesmo sem a compreensão do aluno. Em relação ao atendimento individual há dificuldades, pois a classe fica isolada e a tendência é de se tratar todos igualmente.

Já a abordagem construtivista se estabelece pela interação do sujeito com o meio físico e social, ou seja, é a combinação daquilo que o organismo traz e a conjuntura oferecida pelo meio. Neste estudo, o professor é um mediador do conhecimento que o estudante já tem, dando condições para que ele vivencie métodos e atividades interativas para, assim, construir os próprios saberes.

A interação com o meio se dá a partir de dois processos: a adaptação ao meio e a organização interna. A adaptação ocorre por meio da assimilação (busca do entendimento de algo desconhecido por meio do próprio conhecimento prévio, assimilando até descobrir o que é) e da acomodação (ao fazer as assimilações, o sujeito altera o objeto em busca do entendimento e a acomodação consiste nessas mudanças).

$\mathrm{Na}$ prática do ensino construtivista, o professor deve levar em consideração os processos de assimilação da criança, fornecer atividades desafiadoras que provoquem desequilíbrio para que aconteça a construção do conhecimento. É necessário que a escola reconheça que as hipóteses feitas pela criança são adquiridas pelo meio. Dessa maneira, o conhecimento do educando não é simplesmente transmitido pelo professor, mas é um resultado da interação na qual professor e aluno são ativos.

Criando situações problemáticas estará permitindo o surgimento de momentos de conflito para o alfabetizando e, consequentemente, 0 avanço cognitivo; estará considerando o aprendiz como um ser ativo, aquele que não espera passivamente que alguém venha lhe ensinar alguma coisa para começar a aprender, uma vez que por si só compara, ordena, classifica, reformula e elabora hipóteses, reorganizando sua ação em direção à construção do conhecimento. (ELIAS, 1991. p.50)

Assim, compreende-se que o papel do professor é mediar o conhecimento, propiciar a interação com e entre os estudantes. Além disso, é 
vital que o professor tenha consciência do que faz, entendendo sua posição de mediador e não de transmissor, estudando as características de aprendizagem dos alunos.

A metodologia construtivista mostra que as técnicas de leitura e de escrita deverão ter um norte diferente do que tinha, pois não seguiam a proposta construtivista. Diferente do ensino tradicional, os estudantes poderão entender o porquê aprender de tal maneira, o professor não somente aplica técnicas de leitura e escrita, mas também ensina o porquê ler e escrever. Escrever e ler não são um meio, é uma finalidade, têm sua importância única.

Ademais, para estimular e facilitar as descobertas da aprendizagem, o ideal é ter salas com menos alunos na escola e, de preferência, organizadas em círculos. Dessa maneira, o professor pode acompanhar de perto as situações de cada aluno, adaptar sua metodologia para cada caso e, ainda, permitir que haja mais interação e a participação dos alunos. Assim, aumenta a possibilidade de melhor interação com outras turmas e ambientes.

Evitar interferências também é importante pois, sendo um mediador e motivador, o professor deve entender que cada educando possui seu processo de aprendizado, uns mais lentos que os outros, e, por esse motivo, propõe diferentes maneiras de aprender determinado conteúdo.

O método de avaliação também é diferenciado. No método construtivista não existem testes e provas para observar se o aluno aprendeu 0 conteúdo. Considerando que 0 professor acompanha de perto 0 desenvolvimento do aluno na sala de aula, as provas não são necessárias. São aplicadas apenas provas diagnósticas, para que o professor entenda as dificuldades específicas de cada aluno e entre com um plano de ação, para que haja um aproveitamento melhor do que estão aprendendo.

\section{O ENSINO DA LÍNGUA PORTUGUESA}

O ensino da Língua Portuguesa nas escolas brasileiras tem, desde sempre, o objetivo de promover o conhecimento sobre a língua falada aos estudantes com o intuito de conhecerem mais sobre sua cultura e, consequentemente, a comunidade linguística da qual fazem parte. Tal objetivo pode ser encontrado em documentos nacionais sobre educação, tal como os Parâmetros Curriculares Nacionais (PCNs):

O domínio da linguagem, como atividade discursiva e cognitiva, e o domínio da língua, como sistema simbólico utilizado por uma comunidade lingüística, são condições de possibilidade de plena participação social. Pela linguagem os homem e as mulheres se 
comunicam, têm acesso à informação, expressam e defendem pontos de vista, partilham ou constroem visões de mundo, produzem cultura. (PCNs, 1998, p.19)

Ainda que os PCNs tenham sido repensados pela Base Nacional Comum Curricular (BNCC), os objetivos em relação ao ensino da Língua Portuguesa foram mantidos, embora com o avanço da tecnologia, a forma de se trabalhar determinados assuntos tenha sido alterada. A proposta é trabalhar o texto como unidade central e, a partir dele, fazer relações com contextos de produção. Para isso, devem-se mobilizar conhecimentos sobre os gêneros textuais previamente adquiridos, assim como sobre a língua e a norma-padrão, para que seja possível ampliar a participação em esferas de atividades humanas.

Ao componente Língua Portuguesa cabe, então, proporcionar aos estudantes experiências que contribuam para a ampliação dos letramentos, de forma a possibilitar a participação significativa e crítica nas diversas práticas sociais permeadas/constituídas pela oralidade, pela escrita e por outras linguagens. (BNCC, 2017, p. 6768)

Contudo, ainda que se tenha o objetivo de relacionar as teorias aprendidas na escola às práticas cotidianas, a maior parte das escolas mantém um ensino tradicionalista quanto à Língua Portuguesa, uma vez que os conhecimentos gramaticais são exaltados enquanto a variante linguística trazida pelo estudante (seja por contexto familiar, situação econômica ou de classe social) é excluída. Neste ponto é possível salientar que a forma como a Gramática Normativa é "cobrada" nas provas reflete como o método tradicional ainda encontra-se ligado às escolas, uma vez que tal sistema avaliativo exige a memorização de diversas regras gramaticais, as quais, muitas vezes, não são utilizadas no cotidiano do estudante e servem apenas para serem aplicadas no momento em que ele está sendo avaliado.

Outro fator que se torna complicador é a dissociação das três principais vertentes da Língua Portuguesa (Gramática, Literatura, Produção textual). Isso ocorre uma vez que a herança tradicionalista trata cada disciplina de forma fechada, fazendo com que a interdisciplinaridade seja um objetivo difícil de alcançar. Assim sendo, a Língua Portuguesa, por se tratar de uma disciplina com diferentes vertentes, trata também cada uma dessas de forma desvinculada das outras vertentes.

\section{A MUDANÇA DE VISÃO A PARTIR DA VIVÊNCIA NO ESTÁGIO}


O estágio supervisionado é uma vivência prática que aproxima e prepara o licenciando da realidade de sua área de formação, sendo assim permite uma integração e uma troca de experiências no âmbito escolar, além de ter a oportunidade de vivenciar toda a teoria adquirida na graduação. Os estágios são importantes, pois por meio dessa experiência é possível observar como se dá a relação entre docente e discente na sala de aula, utilizando como ponto inicial o meio em que o professor se encontra e a partir disso, fazer uma analogia, uma vez que é conhecedor da sua própria realidade e assim consegue aprofundar e transmitir os seus conhecimentos aos alunos.

Entender essa relação entre professor e aluno é primordial para que desta forma exista um relacionamento de trocas de ideias e conhecimentos, além de ser importante que o docente saiba lidar com as diferenças entre os alunos, visto que os estudantes não são apenas números e sim seres humanos em formação. O estágio proporciona ao futuro professor essa realidade da sala de aula e as possíveis dificuldades e obstáculos que irá enfrentar futuramente.

Por isso com a vivência no estágio é possível adquirir grandes benefícios para a aprendizagem, para o progresso de ensino que se refere a sua formação, levando em conta o fato de colocar em prática uma atitude reflexiva sobre a mudança de visão e inversão dos papéis de quando foi aluno e da sua vida futura como educador.

O estágio supervisionado torna-se fundamental no processo de formação docente, pois possibilita condições aos futuros educadores, em específico aos estudantes da graduação, uma relação próxima com o ambiente escolar que envolve o cotidiano de um professor e, a partir desta vivência os graduandos começarão a se compreender como futuros docentes, pela primeira vez encarando o desafio de conviver, falar e ouvir, com linguagens e saberes desse meio, propiciando uma aproximação à realidade na qual atuará.

\begin{abstract}
Conclui que o estágio, ao contrário do que se propugnava, não é atividade prática, mas teórica, instrumentalizadora da práxis docente, entendida esta como atividade de transformação da realidade. Nesse sentido, o estágio curricular é atividade teórica de conhecimento, fundamentação, diálogo e intervenção da realidade, esta, sim, objeto da práxis. Ou seja, é no contexto da sala de aula, da escola, do sistema de ensino e da sociedade que a práxis se dá. (PIMENTA, 1994.p.45)
\end{abstract}

O estagiário, durante sua permanência na escola em que realizará o estágio, tem acesso ao espaço escolar, sala de aula e tem a oportunidade de observar o método dos professores já atuantes e a relação entre os educadores e educandos na sala de aula. Essas observações e participações do licenciando oportunizam a esses futuros professores 
informações e vivências de como se dá na prática o processo de ensino aprendizagem.

Dessa forma, com a realização do estágio se estabelece uma experiência satisfatória, despertando outra visão aos futuros docentes, fato que contribuirá para a realização e efetivação de um trabalho com mais consciência e preparo, evitando possíveis situações extremas na realização de atividades em sala de aula. Esse contato estabelecido no período de estágio traz mais confiança ao estagiário e facilita o método de aprendizagem dos futuros alunos.

Assim, a prática docente deve ser refletida a cada atividade desenvolvida para que, dessa forma, seja possível progredir e por meio do estágio os licenciandos tenham o aprendizado efetivo e necessário para serem cidadãos atuantes e possam entender melhor o que enfrentarão futuramente atuando como professor. Consequentemente pode-se considerar que o estágio supervisionado proporciona uma experiência única e é neste momento que o graduando se vê como professor ou não, se identifica ou não com a sala de aula e todas as situações e desafios encontrados nela.

\section{RESULTADOS OBTIDOS A PARTIR DA PESQUISA REALIZADA}

Para a comprovação dos dados, foi realizado um questionário, o qual os estudantes de Letras, que já começaram suas experiências no estágio supervisionado, responderam a questões acerca das metodologias de ensino. No formulário, havia perguntas sobre qual o tipo de escola o indivíduo frequentou, como ele definiria o método de ensino utilizado e quais fatores o levaram a essa resposta. Além disso, foi questionado se as três principais vertentes (Gramática, Literatura e Produção Textual) eram vinculadas entre si ou apresentadas separadamente. Por fim, a última pergunta era voltada para a vivência que os estudantes do curso de Letras tiveram a partir de sua formação para docente e a partir do estágio supervisionado: a visão sobre o ensino da Língua Portuguesa mudou ou continuou a mesma? O questionário foi respondido por 15 pessoas com os seguintes resultados:

Gráfico 1 - Tipo de escola frequentada 


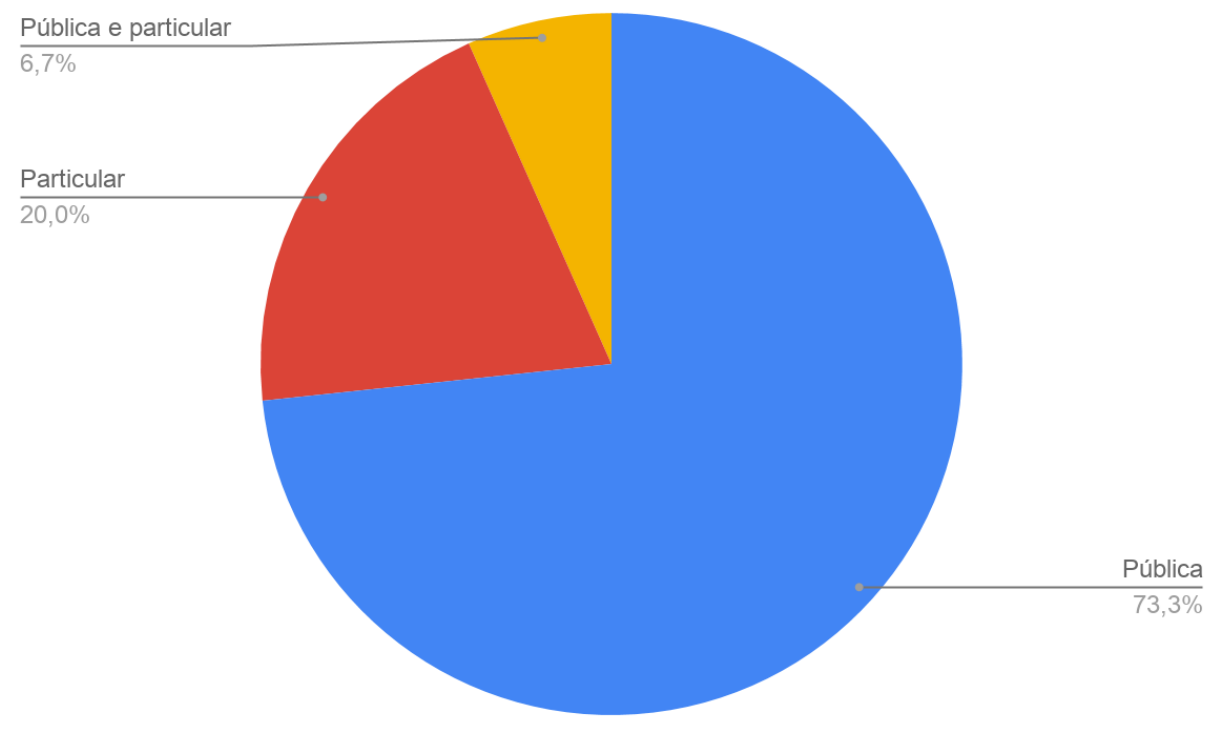

Fonte: dados da pesquisa

Gráfico 2 - Metodologia de ensino

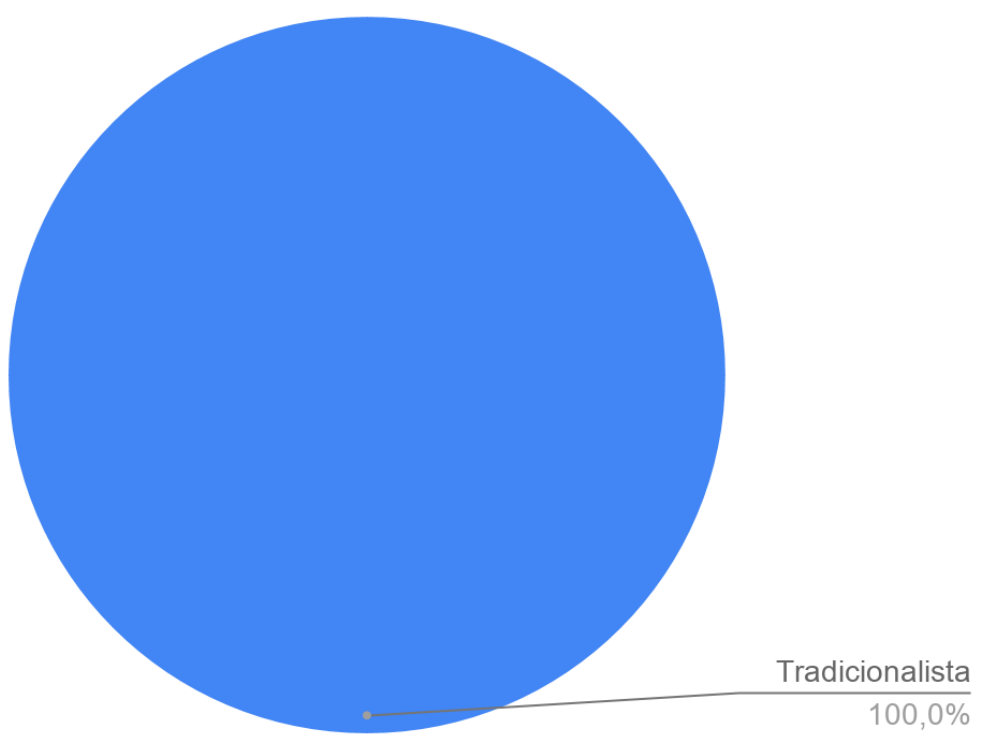

Fonte: dados da pesquisa 
Gráfico 3 - Como as 3 principais vertentes eram apresentadas

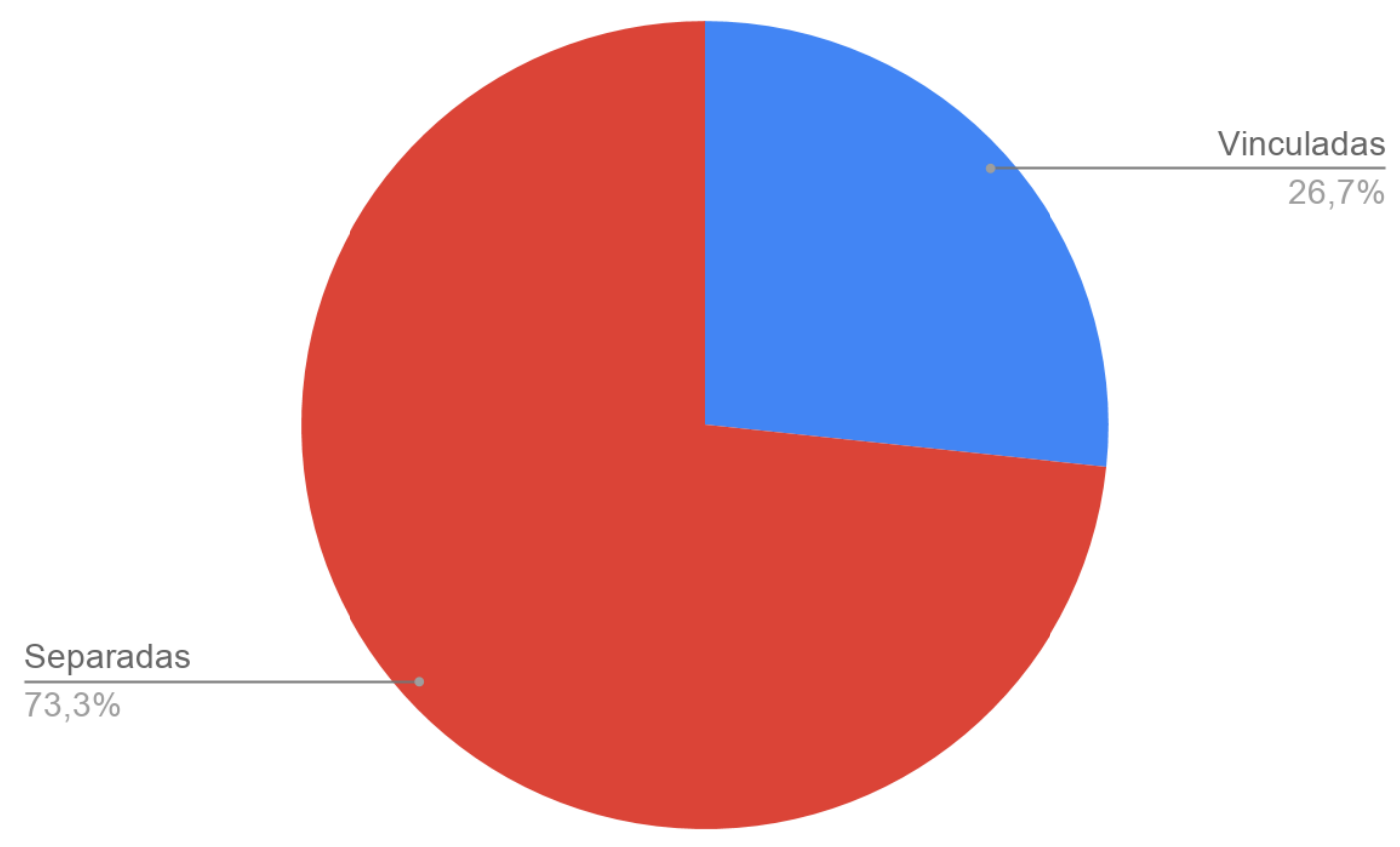

Fonte: dados da pesquisa

Gráfico 4 - A visão sobre o ensino da Língua Portuguesa

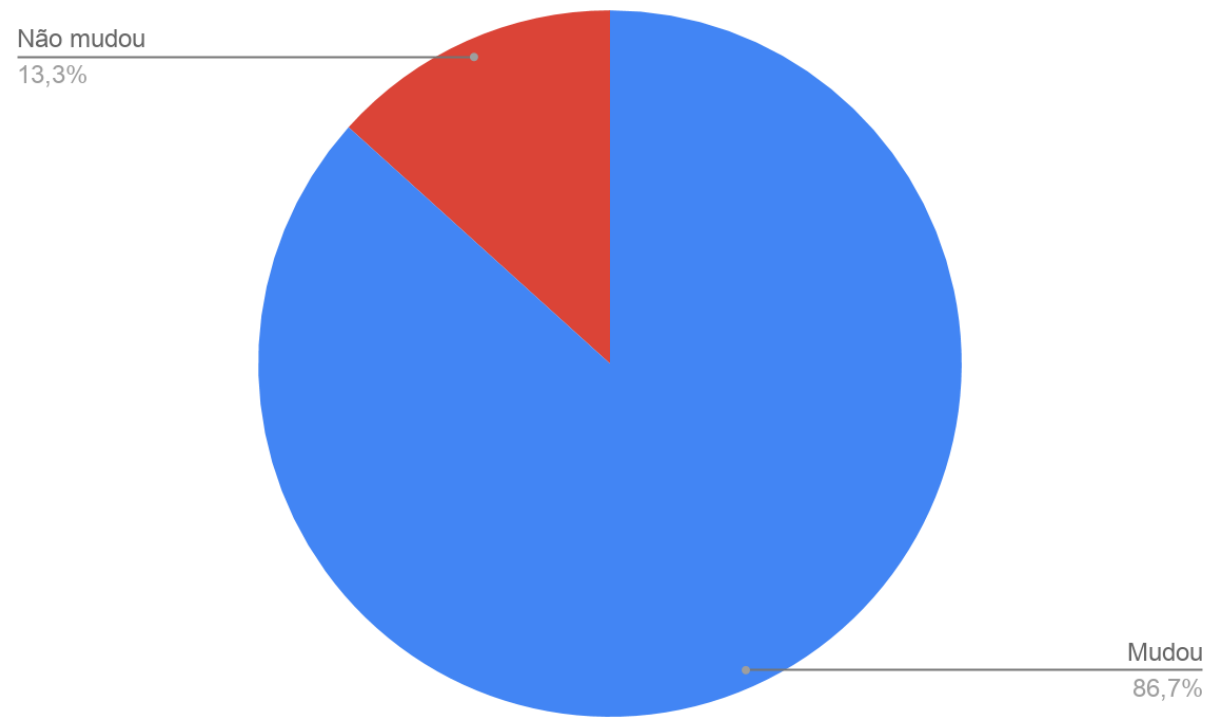

Fonte: dados da pesquisa 
Dessa forma, comprova-se que todos os informantes tiveram um ensino tradicionalista, no que diz respeito à Língua Portuguesa, uma vez que as três vertentes principais, já citadas neste trabalho, eram abordadas separadamente durante a trajetória escolar, na maioria das vezes. Em alguns casos a Gramática era priorizada, sem que houvesse uma relação entre teoria e prática cotidiana, enquanto a Literatura, por vezes, era pouco abordada durante as aulas.

De acordo com as informações coletadas na pesquisa, a maioria dos estudantes observou uma mudança de visão em relação ao ensino da Língua Portuguesa por meio da vivência no Estágio Supervisionado. Algumas observações feitas foram que, a partir de aulas do curso de Letras e experiências adquiridas durante o estágio, novas formas de ensinar foram aprendidas, além de se perceber a importância de se trabalhar as competências da Língua simultaneamente.

\section{CONSIDERAÇÕES FINAIS}

Portanto, ao permanecer no método tradicionalista, o ensino da Língua Portuguesa torna-se precário, haja visto que as vertentes da própria Língua são ensinadas de forma desvinculada, o que torna difícil uma interdisciplinaridade com as demais disciplinas do currículo escolar.

Adotando uma metodologia construtivista, o professor dá oportunidade para que o estudante possa construir seu próprio conhecimento, uma vez que o professor é um mediador e não apenas um transmissor de informações e, consequentemente, conhecimento. Além disso, é importante compreender que cada estudante tem suas próprias características de aprendizagem e uma forma única de aprender. Sendo assim, o professor, como mediador, deve estabelecer uma relação de troca de ideias, respeitar a individualidade de cada estudante e assim evitar interferências, pois cada educando possui seu ritmo de aprendizagem.

Em relação ao método de avaliação, na abordagem construtivista não há uma avaliação que meça o conhecimento adquirido pelo estudante no decorrer de um longo período, como é visto na abordagem tradicionalista, e sim um sistema avaliativo que acompanhe a evolução do estudante.

Conclui-se que as experiências vivenciadas durante o curso de Letras, tal como no decorrer do Estágio Supervisionado, tiveram grande importância para os licenciandos da turma de 2019, uma vez que tais vivências serão certamente lembradas e utilizadas no início da carreira docente de cada um. A busca por novas abordagens de ensino é uma tarefa necessária, uma 
vez que se pretende buscar cada vez mais uma melhora na educação do Brasil.

\section{REFERÊNCIAS}

BRASIL. Secretaria da Educação Básica. Disponível em: http://portal.mec.gov.br/seb/arquivos/pdf/portugues.pdf Acesso em: 05/09/2019)

CURY, A. Escola da Inteligência. In: : O que é o método de ensino construtivista?Disponível em: https://escoladainteligencia.com.br/o-que-e-ometodo-de-ensino-construtivista/ Acesso em: 15/07/2019

ELIAS, M. C. As Ideias construtivistas mudam os caminhos da prática da alfabetização. São Paulo: Revista da Ande, v.11, n.18, p.49-56, 1992.

MEC. Base Nacional Comum Curricular. Disponível em: http://portal.mec.gov.br/index.php?option=com_docman\&view=download\&alias=79 611-anexo-texto-bncc-aprovado-em-15-12-17-pdf\&category_slug=dezembro-2017pdf\&Itemid=30192. Acesso em: 29/06/2019.

MIZUKAMI, Maria da Graça Nicoletti. Ensino: as abordagens do processo. São Paulo: EPU, 1986. (Temas básicos da educação e ensino)

PIAGET, J. O Nascimento da inteligência na criança. 2. ed. Rio de Janeiro: Zahar; Brasília: INL, 1975.

PIMENTA, Selma Garrido; LIMA, Maria Socorro Lucena. Estágio e docência. São Paulo/BRA: Cortez, 2004. 


\title{
PRÁTICAS AVALIATIVAS NA DISCIPLINA DE HISTÓRIA DA EDUCAÇÃO: A percepção dos futuros professores
}

\author{
NASCIMENTO, Mari Clair Moro \\ Doutora em Educação - UEL \\ mariclairmoro@hotmail.com \\ VAGULA, Edilaine \\ Doutora em Educação - UEL \\ edilainevagula@yahoo.com \\ OLIVEIRA, Anelise Martinelli Borges \\ Doutora em Educação - UFTM \\ anelisemartinelli@hotmail.com
}

\section{INTRODUÇÃO}

A defesa da relevância da disciplina de História da Educação na formação docente decorre de leituras acerca da temática, mas também das próprias vivências, porque ao estudar sobre como se deu o desenrolar do processo educativo ao longo da história da humanidade, é possível conhecer a sua intencionalidade em cada contexto e pensar sobre as práticas pedagógicas a serem instituídas no momento atual. Diante disso, essa compreensão favoreceu a revisão das próprias ações, principalmente quando se é professor formador de outros professores, companheiros de profissão. Mas, é possível que surja o seguinte questionamento, "para que saber da intencionalidade da educação em cada contexto histórico? Cabe ressaltar que ao tratar de cada período da história este remete ao cenário econômico, político, social e cultural em que se encontra a sociedade, sendo importante tal olhar porque a educação formal, sob a responsabilidade da escola, portanto institucionalizada, ao estar inserida no contexto social sofre influências desses elementos que acabam interferindo na prática docente e assim, no perfil de sujeito a ser formado.

Frente ao exposto, este texto apresenta a importância da disciplina de História da Educação na formação docente, explanando ainda sobre como ela foi concretizada em uma turma de primeira série que cursa Pedagogia em uma universidade pública situada no norte do Estado do Paraná. Participaram do estudo trinta e quatro estudantes, futuros professores. O objetivo principal da pesquisa é revelar o que eles aprenderam ao cursarem a disciplina e vivenciarem a aplicação dos instrumentos avaliativos, ao longo do semestre. A atenção se volta para tais aspectos porque conforme anunciam Catani (1998) e Tardif (2002) as vivências na formação inicial poderão ter 
interferência nas práticas docentes desses futuros professores, quando estiverem no exercício da profissão, pois a constituição da identidade se dá ao longo da vida, ou seja, é um "[...] saber plural, formado de diversos saberes provenientes das instituições de formação, da formação profissional, dos currículos e da prática cotidiana." (TARDIF, 2002, p. 54).

O texto apresenta primeiramente como foi ministrada a disciplina de História da Educação no curso pesquisado. Na sequência, expõe o que dizem estudiosos do tema a respeito da referida disciplina na formação inicial para a docência e também sobre como deve ocorrer o processo da avaliação da aprendizagem. As respostas obtidas a partir de questionário, aplicado aos alunos, foram analisadas no entrelaçar do que expõem os teóricos de ambas as temáticas. Assim, o estudo foi realizado para conhecer o objeto "[...] através dos olhos daqueles que estão sendo pesquisados." (BRYMAN, 1988 apud BAUER; GASKELL, 2002, p. 32), tendo, portanto, embasamento na abordagem qualitativa para "[...] captar o universo das percepções, das emoções e das interpretações dos informantes." (TRIVIÑOS, 1987, p. 82). A coleta de dados foi obtida mediante o questionamento de duas perguntas aos estudantes de Pedagogia: 1) Quais aprendizagens você obteve na disciplina de História da educação? e 2) Dos instrumentos avaliativos vivenciados, qual possibilitou a você mais aprendizagens ? Por quê? Os estudantes participantes responderam às perguntas no último dia de aula da disciplina, quando já tinham vivenciado todo o processo de ensinar, aprender e avaliar. Suas respostas foram lidas atentamente, analisadas e categorizadas a partir do corpus teórico utilizado no estudo. Suas falas estão distribuídas ao longo do texto, acompanhadas pelas siglas $A 1, A 2, A 3 \ldots A 34$.

\section{A ESTRUTUAÇÃO DA DISCIPLINA DE HISTÓRIA DA EDUCAÇÃO}

A disciplina, intitulada por História da Educação e a Produção da Escola Moderna, em que se deu a pesquisa, efetivou-se no ano de 2019, na universidade pesquisada no primeiro semestre da primeira série do curso de Pedagogia, com a carga horária de 72 horas semestrais, cumpridas em encontros de quatro horas, uma vez por semana. Além dessa carga horária, a disciplina contempla também 18 horas para o cumprimento da Prática como Componente Curricular - PCC, conforme prevê a Resolução 02/2002 que "Institui a duração e a carga horária dos cursos de licenciatura, de graduação plena, de formação de professores da Educação Básica em nível superior". (CONSELHO NACIONAL DE EDUCAÇÃO, 2002, p. 1).

No seu programa (UNIVERSIDADE, 2018a) consta a ementa, os objetivos a serem alcançados, o conteúdo programático, a metodologia, os procedimentos de ensino e recursos, a avaliação da aprendizagem, bem como 
a bibliografia básica utilizada nas aulas e a complementar, indicada aos alunos. $\mathrm{Na}$ ementa consta que abordagem do conteúdo se centra em compreender "O processo histórico de sistematização da educação e da escola no ocidente, do século XV ao XIX, com ênfase no processo de institucionalização da educação. Reorganização da sociedade, escola e Direitos Humanos." (UNIVERSIDADE, 2018b, p. 17).

Acerca dos objetivos da disciplina, o programa indica que ela visa

1 - Analisar as características da história como área de conhecimento e sua importância para a compreensão do fenômeno educativo, bem como identificar a função e o lugar assumidos pela História da Educação na formação do pedagogo.

2 - Analisar o processo de constituição e organização das instituições escolares no ocidente dos séculos XV ao XIX. (UNIVERSIDADE, 2018a, p.1).

Sobre o conteúdo programático, abrange a relevância da História da Educação na formação docente, bem como os antecedentes históricos da educação moderna, portanto, a escolarização na Idade Antiga e Medieval, quando se voltam os olhares para as transformações econômicas, produtivas e culturais que interferem na transmissão da cultura letrada. Trabalha-se ainda 0 início da escola moderna - séculos XV ao XIX.

No que se refere à metodologia, aos procedimentos de ensino e recursos utilizados, por ficar explícita a relevância de os futuros professores entenderem a constituição do processo educativo, em cada contexto e a partir de diversas estratégias e recursos a serem utilizados em sala de aula, as atividades contemplaram a leitura de textos, reflexões individuais e em grupo, explicações pela professora, sínteses e resumos sobre os textos lidos, realizados pelos estudantes. As atividades propostas foram sempre acompanhadas pela docente responsável por ministrar os conteúdos, tendo em vista, ao longo do processo perceber as dúvidas e incompreensões a serem sanadas.

Em se tratando da avaliação da aprendizagem a ementa evidencia que:

\begin{abstract}
A avaliação do trabalho discente e docente deve ser permanente, permitindo re-orientações dos textos e dos procedimentos. Com a finalidade de avaliar o desempenho acadêmico dos estudantes, utilizaremos trabalhos individuais ou em grupo desenvolvidos extraclasse, apresentações orais em sala e provas escritas conforme acordo com a turma. Os critérios para avaliação dessas atividades serão: compreensão da proposta da tarefa, domínio do conteúdo, pertinência dos argumentos, clareza e correção de linguagem. (UNIVERSIDADE, 2018a, p. 2).
\end{abstract}

Frente ao indicado na ementa da disciplina, além das atividades realizadas ao longo do processo, para saber se e como os estudantes estavam 
compreendendo o conteúdo, houve também momentos para aplicação de instrumentos a consolidarem a avaliação na modalidade somativa, porque é preciso atribuir uma nota ao final de um determinado período, neste caso a cada bimestre. Para isso, ao final do primeiro bimestre os alunos responderam questões dissertativas em uma prova escrita. Após análise, correção e atribuição das notas pela professora às questões respondidas pelos estudantes, houve devolutiva à turma sobre o rendimento que demonstraram neste instrumento avaliativo, momento em que cada aluno foi individualmente posicionado sobre suas incompreensões, tendo no exato momento uma nova explicação pela professora. Nesta perspectiva, a nota de cada aluno acabou por revelar as incompreensões ainda existentes, sendo possível a retomada naquele instante e ao longo das próximas aulas, de um jeito diferente, porque se não houve entendimento pelo aluno com uma forma de explicar pelo professor, cabe-Ihe variar as estratégias de ensino. Assim, o processo avaliativo possibilitou também ao professor perceber a necessidade de ensinar de um jeito diverso, sendo concretizada a avaliação na concepção formativa, porque veio a favorecer melhorias no ensino e na aprendizagem. Para a nota do segundo bimestre, que encerraria a disciplina, já que possui carga horária semestral, os alunos foram consultados pela professora sobre como gostariam de revelar o que aprenderam. A proposta era que não fosse realizada novamente a prova, mas que pudessem se utilizar da criatividade para demonstrar as aprendizagens alcançadas. Após alguns momentos de reflexão entre eles, decidiram que seria em grupo, ficando para cada um a escolha da forma como apresentariam o conteúdo estudado. Ficou combinado também que no transcorrer das próximas três semanas que faltavam para 0 encerramento da disciplina seria reservado um período das aulas para os grupos se organizarem e montarem suas apresentações, e assim aconteceu. Além disso, sugeriram que as apresentações contemplassem todos os textos trabalhados, porque assim poderiam retomar os conteúdos. Assim, no momento das apresentações os grupos revelaram suas aprendizagens por meio de: paródia, vídeos por eles elaborados, momento em que atuaram como protagonistas, tanto na elaboração como na participação, mapa conceitual e talk show5. Ao longo das apresentações a professora foi posicionando a turma sobre as incompreensões ainda existentes, reveladas em suas falas, visto que não teria tempo posteriormente, por se tratar da finalização da disciplina. Ao término de cada apresentação, foi concedido também feedback a cada grupo, sobre a abordagem realizada na apresentação, bem como pontos positivos e negativos. Neste momento os alunos se posicionaram sobre o processo

\footnotetext{
${ }^{5}$ Talk show refere-se a um gênero de programa de televisão em que os participantes, mediados por alguém, discutem sobre diversas temáticas.
} 
vivenciado, dizendo sobre o quanto aprenderam com a atividade realizada, neste instante eles se posicionaram que aprofundaram o conteúdo a ser apresentado, mas que na realização do trabalho em grupo é preciso se posicionar, ao mesmo tempo em que é preciso escutar os demais integrantes.

Em relação à bibliografia básica indicada e explorada, foram utilizados os textos apresentados no quadro 1. Eles estão na sequência em que foram trabalhados, porque foram explorados primeiramente aqueles que se referiam à História da Educação na formação docente e posteriormente os que tratavam do histórico do processo educativo:

Quadro 1 - Textos utilizados na disciplina

\begin{tabular}{|c|l|}
\hline № & \multicolumn{1}{|c|}{ Texto } \\
\hline 1 & $\begin{array}{l}\text { BORGES, Vavy Pacheco. História, hoje em dia. Em: BORGES, Vavy Pacheco. O } \\
\text { que é História. São Paulo: Brasiliense, 1983, p. 44-66 }\end{array}$ \\
\hline 2 & $\begin{array}{l}\text { RABELO, Islei Gonçalves; RODRIGUES, Rosangela Silveira. História da } \\
\text { educação e a formação docente: possibilidades e contribuições para uma prática } \\
\text { emancipadora. 2010. Disponível: encurtador.com.br/btT08. Acesso: 15 mar. 2019. }\end{array}$ \\
\hline 3 & $\begin{array}{l}\text { STEPHANOU, Maria; BASTOS; Maria Helena Camara (Orgs.). Histórias e } \\
\text { Memórias da Educação no Brasil. Vol. III - Século XX. 3. Ed. Petrópolis: Vozes, } \\
\text { 2009, p. 416-419. }\end{array}$ \\
\hline 5 & $\begin{array}{l}\text { HILSDORF, Maria Lucia Spedo. Dos Primórdios do Cristianismo ao final da Idade } \\
\text { Média. Em: HILSDORF, Maria Lucia Spedo. O aparecimento da escola moderna: } \\
\text { uma história ilustrada. Belo Horizonte: Autêntica, 2012, p. 9-53. }\end{array}$ \\
\hline 5 & $\begin{array}{l}\text { HILSDORF, Maria Lucia Spedo. A escola secundária erudita. Uma história } \\
\text { ilustrada. Em: HILSDORF, Maria Lucia Spedo. O aparecimento da escola } \\
\text { moderna: uma história ilustrada. Belo Horizonte: Autêntica, 2012, p. 56-107. }\end{array}$ \\
\hline 6 & $\begin{array}{l}\text { HILSDORF, Maria Lucia Spedo. A escola popular elementar. Em: HILSDORF, } \\
\text { Maria Lucia Spedo. O aparecimento da escola moderna: uma história ilustrada. } \\
\text { Belo Horizonte: Autêntica, 2012, p. 157-221. }\end{array}$ \\
\hline
\end{tabular}

Fonte: Ementa da disciplina (UNIVERSIDADE, 2018a)

Os textos foram indicados gradativamente, sendo solicitada a leitura prévia para que em sala de aula fossem realizadas as reflexões e a retirada de dúvidas dos alunos. Os textos complementares ficaram à disposição dos mesmos, para aprofundamento da temática em estudo.

Importante frisar que a organização da educação brasileira na atualidade foi também refletida no decorrer da disciplina, porque a história possibilita analisar as mudanças e permanências na atualidade, mas esse conteúdo será estudado por esses alunos no próximo semestre, na disciplina História da Educação Brasileira: séculos XVIII ao XIX.

\section{A HISTÓRIA DA EDUCAÇÃO NA FORMAÇÃO DOCENTE: O que dizem os teóricos e os futuros professores}

Atentar para como o processo educativo foi constituído ao longo da história da humanidade tem relevância porque o exercício profissional do 
professor se concretiza com práticas pedagógicas que foram construídas no decorrer do tempo, conforme perfil de sujeito a ser formado em cada período, sendo relevante que eles tenham essa compreensão. Nesta perspectiva, ao estudarem sobre essa temática na formação inicial para a docência os futuros professores conheceram como ela aconteceu na Antiguidade, na Idade Média e na Idade Moderna, conforme apontou A13:

Foi incrível passar por todos os períodos da história da educação, absorvendo tudo o que esses períodos nos trouxeram. Como foi na Grécia e em Roma, na Idade Média, fazendo uma linha do tempo até os dias atuais. É muito interessante ver através dessa matéria, como a educação se construiu e desconstruiu ao longo do tempo.

De acordo com Saviani (2008) saber como o processo educativo se deu ao longo dos tempos favorece repensar sobre a forma como precisa ser efetivado na contemporaneidade, pois é por meio da história

[...] que nós nos conhecemos e ascendemos à plena consciência do que somos; que pelo estudo do que fomos no passado descobrimos, ao mesmo tempo, o que somos no presente e o que podemos vir a ser no futuro, o conhecimento histórico emerge como uma necessidade vital de todo ser humano. (p. 151).

Aspecto também evidenciado pelos sujeitos participantes do estudo, porque consta em suas respostas que o conhecimento adquirido na disciplina oportunizou pensar em como atuar na atualidade.

A disciplina História da Educação me possibilitou a entender a construção da educação, quais aspectos positivos e negativos se deram nessa construção no decorrer dos anos, além de me proporcionar entender que em quanto docente, devo sempre levar em consideração as especificidades de cada geração a ser educada. (A12).

As crianças possuem necessidades diferentes conforme as gerações e não dá para educar uma criança de hoje com um método de 50 anos atrás, por exemplo, porque o mundo globalizado requer diversas possibilidades para ensinar, porque cada aluno aprende de um jeito. (A26).

[...] me fez compreender como a nossa educação foi sendo construída, sendo que períodos anteriores influenciam a forma que a educação é conduzida hoje. Sendo assim, depois de todo processo consegui notar que a educação que vivenciamos atualmente tem muita influência do passado. Portanto, o que ficou depois de um semestre foi a minha compreensão, o amadurecimento pela forma que vejo a história agora, e como isso é fundamental para que eu possa conduzir meus futuros alunos, porque depois de todo esse conhecimento enxergo a sociedade de uma forma crítica, notando que há história em tudo [...]. (A27).

A disciplina de História da Educação foi muito importante para mim, pois mudou meu ponto de vista sobre a história, porque não é somente conhecer o passado, ela mostrou que é preciso pensar em como fazer no presente. (A32). 
Essa disciplina, intitulada por História da Educação e a Produção da Escola Moderna, concretizada nesta instituição de ensino superior, ao perpassar pela educação na Idade Antiga e na Medieval, para compreensões sobre como tem início a escola na Modernidade, possibilitou aos alunos saberem das especificidades de cada contexto. Ao estudarem a educação na Idade Antiga, especialmente Grécia e Roma, os graduandos puderam compreender que ela não era concretizada da mesma forma para todos os sujeitos, havendo diferença na oferta aos homens considerados livres e aos escravos, especialmente na Grécia, pois conforme aponta Mariano (2012, p. 64):

\begin{abstract}
Apesar da democratização da sociedade, da estatização gradual do ensino, e da expansão do acesso às escolas - havia até alguns escravos (os pedagogos) que eram alfabetizados para acompanhar a educação de seus donos - a elite ainda tinha assegurado um direito maior à educação e à cultura, devido à sua influência política, o que não permitia muitas mudanças sociais.
\end{abstract}

Sobre a educação na Grécia, Saviani (2008, p. 149) afirma que "[...] a instituição escolar se desenvolverá na Grécia como paidéia, enquanto educação dos homens livres, em oposição à duléia, que implicava a educação dos escravos, fora da escola, no próprio processo de trabalho".

Essa diferença na disseminação do conhecimento também se deu em Roma, pois "As escolas destinavam-se principalmente aos homens das famílias mais ricas, que aprendiam poesia, geometria, música, retórica e filosofia. Às mulheres permitia-se, de certa forma, o estudo da música, a título de arte recreativa [...]" (MARIANO, 2012, p. 66). Fica, portanto, evidente que o acesso ao conhecimento diferenciava de acordo com os grupos sociais a que o sujeito pertencia, ou seja, entre homens livres e escravos, homens e mulheres etc.

Sobre a educação no período medieval, viu-se que os ensinamentos estavam atrelados ao cristianismo, sendo esclarecido que [...] na Idade Média as escolas trarão fortemente a marca da Igreja Católica." (SAVIANI, 2008, p. 149). De acordo com Mariano (2012, p. 66), "O poder político e o religioso misturavam-se de tal forma que os que maior acesso tinham à educação e, em especial, à escrita, eram os religiosos".

Neste período, a sabedoria divina seria a única fonte de conhecimento a ser propagada, porque levaria à salvação, motivo pelo qual as pessoas foram proibidas do acesso às obras clássicas, visto que elas não tinham o conteúdo do cristianismo. Assim, tem-se neste contexto uma cultura empobrecida, aquela que não oportuniza às pessoas tecerem questionamentos sobre a realidade em que se inserem. "Era importante que as pessoas 
continuassem desinformadas, alheias a novas ideias e incapazes de estruturar pensamentos mais elaborados, que pudessem modificar a sociedade." (MARIANO, 2012, p. 67).

No que se refere ao fato de haver modelos de educação diferenciados, para os grupos que compõem a sociedade, cita-se aquela destinada às mulheres, pois elas eram muito restritas ao conhecimento e "[...] vistas como seres imperfeitos e pecadores, e tinham um papel secundário na sociedade, visto que poderiam comprometer o poder econômico da Igreja se os religiosos com elas se envolvessem". (MARIANO, 2012, p. 67).

Sobre a educação na antiguidade, os futuros professores evidenciaram que:

Fazendo uma linha do tempo até os dias atuais, partindo da Grécia, de Roma e da Idade Média até os dias atuais, a gente percebe 0 dualismo escolar, pois a educação foi separada para meninos e meninas, existindo a exclusão de certas classes para o estudo. E ainda, existia também o controle do que as pessoas podiam ou não estudar, devido à forte presença da Igreja Católica no período medieval. Enfim, essa matéria trouxe muita bagagem e principalmente me fez entender que onde estamos inseridos atualmente foi nossa própria construção, pois, entendemos, ao longo do semestre, que os homens são responsáveis por transformar a sociedade onde vivem. A História da Educação nos emancipa a entender tudo o que passamos para chegar onde estamos. (A13).

Na disciplina de história da educação estudada no primeiro semestre eu aprendi que a Igreja Católica possuiu ligações com a educação, sendo permitido somente os meninos (em grande parte vindos da nobreza) frequentarem a escola, eles eram ensinados nos mosteiros onde seus professores eram os bispos, monges e padres. Outro assunto que aprendi nesse semestre foi sobre o surgimento das universidades através das corporações de ofício, que eram onde os artesãos se reuniam para falar e regulamentar as profissões e 0 processo artesanal que surgiu nas cidades. (A18).

Através dessa matéria pude aprender que antes as meninas eram proibidas de estudarem juntos com os meninos, elas recebiam uma educação informal, que era passada para elas através de suas mães, já os meninos recebiam uma educação mais formal, através dos mestres (bispos, monges, padres, etc. $\mathrm{Na}$ época medieval a responsável pela educação era a igreja, sendo ela a maior autoridade que havia naquele período. (A20).

Aprendi sobre como era o processo educacional na Antiguidade e na Idade Média, e como ele foi se desenvolvendo até surgirem as Universidades, que continuam se moldando até o dia de hoje. (A21).

Ao longo dos estudos pude aprender que o dualismo escolar esteve presente em todas as passagens históricas até o os tempos atuais. Ele se fez presente na Grécia e na Roma Antiga, na Idade Média e na Idade Moderna. Nesses períodos estudados pude perceber que a história possibilita compreender qual o papel, a finalidade e o modelo da educação de cada momento e como isto influenciou a sociedade. (A28). 
A percepção dos graduandos a respeito do dualismo na educação foi significativa, apontam também essa questão A5 e A9:

\begin{abstract}
Uma das coisas mais proveitosas no estudo da história da educação, é que tomamos consciência de que apesar de tantas mentes maravilhosas deixarem claro eexplícito que educação deve ser para todos, infelizmente não é bem isso que vemos. (A5).

Através dessa disciplina eu pude compreender como se deu o processo educativo, quais as mudanças que ocorreram durante esse processo e as diferentes formas de se educar. Algo que me impactou profundamente foi o dualismo escolar e como ele ainda se faz presente na atualidade de muitas escolas. (A9).
\end{abstract}

Ter consciência que ao longo da história da humanidade a educação se processou de forma diferente aos diversos grupos sociais, pode favorecer os futuros professores o repensarem sobre como atuarão quando estiverem no exercício da docência, para favorecer a todos a mesma oportunidade de acesso ao conhecimento. Frente ao exposto por A3, A9 e A16 pode-se inferir que a disciplina desencadeou-lhes uma atitude reflexiva.

\begin{abstract}
A disciplina me ensinou a olhar para a escola com uma visão mais crítica, pois não conhecia acerca do surgimento, ou do processo pelo qual a educação se transformou ao longo do tempo, com problemas como o dualismo escolar, e diversos outros que os professores brasileiros enfrentam até hoje (baixos salários, falta de reconhecimento profissional, etc). É preciso pensar sobre como agir quando eu for professora. (A3).
\end{abstract}

Como futura docente sei que essa matéria, que evidenciou a educação diferente para as pessoas, foi essencial para minha formação, porque transformou muitas concepções que não se encaixam mais atualmente. (A9).

Mas acho que de todas as aprendizagens que obtive a mais interessante foi conhecer o histórico das escolas, o porquê de cada estilo. Isso me fez pensar sobre os erros cometidos por professores nas escolas em que estudei, e a disciplina me fez entender o porquê dos comportamentos dos professores, e o quanto essas ações podem prejudicar um aluno. Com tudo isso penso em que professora ser. (A16).

Apareceu também em suas respostas reflexões que foram tecidas a respeito da memória, reconhecida como "[...] importante porque oportuniza rever práticas já vivenciadas, para saber se elas cabem ou não no contexto atual." (A7). Explanaram também essa mesma ideia A23, A25 e A33. Destacase tais apontamentos sobre a memória porque, segundo Stephanou e Bastos, (2009, p. 15) o relembrar possibilita "[...] exercitar nosso pensamento, nossas opções, tomadas de decisão sobre os agoras da educação de nosso tempo". Ou seja, ao buscarem na memória as vivências que tiveram nos bancos escolares, juntamente com os fundamentos teóricos obtidos ao longo da disciplina, os graduandos vão pouco a pouco percebendo as mudanças e 
permanências no processo educativo, o que pode favorecer a ressignificação de práticas vivenciadas, tendo atenção para as necessidades atuais.

Ficou evidente também nas respostas dos graduandos, outras contribuições que a disciplina História da Educação e a Produção da Escola Moderna oportunizou-Ihes:

Pude aprender sobre a grande importância que tem essa disciplina, pois a mesma traz elementos desde o início da educação podendo compreender porque algumas atitudes são diferentes hoje em sala de aula. (A2).

Consegui entender um pouco mais sobre a importância e dedicação exigida no trabalho do pedagogo, em qualquer fase da formação escolar, seja da criança pequena ou do ensino superior, esta profissão acaba sendo responsável direta ou indiretamente por socializar, ensinar e inspirar pessoas, transformando a humanidade. (A3).

Pude realizar reflexões sobre nossos métodos e sobre a nossas vivências, em síntese, posso dizer que aprendi a importância de observar as alterações na educação e analisar minhas próprias experiências para buscar ser sempre o melhor possível dentro da sala de aula, enquanto professora. (A4).

Aprendi a respeitar ainda mais os professores e todos os profissionais envolvidos com educação. E o melhor, deixou o gosto e o desejo de buscar ainda mais conhecimentos sobre essa temática. (A5).

Aprendi a importância de trabalhar em grupo (o que pra mim é uma dificuldade), interagir com outras opiniões, diferentes pessoas, porque isso ajudou muito no meu pessoal e no semestre, para que eu pudesse entender mais sobre o que é a Educação, como surgiu e qual sua missão, e com isso me ajudou a gostar mais do curso de pedagogia e me faz querer continuar nesse caminho, com o intuito de fazer alguma mudança na história da educação no futuro. (A11).

Me ajudou a saber da importância das ações dos professores para a construção de uma sociedade. (A14).

Pude entender como se deu sequencialmente o processo da história, essa disciplina me proporcionou o amplo entendimento da educação. (A30).

Percebi que a professora pensou no nível dos textos, com uma leitura simples e muito conteúdo. Isso me fez pensar que sempre temos que refletir para quem estamos ensinando, não adianta nada passar um texto super difícil que ninguém entende porque começar do básico para poder avançar é importante. Entendi também que o fracasso de muitos estudantes não é motivo de orgulho para o professor, essa frase a professora sempre repetia para nós, e me marcou muito. Pois no meu ensino médio eu tinha muitos professores que tinham orgulho de vários alunos ficarem de recuperação. A professora se mostrou muito experiente, compartilhando suas experiências, isso foi muito rico, acrescentou demais. Além disso aprendi a importância de uma professora dedicada, que se importa com os estudantes. (A34).

Eles revelaram que adquiriram saberes acerca da construção do processo histórico, objetivo principal da disciplina, mas indicaram também 
terem obtido conhecimentos sobre o exercício da docência e a atuação do pedagogo, além de A34 deixar claro a atenção para as ações da professora da disciplina. Neste caso, fica evidente que a prática do professor formador, junto aos graduandos, pode interferir no perfil de profissional a ser formado, aspecto que chama os professores que atuam na formação inicial para a docência, para o repensar sobre sua própria atuação, já que as vivências no momento da formação inicial podem interferir na construção da identidade do futuro professor (CATANI, 1998; TARDIF, 2002).

\section{A PRÁtICA AVALIATIVA EFETIVADA NA DISCIPLINA DE HISTÓRIA DA EDUCAÇÃO: Aprendizagens decorrentes}

Nesta seção do texto a atenção se volta para o que expuseram os sujeitos pesquisados na pergunta "Dos instrumentos avaliativos vivenciados, qual possibilitou a você mais aprendizagens? Por quê?". Tal questionamento foi realizado tendo por pressuposto a relevância de os futuros professores vivenciarem diferentes instrumentos no processo avaliativo, de modo a terem essa prática quando estiverem no exercício da profissão docente. Além disso, eles estiveram na condição de protagonistas, porque puderam se posicionar e escolher, ao final da disciplina, a forma como gostariam de explanar o que aprenderam ao longo do semestre. Ação favorecida pela intencionalidade da professora responsável pela disciplina, aspecto essencial de se fazer presente nas ações docentes, visto que conforme indica Franco (2008, p. 129-133), "[...] o saber pedagógico é uma prática que exige do professor a consciência e a intencionalidade de buscar uma transformação do aluno, pois implica do exercício de uma prática reflexiva, comprometida, com sentido, com intencionalidade".

Portanto, no que se refere às aprendizagens que os graduandos obtiveram a partir da aplicação dos instrumentos avaliativos, eles apontaram a importância dos trabalhos em grupo, conforme consta abaixo:

Aprendi a trabalhar em grupo, descobri que alguns colegas são mais empenhados que os outros, mas que se colaboramos uns com os outros conseguiremos fazer com que esses alunos também se interessem a interagir e possam caminhar para a formação profissional e consequentemente para o sucesso pessoal. (A1).

$\mathrm{O}$ instrumento avaliativo que me proporcionou mais aprendizagem foram os grupos que eram formados, esses grupos proporcionaram debates que fazíamos uns com os outros sobre o conteúdo, aprendi a ter menos vergonha e principalmente o que ficou de mais importante em minha concepção foi em como a interação pode nos fazer aprender. (A27).

Os trabalhos de discussão em grupo. É nesse momento que conseguimos compartilhar ideias diferentes ou até mesmo iguais. Quando diferentes, a partir da conversa se torna possível a 
compreensão de coisas que não entendemos e assim uma formulação de um pensamento mais coerente. (A29).

Fica aparente em suas respostas, a percepção de que por meio da interação e do diálogo com o outro é possível ampliar os conhecimentos já existentes, pois

\begin{abstract}
O diálogo é o encontro entre os homens, intermediado pelo mundo, para nomear esse mundo. Se é por meio da palavra, ao nomear o mundo, que os homens o transformam, o diálogo se impõe como o caminho pelo qual os homens encontram o significado de serem homens. Logo, o diálogo se constitui como uma necessidade existencial [...] não pode se limitar ao fato de uma pessoa "depositar" ideias em outra, como também não pode se tornar uma simples troca de ideias, que "seriam consumidas" por aqueles que estão conversando. Também não consiste numa discussão hostil [...] na imposição da própria verdade. (FREIRE, 2016, p. 135-136).
\end{abstract}

Além de considerarem as reflexões realizadas no coletivo, como favorecedoras à aprendizagem, apareceu também em suas respostas a aplicação da prova, respondida individualmente.

Eu gostei da primeira avaliação, pois me possibilitou ir mais a fundo nas partes que realmente importavam, e não ficar decorando detalhes desnecessários. (A6).

Dos instrumentos avaliativos vivenciados, o que me possibilitou mais aprendizagens foi a primeira prova escrita do primeiro bimestre. Acredito que a partir do momento que precisei ler e absorver tudo o que os textos me ofereciam, fazendo resumos, mapas conceituais, leituras, buscando além do que os textos me ofereciam, eu pude ter uma absorção maior da matéria. (A13).

Achei que todos os instrumentos avaliativos usados conseguiram cumprir seu papel de mostrar o aprendizado de cada aluno, gosto muito da prova tradicional que foi a primeira forma de avaliação que usou, não sei se foi porque compreendi o conteúdo mas achei ela tranquila e confortável de fazer pois os conteúdos e as questões estavam claras. (A16).

A prova discursiva, para mim estudar para a prova e principalmente depois ter uma devolutiva dela, pela professora, é o que esclarece da melhor forma o conteúdo. Creio que desta forma consigo expressar melhor o que eu aprendi. (A32).

Eu gostei de realizar a prova escrita, pois eu gosto muito de realizar resumos para estudar. Todavia não acho que apenas a prova é o melhor meio para avaliar, pois muitas pessoas ficam nervosas e não conseguem se expressar. (A34).

Ao se referirem à prova, os graduandos trouxeram questões pertinentes de serem refletidas. O primeiro aspecto se refere à absorção do conteúdo (A6; A13), pois avaliar vai muito além de saber se o aluno memorizou o que foi ensinado, porque implica em mapear o que foi ou não por ele compreendido, porque o que ainda não foi entendido precisa ser retomado pelo professor de uma outra forma, superando assim a concepção classificatória da avaliação da aprendizagem. Outra questão se refere à devolutiva dada pela 
professora (A16), porque superar a avaliação na concepção classificatória demanda que o docente interprete junto ao aluno a nota atribuída, de modo que ele tenha clareza do que ainda lhe falta compreender. Nesta perspectiva, tem-se a efetivação do processo avaliativo na concepção formativa, a indicar ao aluno o que ainda é preciso alcançar na sua aprendizagem, tendo responsabilidade também o professor, porque cabe-lhe empreender outras formas de ensino a favorecerem a superação das incompreensões do aluno, porque avaliação na concepção formativa implica em

\begin{abstract}
[...] conhecer a qualidade dos processos e dos resultados. E, em educação, queremos conhecer para valorizar os processos que produzem certos resultados e intervir a tempo, se necessário, com a sincera intenção de assegurar o êxito dos que participam do mesmo processo educativo - decisão que brota da própria atividade avaliadora. Este deverá ser o sentido da avaliação formativa, que também será necessariamente contínua e pessoal. (ÁLVAREZ MÉNDEZ, 2002, p. 64).
\end{abstract}

E ainda, o apontado por A34, quando relata que a prova pode não ser o melhor instrumento para avaliar, já que pelo nervosismo existem pessoas que não conseguem ser expressar. Motivo pelo qual a disciplina se consolidou a partir da diversificação dos instrumentos avaliativos, tendo em vista coletar de diferentes formas informações sobre se e como os alunos estavam compreendendo o conteúdo ministrado, para, a partir dos resultados, professor e aluno terem ações a superarem as dificuldades ainda existentes.

A prática avaliativa que se fez presente em $100 \%$ das respostas se refere "A última avaliação que foi muito interessante, pois ficamos livres e a criatividade foi encantadora." (A34). Foi o momento em que eles estiveram espaço para, de forma criativa, apresentarem suas aprendizagens. Sobre essa atividade avaliativa, segue algumas de suas respostas:

Gostei muito da última forma de avaliação, na qual a professora nos deixou usar a criatividade para explicar o que entendemos da matéria ao longo do curso. Isso me ajudou muito a fixar a matéria, fugindo da forma de avaliação costumeira. (A2).

Todos os instrumentos avaliativos me possibilitaram aprender, mas o que eu mais gostei foi da nossa última atividade avaliativa, onde criamos algo criativo sobre o conteúdo a ser avaliado. Meu grupo fez um vídeo e apesar das dificuldades em filmar e gravar áudios, foi um trabalho em que me dediquei bastante, retomei todo o conteúdo e tive que fazer resumos para explicar nos áudios, ou seja, tive que voltar várias vezes o conteúdo para escrever as falas e ver o mais importante a ser dito. Foi um trabalho inovador, desafiador e muito produtivo. (A11).

Mas, a ação criativa como instrumento de avaliação foi algo incrível, principalmente para meu grupo, pois tínhamos um limite para o tempo do vídeo e tínhamos como proposta colocar todos os conteúdos trabalhados em sala, dessa forma tivemos que resumir muita coisa e para isso, tivemos que compreender e "dominar" ainda mais os 
conteúdos. Com isso, possibilitou a aprendizagem de forma mais tranquila. (A16).

Sem dúvidas, com o último trabalho. Porque fez com que eu fosse atrás do conteúdo com mais profundidade para que, na hora da apresentação, eu pudesse resumir de forma que se possa entender 0 conteúdo.( A26).

Dentre todas as avaliações, a última foi a que mais me possibilitou aprendizagens, pois tivemos que trabalhar em grupo, construir uma apresentação criativa e isso proporcionou um aprofundamento dos conteúdos de uma maneira mais leve. (A28).

Quando o aluno pode ser protagonista na sala de aula, ele se envolve muito e consegue, de uma maneira aprofundada, apresentar suas aprendizagens e superar limites, como evidenciou A25, "[...] eu sou tímido e puder treinar minha oratória". Sobre essa mesma atividade A7 respondeu que:

[...] ver a apresentação dos colegas fez com que o conteúdo ficasse ainda mais reforçado, e sobretudo, foi um exercício muito divertido, que também nos provocou a irmos além do cômodo e dos caminhos mentais habituais para estabelecermos uma relação mais verdadeira com a matéria tornando, a sala de aula o nosso local de representatividade.

Suas respostas revelaram que a atividade não foi fácil, porque demandou pensar em como organizá-la, já que deveria ser de forma criativa, e exigiu, ainda, muito estudo, porque "[...] um equívoco poderia gerar uma grande confusão, independentemente de a matéria ter seguido uma ordem histórica, então se misturássemos os períodos, não iria ter uma coerência na apresentação. (A20). Nota-se, portanto, que 0 envolvimento e 0 comprometimento, com a atividade e o conteúdo que deveria ser demonstrado pelo grupo à turma, se fizeram presentes, favorecendo não só a apropriação de saberes referentes à disciplina, mas também ao desenvolvimento pessoal dos futuros professores.

Nas respostas de alguns dos graduandos, outros apontamentos foram realizados, quando responderam sobre os instrumentos avaliativos:

Pude aprender muito sobre avaliar cada aluno de acordo com seu perfil, levando em conta sua herança cultural, classe social e vivências com familiares e amigos e jamais tentar compará-los na hora de avaliá-los, os igualar seria o mesmo que ignorar todas as circunstâncias citadas acima. (A1).

Gostei muito das aulas que possibilitaram maior integração professor/alunos, conciliando os textos com discussões e exemplos objetivos e práticos. (A3).

Gostei muito de suas aulas num geral. Muito obrigada, por esse semestre, por tanto aprendizado, com certeza levarei influências suas na minha carreira como pedagoga. (A11).

Para mim, o que mais me possibilitou aprender, foram os exemplos utilizados pela professora. A professora sempre dava um exemplo de 
todos os conteúdos da matéria, e isso fazia com que aprendesse mais, e conseguisse realizar as atividades. (A23).

Consta em suas respostas que a vivência na disciplina despertou a atenção às especificidades dos sujeitos (A1), que os exemplos citados pela professora regente favoreceu suas compreensões (A3; A23) e que a forma como a professora atuou influenciará nas ações de futuros professores (A11), quando do exercício da profissão, o que nos leva a retomar os apontamentos de Catani (1998) e Tardif (2002), ao enfatizarem que as práticas vivenciadas na formação inicial poderão influenciar a identidade dos futuros professores, quando estiverem no cotidiano da escola.

\section{CONSIDERAÇÕES FINAIS}

A análise cuidadosa das repostas dos alunos do primeiro ano do curso de Pedagogia, que cursaram a disciplina História da Educação e a Produção da Escola Moderna, possibilitou saber que no momento da formação inicial eles constroem conhecimentos teóricos, a partir da leitura e reflexões dos textos estudados, mas vão pouco a pouco, construindo uma concepção prática, acerca da consolidação do processo educativo, a partir das ações dos professores formadores.

No que se refere às aprendizagens obtidas na disciplina de História da Educação, eles revelaram o reconhecimento da sua relevância, ao proporcionar saberes referentes à estruturação do processo educativo em cada contexto, aspecto que oportuniza entender como a educação precisa se consolidar na contemporaneidade.

Sobre qual dos instrumentos avaliativos vivenciados proporcionou mais aprendizagens, consta em suas respostas que na maneira como foram aplicados e utilizados, todos eles favoreceram aprender, ficando em destaque aquele em que puderam atuar como protagonistas, visto que escolheram como apresentar seus conhecimentos. Ressalta-se, portanto, que a prática avaliativa concretizada na referida disciplina distanciou-se da concepção classificatória, apresentando características formativas, porque foram diversificados os instrumentos de coleta, para saber se e como os alunos estavam aprendendo, houve interpretação da nota da prova junto a cada graduando, sendo dada devolutiva do conteúdo incompreendido e efetivada a partir da estreita relação entre 0 atores do processo educativo, estudante e professor, mais uma característica da avaliação formativa. Consolidou-se então um modelo educativo que proporcionou voz e vez aos alunos.

Nesta forma de ser concretizada, a disciplina de História da Educação, ainda que reconhecida por muitas pessoas como totalmente teórica na formação inicial para a docência, favoreceu aos futuros professores uma 
ação prático-reflexiva, porque possibilitou-Ihes pensar sobre como atuar para a superação do dualismo escolar, que se consolida na oferta da educação diferenciada aos diferentes grupos sociais. Frente ao exposto, a referida disciplina tem seu mérito, por favorecer a formação do professor que faz uma leitura de mudo e busca atuar para promover a aprendizagem e o desenvolvimento de todos os sujeitos, independente da classe social em que se inserem.

\section{REFERÊNCIAS}

ÁLVAREZ MÉNDEZ, Juan Manuel. Avaliar para conhecer, examinar para excluir. Porto Alegre: Artmed, 2002.

BAUER, Martin W. Análise de conteúdo clássica: uma revisão. In: BAUER, Martin W; GASKELL, George. Pesquisa qualitativa com texto, imagem e som: um manual prático. Petrópolis: Vozes, 2002, p. 189-217.

CATANI, Denice Barbara. Prática de formação e ofício docente. Em: BUENO, Belmira Oliveira; CATANI, Denice Barbara; SOUSA, Cynthia Pereira de. A vida e o ofício dos professores. São Paulo: Escrituras, 1998, p. 23-30.

CONSELHO NACIONAL DE EDUCAÇÃO. Resolução CNE/CP 2, de 19 de fevereiro de 2002. 2002. Disponível em:

http://portal.mec.gov.br/cne/arquivos/pdf/CP022002.pdf. Acesso em: 17 ago. 2019.

FRANCO, Maria Amélia do Rosário Santoro. Pedagogia como ciência da educação. 2.ed. São Paulo: Cortez, 2008.

FREIRE, Paulo. Conscientização. Tradução de Tiago José Risi Leme. -São Paulo: Cortez, 2016.

MARIANO, Regina Pereira Curado. A educação da antiguidade aos nossos dias - em busca de indícios da origem das avaliações. Revista Tempos e Espaços em Educação, cidade, v.5, no 9, p. 61-76, 2012. Disponível: https://seer.ufs.br/index.php/revtee/article/view/2267/1938. Acesso: 27 ago. 2019.

SAVIANI, Dermeval. História da História da Educação no Brasil: um balanço prévio e necessário, EccoS - Revista Científica, São Paulo, v. 10, no especial, p. 147-167, 2008. Disponível:

http://www.redalyc.org/pdf/715/71509907.pdf. Acesso: 19 ago. 2019.

STEPHANOU, Maria; BASTOS, Maria Helena (Org.). História e memórias da educação no Brasil, vol. III: século XX. 3. ed. Rio de Janeiro: Vozes, 2009. 
TARDIF, Maurice. Saberes docentes e formação profissional. Petrópolis:

Vozes, 2002.

TRIVIÑOS, Augusto Nibaldo Silva. Introdução à pesquisa em ciências sociais. São Paulo: Atlas, 1987.

UNIVERSIDADE. Programa da disciplina. 2018 a.

. Resolução CEPE/CA № 118/2018. 2018b. Disponível em:

http://www.uel.br/prograd/documentos/resolucoes/2018/resolucao 118 18.pdf. Acesso em: 17 ago. 2019. 


\title{
PRÁTICAS E METODOLOGIAS NA FORMAÇÃO ACADÊMICA COM ALUNOS DO CURSO DE PEDAGOGIA: Uma possibilidade na formação docente
}

\author{
PERENTELLI, Léia Fernandes \\ Mestre em Educação - UFSCar \\ Docente - Faculdade Anhanguera \\ CAROTA, Filipe Pimenta \\ Mestre - UNESP \\ Docente - Faculdade Anhanguera
}

\section{INTRODUÇÃO E PERCURSO METODOLÓGICO}

A metodologia para o desenvolvimento da pesquisa se divide em dois momentos. Inicialmente, utiliza-se uma abordagem qualitativa evidenciando a identificação e compreensão das possibilidades didático pedagógicas quanto as práticas realizadas na universidade pesquisada. Em seguida, utiliza um estudo de caso com vistas a verificar até que ponto esta prática contribui para a aprendizagem significativa na perspectiva de uma formação profissional com qualidade.

Inicialmente, Menga e André (1986) definem que a pesquisa qualitativa se relaciona ao contato direto do pesquisador e do ambiente investigado durante a pesquisa. Dessa forma, o pesquisador busca ter uma maior vivência com o campo de trabalho, em um contato direto com o objeto da pesquisa. Nesse sentido, o presente trabalho é realizado pela coordenadora de curso da instituição abordada e por um dos professores que integram o corpo docente do mesmo curso. Ou seja, há uma relação dos pesquisadores com o campo de atuação. Essa mesma referência pontua que na pesquisa qualitativa, destaca-se a abordagem pelo estudo de caso. Outras considerações quanto ao uso da pesquisa qualitativa podem ser encontradas no texto de Hartmut Gunther (2006) no qual uma descrição e diferenciação é realizada tendo em perspectiva a pesquisa qualitativa e quantitativa. Na obra de Neves (1996) pontua-se que a pesquisa qualitativa tem como referência três abordagens: a pesquisa documental, estudo de caso e etnografia. A primeira com exame dos materiais que ainda não receberam um tratamento analítico. A segunda com uma análise profunda de uma unidade de estudo. A terceira envolve procedimentos interpretativos. Em uma definição quanto a opção pelo estudo de caso, destaca-se que:

O estudo de caso é o estudo de um caso, seja ele simples e específico, como o de uma professora competente de uma escola pública, ou complexo e abstrato, como o das classes de alfabetização (CA) ou do ensino noturno. O caso é sempre bem delimitado, 
devendo ter seus contornos claramente definidos no desenrolar do estudo. O caso pode ser similar a outros, mas é ao mesmo tempo distinto, pois tem interesse próprio, singular. (MENGA; ANDRÉ, 1986, p.17)

Como objeto de estudo, esse trabalho analisa as práticas pedagógicas e metodologias que são utilizadas no curso de Pedagogia na Anhanguera em Sertãozinho. Por meio desse estudo, busca-se a compreensão quanto a formação acadêmica dos alunos e suas contribuições na formação docente enquanto profissionais da área da educação. Para melhor compreender a instituição, podemos realizar a análise documental, na qual:

Os documentos constituem também uma fonte poderosa de onde se podem ser retiradas evidências que fundamental afirmações e declarações do pesquisador. Representam ainda uma fonte "natural" de informação. Não são apenas uma fonte de informação contextualizada, mas surgem num determinado contexto e fornecem informações sobre esse mesmo contexto. (...) Outra vantagem dos documentos é que eles são uma fonte não relativa" (MENGA, ANDRÉ, 1986, p. 39)

\section{A FORMAÇÃO ACADÊMICA: UMA ANÁLISE BIBLIOGRÁFICA}

A referência bibliográfica que fundamentou a pesquisa tem origem no manual elaborado por Barrenechea (2016) para a disciplina de "Redação Científica com uso de ferramentas tecnológicas" da UFPR e o texto de Osvaldo Oliveira Junior (2015) publicado pelo Instituto de Física da USP - São Carlos. Outros trabalhos com essa temática foram produzidos por Stockmanns; Perreira (2013, Cuenca; De Paula; França Junior (2017) e Soares; Severino (2018) e serviram como referência para desenvolvimento dessa pesquisa.

Inicialmente, a formação universitária tem o objetivo em formar novos pesquisadores, que aturaram na produção cientifica, conhecimento e difusão do saber. O espaço de atuação de novos profissionais vai desde o ambiente universitário, onde é possível manter um forte vínculo com 0 conhecimento acadêmico, quanto ao ambiente profissional. Nesse último, o saber é aplicado de forma prática, mas não obstante, de uma pesquisa de inovações e produção de novo saber que recriam a prática profissional. Seja no mundo acadêmico ou do trabalho, inovar e produzir conhecimento são parte fundante na vida de alguém que termina seu curso universitário.

Barrenechea (2016) ao desenvolver um manual com orientações para a disciplina de "Redação Científica com uso de ferramentas tecnológicas" da UFPR apontou que um texto pode não despertar interesse no primeiro contato entre o estudante e a leitura. Porém, após uma análise mais cuidadosa é possível que se apresentem interesses instantâneos ou evidentes de um 
assunto específico. É possível, por exemplo, a compreensão de um sentido ou despertar um sentido até então oculto para um leitor, até então despercebido.

Nesse texto, para orientar a leitura, são indicados alguns procedimentos para a compreensão do texto. O primeiro deles é a apresentação de estratégias de leitura. Em seguida, são apresentadas formas de leitura e produção de sentidos, buscando as concepções sobre o texto, a leitura e o leitor. No terceiro momento são indicadas as produções de texto acadêmicos e científicos. Nesse assunto o leitor toma conhecimento sobre características da redação científica, sobre o trabalho cientifico, citações e aspectos de normas técnicas, como a ABNT. Por fim, são apresentadas ferramentas tecnológicas para a pesquisa de textos científicos.

É comum na formação universitária o contato com a produção acadêmica. Por isso, habilitar os alunos em práticas pedagógicas que estimulam a leitura desses textos é uma vida de mão dupla: primeiro para o aluno, em seguida para a universidade. Alunos que desenvolvem a habilidade de leitura e compreensão do texto acadêmico possuem melhor desempenho ao longo da sua formação e dão sequência nos estudos em níveis de pósgraduação. Por outro lado, a universidade se torna uma referência na formação de profissionais pesquisadores e de produção de desenvolvimento em pesquisas cientificas, seja em nível local ou maior.

Outros trabalhos com essa temática foram produzidos por Stockmanns; Perreira (2013). Nesse relato de experiência, o trabalho tem o objetivo de aprofundar sobre a escrita acadêmica no nível superior. Analisando os alunos do IFPR - Campus de Palma, a composição científica do trabalho se baseou em aspectos dos conhecimentos básicos como as normas técnicas, da ABNT, a elaboração e a estruturação do pensamento científico na produção de conhecimentos, uma vez que:

\begin{abstract}
Proporcionar a escrita e reescrita de um texto é conhecer o sujeito que a produz, suas ideias, suas crenças, seus valores, seu contexto histórico-cultural e de que forma manifesta seu pensamento. Com isso, 0 ato de escrever passa por mudanças estruturais constantes, pois a língua não é estática e nem homogênea, é heterogênea, evoluindo ao longo do tempo como resultado da maneira como os falantes a utilizam, já que a língua vive pelo fato de existirem sujeitos que também constroem e desconstroem seus elementos linguísticos (escrita, oralidade e interação discursiva). (Stockmanns; Perreira, 2013, p.21392).
\end{abstract}

A sequência do estudo citado acima aponta ainda a importância não só do ato de ler, mas como também de escrever. Esse é um dos objetivos aplicados no curso de Pedagogia da Anhanguera após a leitura das obras. 0 texto aponta que escrever é um processo diverso, objetivo, e que constitui a formação do individual, tanto no aspecto cultural, social e cidadão. Por isso, é 
fundamental uma boa relação entre professor e aluno para que ler e escrever se tornem um hábito prazeroso. O oposto disso, é a ausência do significado naquilo que se produz em sala de aula ou fora do espaço escolar.

Stockmanns; Perreira (2013) pontuam também que o ensino superior requer do aluno vivências que exprimam a qualidade do ensino que é ofertado. Ao mesmo tempo que a leitura e escrita tem em si o lado social, na universidade, esses procedimentos estão ligados a formação profissional. Portanto, discutir, refletir e construir espaços para práticas pedagógicas e contato com a produção científica no meio universitário é uma necessidade na literatura, na construção do curso e na titulação profissional.

Cuenca; De Paula; França Junior (2017) apontam que outra estratégia utilizada para contato, produção e práticas pedagógicas no espaço universitário têm ocorrido na USP - universidade de São Paulo. A universidade realiza um projeto de Cultura e Extensão, em modalidade de difusão de $24 \mathrm{~h}$, no qual os docentes e pós-graduandos colocam seus resultados em artigos científicos. Um desse projetos, na análise realizada pelos autores, foi desenvolvido na área da saúde, no chamado Programa de Verão da Faculdade de Saúde Pública. Nesse curso houve o aprimoramento de bases teóricas e metodológicas para a escrita científica.

Por fim, o que a literatura acadêmica aponta quanto as práticas pedagógicas e a interação dos alunos com o meio científico podem ser localizadas na obra de Soares; Severino (2018) e servem como referência para desenvolvimento de pesquisas. Em uma análise do curso de pedagogia de uma determinada universidade, os autores elaboraram uma tabela para indicar quais programas a universidade adotava visando apoio a pesquisa e estimular o contato com a produção acadêmica. No quadro abaixo, são descritos os programas da universidade pesquisada.

Quadro 1 - Programas de apoio à pesquisa da universidade pesquisada.

\begin{tabular}{|l|l|l|}
\hline $\begin{array}{l}\text { 1. FAPIC (Bolsa Institucional de } \\
\text { Iniciação Científica) }\end{array}$ & $\begin{array}{l}\text { 4. Política de Internacionalização da } \\
\text { Pesquisa (PROINTER) }\end{array}$ & $\begin{array}{l}\text { 7. Programa de Estímulo à } \\
\text { Formação de Pesquisadores }\end{array}$ \\
\hline 2. PIBIC / CNPq & 5. Projetos Tecnológicos (PROTEC) & $\begin{array}{l}\text { 8. Programa Professor Parceiro } \\
\text { em Pesquisa }\end{array}$ \\
\hline $\begin{array}{l}\text { 3. Política de Incentivo à Captação } \\
\text { de Recursos (PICR) }\end{array}$ & $\begin{array}{l}\text { 6. Programa de Incentivo à Produção } \\
\text { Científica (Conceito 5) }\end{array}$ & 9. Escola da Ciência \\
\hline
\end{tabular}

Disponível em: (Soares; Severino, 2018, p. 375).

O que se destaca é que a iniciação científica perpassa o curso de graduação e licenciatura em pedagogia em todas as disciplinas. Desse modo, ao oferecer a leitura e escrita de textos científicos aos alunos, ocorre um processo de ensino e aprendizagem significativa. Essa aprendizagem desenvolve habilidades de aprender a lidar com dificuldades, uma vez que, são experiências significativas na vida de cada aluno. 
Em uma análise final, o estudo de Soares; Severino (2018) aponta que Ausubel desenvolve a iniciação científica com vista a aprendizagem significativa. Já Demo, aponta como um princípio educativo da pesquisa. Severino define esse procedimento como aprendizagem na construção do conhecimento. Na sequência, passamos a discutir as práticas de formação acadêmica realizadas no curso de pedagogia da Anhanguera Sertãozinho.

\section{A formação acadêmica: análise do curso de Pedagogia na Anhanguera Sertãozinho}

No texto de Osvaldo Oliveira Junior (2015) publicado pelo Instituto de Física da USP - São Carlos, o autor pontua que a comunicação entre a ciência e a sociedade ocorre por meio da produção de artigos e os referidos canais de comunicação. Nesse sentido, para que seja conhecido, um trabalho de pesquisa em forma de artigo deve ser criteriosamente planejado e resolver problemas de ordem científicas - tecnológicas. Para ampliar o contato dos estudantes universitários com a produção desses artigos científicos, o curso de Pedagogia da Anhanguera Sertãozinho se estrutura com disciplinas de práticas pedagógicas.

Alguns elementos essências na composição do artigo são fundamentais para que se possa realizar uma compreensão do mesmo. Osvaldo Oliveira Junior (2015) pontuou que esses elementos são: título, resumo, introdução, materiais e métodos, resultados, discussão, conclusão, agradecimentos e referências. Para que o aluno possa ter contato com a uma literatura ampla e de qualidade, a Anhanguera disponibiliza para os alunos uma plataforma digital, onde a biblioteca possui acesso a uma vasta base de dados, periódicos, revistas e livros virtuais. Essa base é utilizada pelos professores do curso com indicações de referências bibliográficas nos planos de ensino, bem como, ao longo do componente curricular ministrado no curso de Pedagogia.

Ao refletir sobre os saberes que desenvolvem a atividade prática na formação docente, o curso de Pedagogia da Anhanguera de Sertãozinho se propõe a pensar na prática como um elemento fundamental na articulação entre formação de professores e um exercício didático na resolução de situações problemáticas que conciliem a teoria e a prática. Essa articulação é a busca de alternativas para a compreensão dos problemas e necessidades de se pensar a formação de professores no Brasil, dando sentido às idéias, à teoria e à prática.

Ressaltamos, que os cursos de formação de professores, sobretudo pedagogia, devem priviliegiar na organização do seu currículo, os 
saberes profissionais no aspecto teórico e submetê-lo à realidade. Esse processo leva o desenvolvimento das disciplinas em um contexto teóricoprático. Pensar em uma atividade, ao longo da formação é despertar a reflexão dos saberes podem se realizar de maneira simultanea. A prática está aqui orientada pela teoria. Nesse sentido, Barreiro e Gebran argumentam:

\begin{abstract}
[...] que a formação inicial dos professores deve pautar-se pela investigação da realidade, por uma prática intencional, de modo que as ações sejam marcadas por processos reflexivos entre os professores-formadores e os futuros professores, ao examinarem, questionarem e avaliarem criticamente o seu fazer, o seu pensar $e$ a sua prática. (BARREIRO e GEBRAN, 2006, p. 21)
\end{abstract}

Sendo assim, a prática do saber docente será orientada por uma processo formativo pela prática e sustentado por teorias da educação. A teoria é parte essêncial do processo de formação dos docentes. Essa teoria alicerça a identidade do sujeito permitindo a constução de subsídios para uma ação contextualizada, ou seja, uma compreensão histórica, social e cultural de si próprio como profissional do campo da educação.

Nos cursos de pedagogia e de formação de professores há uma incumbência em torno de um projeto pedagógico que favoreça a articulação entre teoria e prática, contextualizando e inserindo espaços concomitantes entre as áreas propiciando em sua formação uma visão dos conteúdos aprendidos de modo a aplicá-lo em disciplinas específicas que servirão como referencial em sua atuação profissional. A visão prática quanto aos conteúdos será investida tendo como base o conhecimento dos conteúdos a serem ensinados e como devem ser ensinados.

Ao analisar a obra Os Novos Rumos da Licenciatura, produzido por Vera Candau, já em 1988, observa-se que a autora estudou e realizou uma investigação tendo como referencial a problemática dos cursos de licenciaturas. Em sua análise, ela procurou detectar os pontos de confluência ou de diferenciação quanto aos profissionais de áreas específicas do conhecimento. Em relação aos desafios encontrados nos cursos de licenciaturas, percebe-se que:

\begin{abstract}
a falta de domínio dos conteúdos específicos e pedagógicos e das habilidades técnicas por parte do professor; a falta de integração entre as unidades de educação e as demais unidades, assim como o sistema de formação do futuro docente e o sistema que o irá absorver como profissional; a falta de articulação entre teoria e prática, entre conteúdo e método, entre bacharelado e licenciatura. (CANDAU, 1988, p.82)
\end{abstract}

Desta maneira, algumas questões podem ser identificadas: a primeira no sentido de qual é o lugar ocupado pela formação de professores na 
maneira pela qual a universidade brasiliera está organizada. A segunda é, qual a solução apontada para a problemática enfrentada nos cursos de Licenciatura considerando uma abordagem interdisciplinar e integrada. Dentro desse cenário, a formação de professores é um processo que, em geral, se vê pouco valorizado na formação acadêmica. O reflexo dessa desvalorização, perpetua uma ordem hierárquica entre o desenvolvivmento de pesquisas, atividades de graduação e pós-graduação. A dedicação nos cursos de licenciaturas se volta em grande parte ao ensino e ao estágio acadêmico. A existência do distânciamento entre a universidade e a a formação de professores se configura coma manutenção de uma visão razoável da realidade das escolas e e das vivências em contextos escolares.

\section{Práticas e Metodologias utilizadas na formação universitária do curso de Pedagogia na Anhanguera Sertãozinho}

Nesse último tópico, dedicamos uma especial análise ao que é feito na prática, ou seja, como a proposta pedagógica do curso de Pedagogia se efetiva na universidade pesquisada. Os materiais analisados como instrumentos de avaliação foram o Projeto Pedagógico do Curso, as práticas pedagógicas realizadas pela coordenação do curso e a matriz com competências técnicas e transversais do curso de pedagogia

Nessa perspectiva, o que se propõe no projeto pedagógico do curso de Pedagogia quanto a formação de professores é que a prática esteja inserida no desenvolvimento de todas as áreas ou disciplinas da matriz pedgógica. Com esse objetivo, o curso desenvolve habildiades para que 0 futuro professor tenha subsídios para usar os conhecimentos que aprendeu ao longo de sua formação e se aproprie de experiências significagtivas em diferentes momentos curriculares durante a sua graduação.

Desse modo, a coordenação do curso atua na dimensão prática, trazendo para o interior das áreas ou disciplinas, práticas e laboratórios didáticos que ampliem o espaço de atuação coletiva e integrada dos alunos. Essas práticas transcendem para além do estágio e tem como finalidade articular as diferentes práticas em uma perspectiva interdisciplinar, ou seja, criar possibilidade de uma formação completa. Destaca-se nesse processo o método de observação e reflexão para atuação em situações contextualizadas. Para Pimenta (2006),

À primeira vista a relação teoria e prática é bastante simples. A prática seria a educação em todos os seus relacionamentos práticos e a teoria seria a ciência da Educação. A teoria investigaria a prática sobre a retroage mediante conhecimentos adquiridos. A prática por sua vez, seria o ponto de partida do 
conhecimento, a base da teoria e, por efeito desta, torna-se prática orientada conscientemente. (PIMENTA, 2006, p. 99)

Uma outra dimensão relaciona-se ao perfil dos alunos dos cursos de pedagogia na Anhanguera de Sertãozinho. A maior parte do público é formada por um grupo de alunos que já trabalha, sendo alguns, na área de educação. Contudp, não necessariamente muitos atuam no magistério. Foi verificado também, que devido a rotina de trabalho, os mesmo dispõe de pouco tempo e poucos recursos para desenvolver um curso. Sendo assim, as práticas realizadas dão sentido e significado no que é realizado. Nesse contexto a instituição de ensino superior privado, forma os professores para uma atuação ativa, na valorização do saber escolar.

$\mathrm{Na}$ disciplina de práticas pedagógicas, os alunos das séries iniciais possuem o primiero contato com a escrita e o saber científico. Nessa disiciplina, o aluno têm contato com diferentes artigos e obras que possibilitam a construção do texto acadêmico. Essa prática de leitura e escrita favorece a produção do conhecimento e do saber. Ao final do semestre, produzem um trabalho com revisão bibliográfica dos artigos que foram abordados ao longo do conteúdo abordado.

Esse diferencial de unir a prática, a teoria, a produção de pesquisa e a escrita acadêmica tem se consolidado como o diferencial da instituição. A formação de professores é vista não só na perspectiva da autonomia estudantil, mas também como na capacitação do uso de metodologias ativas no seu processo formativo.

\section{CONSIDERAÇÕES FINAIS}

Observou-se que o número de alunos com produção acadêmica na produção dos Trabalhos de Conclusão de Curso e a continuidade de estudos na modalidade pós-graduação foi maior após a participação dos alunos nas práticas realizadas junto as disciplinas do curso. Além disso, os docentes desenvolveram habilidades necessárias para a prática docente durante o período de formação.

A partir do exposto, fica a reflexão: o desenvolvimento de práticas e laboratórios pedagógicos no curso de formação de professores é um caminho na construção da interação e atuação dos futuros docentes. Nesse contexto, as diretrizes educacionais e matrizes do curso devem ser organizadas ligadas à realidade escolar que os alunos encontrarão na sala de aula quando docentes. Cabe, portanto, nesse processo de formação de professores não utilizar a sala de aula apenas como uma reprodução do conhecimento de forma 
descontextualizada com a realidade; em contrapartida, as práticas têm grande competência para aplicar propostas com sentido na formação da carreira.

A familiarização dos estudantes com as situações-problemas propostas ao longo do processo de ensino e aprendizagem auxiliam a formação do educador. Casa situação-problema apresentada nas disciplinas que compõe a grade curricular constroí diferentes relações entre o aluno, o professor e o saber. A relação que se consolida fortalece as distintas variáveis didáticas presentes nessas situações.

\section{REFERÊNCIAS}

ANDRÉ, M. Pesquisa em educação: buscando rigor e qualidade. In: Cadernos de Pesquisa. N.113 - p-51-54 julho/2001

BARREIRO, I. M. F.; GEBRAN, R. A. Prática de Ensino e Estágio Supervisionado na Formação de Professores. São Paulo: Avercamp, 2006.

BARRENECHEA, Cristina Azra. Redação Científica como o uso de ferramentas tecnológicas. UFPR. Curitiba, 2016.

BOGDAN. R.C. BIKLEN. S.K. Investigação qualitativa em educação. Lisboa: Porto Editora, 1991.

CALADO, Sílvia dos Santos. FERREIRA, Silvia Cristina dos Reis. Análise de Documentos: Método de recolha e análise de dados. In: Metodologia da Investigação I - DEFCUL. 2003-2004.

CANDAU, Vera Maria; KOFF, Adélia Maria Nehme. Conversas com ... sobre a didática e a perspectiva multi/intercultural. Educ. Soc., Campinas, Vol. 27, nำ5, maio/ago. 2006, p. $471-493$

CANDAU, V. (coord.). Novos rumos da licenciatura. In: Estudos e Debates 1 Brasília: INEP; Rio de Janeiro: PUC/RJ, 1988, 93p.

CUENCA, Angela Maria Belloni. PAULA, Dulcenéa de. FRANÇA JUNIOR, Ivan. Desenvolvimento da habilidade na escrita e produção científica: cursos são necessários? In: Revista Eletrônica Comun Inf Saúde. jul-set; 11(3), 2017.

GUNTHER, Hartmut. Pesquisa Qualitativa Versus Pesquisa Quantitativa: Esta é a questão?. In: Psicologia, Teoria e Pesquisa. Maio-Ago 2006, Vol 22 n.22, pp.201-210.

LIBANEO, José Carlos. A Didática e a aprendizagem do pensar e do apreender: a teoria Histórico - cultural da Atividade e a contribuição de Vasili Davydov. Revista Brasileira de Educação. nº 27, p.5-24. Set/Out/Nov/Dez 204 
MENGA, Ludke. ANDRÉ, Marli E.D. A. Pesquisa em educação: abordagens qualitativas. Editora pedagógica. São Paulo, 1986.

MINAYO. MC \& Sanches. Quantitativo-qualitativo: oposição ou complementaridade? Caderno de Saúde Pública. v.9 (3) p. 239-262, Ano. 1993

NEVES, José Luís. Pesquisa qualitativa: características, usos e possibilidades. Caderno de Pesquisas em Administração, São Paulo, v. 1, n. 3, 1996.

OLIVEIRA JUNIOR, Osvaldo N. A técnica de escrita científica. In: Revista Brasileira do Ensino de Física, v. 37, n.2. Brasil, 2015.

PERRENOUD, P.et al. Formando Professores profissionais: quais estratégias? Quais competências? 2 ed. Trad. Fátima Murad e Eunice Gruman. Porto Alegre:Artmed, 2001.

PIMENTA, S. G. O estágio na formação de professores: unidade teoria e prática? 7. ed. São Paulo: Cortez, 2006.

STOCKMANNS, Jussara Isabel. PEREIRA, Viviane Aparecida T. A escrita acadêmica: desafios do ato de escrever na educação superior. In: EDucere Congresso Nacional de Educação. Curitiba, 2017.

TRAINA, Agma Juci Machado; TRAINA JR, Caetano. Como fazer pesquisa bibliográfica. SBC Horizontes, v. 2, n. 2, p. 30-35, 2009.

VENTURA, Magda Maria. O estudo de caso como modalidade de pesquisa. Revista da Sociedade de Cardiologia do Estado do Rio de Janeiro, Rio de Janeiro, v. 20, n. 5, p. 383-386, set./out. 2007. 


\title{
PROFISSÃO DOCENTE E OS TEMAS TRANSVERSAIS: Algumas considerações
}

\author{
FERREIRA, Luís Henrique de Souza \\ Mestrando - UNESP Franca \\ luishenriquesferreira@hotmail.com \\ FONSECA, Genaro Alvarenga \\ Docente - UNESP Franca \\ Ga.fonseca@unesp.br
}

\section{INTRODUÇÃO}

A lei 9394/96, onde fundamenta-se a Diretrizes e Bases da Educação Nacional, mais especificamente no artigo 22, aponta um dos caminhos a serem seguidos pela Educação Básica no Brasil, nos dizeres: “(...) A educação básica tem a finalidade de desenvolver o educando, assegurar-lhe a formação comum indispensável para o exercício da cidadania e fornecer-lhe meios para progredir no trabalho e em estudos posteriores".

Um dos objetivos do ensino básico, seguindo como princípio a Constituição Federal do Brasil de 1988, deve-se comprometer a articulação de conhecimento, competência e valores, com a finalidade de capacitar os estudantes a utilizarem-se das informações para a transformação de sua própria realidade através do exercício da cidadania.

O ensino dos temas relacionados a cidadania está inserido oficialmente nos Parâmetros Curriculares Nacionais, através da nomenclatura "Temas transversais". Estes temas dizem respeito a conteúdos de caráter social, que devem ser incluídos no currículo, de forma "transversal", não se constituindo uma área de conhecimento especifica, mas como conteúdo a serem ministrados no interior das disciplinas tradicionais estabelecidas.

De acordo com os Parâmetros Curriculares Nacionais apresentados pelo MEC em 1997 no capítulo dedicado a Apresentação dos Temas Transversais, “... o trabalho didático com as áreas não é suficiente para cobrir toda a demanda dos Temas Transversais. Há um sério trabalho educativo a ser feito no âmbito do convívio escolar". (PCN, 1997. p. 39). Esta declaração dos PCN insere a problemática antiga da área do currículo: as disciplinas tradicionais não abordam um conjunto de questões postas pela realidade vivida pelos alunos. 
Nos próprios documentos oficiais do MEC 6 é reconhecida a necessidade da abordagem dos conteúdos "tradicionais" do currículo com referência a vida cotidiana dos alunos. "Há questões urgentes que devem necessariamente ser tratadas como a violência, a saúde, o uso de recursos naturais, os preconceitos, que não têm sido diretamente contemplados por essas áreas". (PCN, 1997. p. 23).

Diversas tentativas vêm sendo feitas ao longo dos anos para integrar as disciplinas escolares clássicas, com a suposição de que essa integração permitiria uma melhor apreensão da realidade. Elizabeth Macedo (1999) argumenta que:

Os PCN nos põem de novo diante de um problema antigo na área de currículo: as disciplinas tradicionais não dão conta de um conjunto de questões postas pela realidade vivida pelos alunos..., o documento (PCN) aponta a importância das disciplinas para que os alunos dominem o saber socialmente acumulado pela sociedade. Por outro lado, 'há questões urgentes que devem necessariamente ser tratadas, como a violência, a saúde, o uso de recursos naturais, os preconceitos, que não tem sido diretamente contemplado por essas áreas' (fragmento retirado da apresentação dos PCN). Poderíamos, então, perguntar: se o saber socialmente acumulado não dá conta de entender a realidade e seus problemas mais urgentes, porque ele é tão importante e central na escola? (MACEDO, 1999, p.43-44)

As disciplinas tradicionais, não cumprem com a função de orientar os alunos sobre assuntos que dialogam diretamente com seu cotidiano, a escola precisa, segundo os Parâmetros Curriculares Nacionais, se preocupar em tratar valores quanto conhecimentos, que permitam desenvolver nos alunos capacidades necessárias para sua participação na comunidade em que está inserido.

Colocamos o questionamento: são as disciplinas clássicas do currículo brasileiro, capazes de desenvolver no cidadão capacidades necessárias para sua participação social efetiva? Na literatura pedagógica, esta preocupação sempre foi constante, mas ainda sem respostas efetivas. Nos ambientes escolares, ainda podemos ouvir o questionamento dos alunos, referente a utilidade dos conhecimentos oferecidos pelas disciplinas clássicas frente aos seus desafios cotidianos.

Estes mesmos documentos apontam a importância dos conteúdos atualmente ministrados para que os alunos dominem o saber socialmente acumulado pela sociedade, mas também apontam a necessidade dos temas transversais, mas não apontam uma forma de integrar estas disciplinas. Tentativas como estas foram feitas através da proposta do PCN de 1997 ao propor os temas transversais.

\footnotetext{
${ }^{6}$ Ministério da Educação e Cultura. Em 1997 - Ano em que foi estabelecido os PCN. O Ministro da pasta era Paulo Renato de Souza.
} 
No volume introdutório dos PCNs, é colocado as reais condições em que as escolas brasileiras se encontram, e aponta que, para a concretização das propostas contidas nos Parâmetros:

“... uma política educacional que contemple a formação inicial e continuada dos professores, uma decisiva revisão das condições salariais, além da organização de uma estrutura de apoio que favoreça o desenvolvimento do trabalho (acervo de livros e obras de referência, equipe técnica para supervisão, materiais didáticos, instalações adequadas para a realização do trabalho de qualidade), aspectos que, sem dúvida, implicam a valorização da atividade do professor. (BRASIL, 1997, p.38)

As disciplinas clássicas atuais do currículo brasileiro, trazem uma hegemonia do pensamento positivista do século XIX que definiu os limites entre a ciência e o senso comum, o qual se baseou os conteúdos com os quais trabalhamos atualmente no currículo brasileiro. Onde as ciências foram separadas da realidade dos "homens" e assim foi se fragmentando e especializando, afastando o conhecimento de sua real utilidade. Criando assim uma barreira entre as ciências naturais e as ciências sociais.

Goodson (1993) vem se dedicando ao conhecimento da gênese das disciplinas escolares, sua entrada e legitimação dos currículos e este autor coloca que as disciplinas se constituem inicialmente com objetivos pedagógicos utilitários, com aspectos práticos da realidade, mas com o passar do tempo, se tornam cada vez mais acadêmicas. Esta especialização se dá depois da inclusão do conteúdo no currículo, as universidades criam cursos de formação de professores para este conteúdo e com isso o mundo acadêmico especializa cada vez mais neste conteúdo, e consequentemente o afasta da realidade e da importância para o fim que foi constituído. Goodson (1993), apoiado nos modelos de Layton aponta três etapas da evolução da disciplina escolar sendo: 1 - o primeiro estágio é a introdução da disciplina no currículo escolar com base em justificativas de pertinência e utilidade; 2 - no segundo estágio estabelece a tradição acadêmica para a disciplina e assim é formado os especialistas que passam a atuar como professores e no 3 - a disciplina passa a ter professores treinados e regras estabelecidas.

Macedo (1999) coloca:

Segundo os estudos históricos sistematizados por Goodson, a maioria das disciplinas escolares estabelece-se no currículo não por constituir áreas cientificas importantes na sociedade, mas por se mostrar capaz de lidar com os problemas cotidianos da vida em sociedade [...] hoje justificaríamos o surgimento de espaços para o estudo do meio ambiente, das doenças sexualmente transmissíveis, das regras de transido. Ao mesmo tempo em que a entrada de uma disciplina no currículo associa-se a utilidade pratica, imediata, sua manutenção depende da formalização do campo de estudos. (Macedo, 1999, p.50-51.) 
Podemos observar que a ideia de utilidade do conhecimento, muito embora seja proclamada como fundamental nos documentos oficiais e nos discursos educacionais, a mesma tende a não se transformar em realidade, negligenciando desta forma o ensino voltado a reflexão e a formação de cidadãos. O autor Phillippe Perrenoud (2005) defende o ensino voltado a formação para cidadania, e que desta forma, o conhecimento poderia trazer a superação de barreiras sociais geradas pela ignorância. Para Perrenoud, de nada adianta o aluno saber detalhadamente a organização do Estado, quando ele não consegue cumprir tarefas cotidianas, como preencher uma declaração de imposto, verificar seus direitos e seus deveres, desenvolver posicionamentos a respeito de questões sociais e políticas. $O$ ensino deve ser capaz de promover o aprendizado, reflexão e critica, para que então seja efetivo. PERRENOUD (2005)

É demonstrada a preocupação dos documentos oficiais educacionais brasileiros em fornecer aos alunos um conhecimento que seja relacionado ao seu cotidiano e que o aprendizado tenha uma relação direta com suas questões pessoais.

Macedo (1999) também aponta:

Os temas transversais propostos pelo MEC apresentam-se como mais uma tentativa de articulação entre as diferentes disciplinas que compõem o currículo, tendo por justificativa a incapacidade dessas mesmas disciplinas de dar conta da realidade social. A forma de articulação não está bem definida, o que nos leva a imaginar que dificilmente se efetivará no currículo vivido das diferentes escolas do pais. (MACEDO, 1999. p. 55)

Sabemos que para proporcionar aos alunos reflexões sobre diferentes possibilidades de conhecimento, o primeiro ator que devemos olhar, além dos alunos, seria então os professores. Ressaltando desta forma, a problemática que envolve este artigo.

Os próprios documentos orientadores das Licenciaturas no Brasil, colocam que os temas transversais devem ser contemplados na formação desses profissionais, nos dizeres:

O curso de Licenciatura deverá ser orientado também pelas Diretrizes
para a Formação Inicial de Professores da Educação Básica em
cursos de Nível superior. As instituições devem assegurar que o
graduando possa realizar atividades acadêmicas optativas em áreas
correlatas de modo a consolidar a interlocução com outras áreas de
conhecimento. No caso da licenciatura deverão ser incluídos os
conteúdos definidos para a educação básica, as didáticas próprias de
cada conteúdo e as pesquisas que as embasam. (BRASIL, 2001, p.8-
9)

As formas de se entender a transversalidade refletem a concepção metodológica de cada professor. Moreno (1998) coloca que: 


\begin{abstract}
"Se os temas transversais forem tratados como novos conteúdos a acrescentar aos já existentes, cumprirão apenas a função de sobrecarregar os programas e dificultar a tarefa do corpo docente, sem qualquer benefício para os estudantes, pois isto pressupõe tratar uma nova temática, com velhos procedimentos, eliminando assim todo o valor inovador que ela possa ter" (Moreno, 1998, p.36-37)
\end{abstract}

A viabilidade dos temas transversais em sala de aula, requer dos professores uma preparação anterior para desenvolverem metodologicamente estes conteúdos. Como foi instituído em 1997, as discussões e a didática relativa a estes temas não foram contempladas na formação da maioria dos professores em sala de aula atualmente, mesmo os professores recémformados e em processo de formação, encontram dificuldade em trabalhar estes temas e o faze-los de forma transversal e interdisciplinar.

Mediante o que discutimos acima, nesta pesquisa vamos verificar através de Revisão Bibliográfica os principais obstáculos que os professores encontram para colocar o que estabelecido nos PCN sobre os temas transversais e aplica-los em sala de aula

A cidadania se faz importante para o desenvolvimento educacional e social dos alunos, partindo da problemática em como este ensino para a formação de cidadãos críticos está sendo realizado no Brasil. Nos baseando na importância da articulação do conhecimento que relacione as disciplinas escolares com o cotidiano dos alunos, onde os mesmos possam desenvolver maior interesse pelos conteúdos escolares, deixando de achar as disciplinas "inúteis" podendo assim, utilizar o que é apreendido nas escolas, com os seus desafios do cotidiano, como exercendo uma postura crítica e reflexiva na comunidade em que vive, se qualificando para o mercado de trabalho e etc. Esta metodologia é anunciada pelo PCN através do título de "Temas transversais", onde não se constitui uma disciplina, mas sim temas que devem perpassar as referidas disciplinas afim de promover conteúdos que se relacionem com o dia-a-dia dos alunos.

Identificamos através de pesquisas nas áreas educacionais que 0 ensino preocupado com a preparação dos educandos para um conhecimento crítico e reflexivo e que os prepara para o exercício de seus direitos e deveres, muitas vezes é negligenciado por diversos fatores, começando com o descaso dos documentos oficiais com a efetivação do que eles mesmos propõem, passando pelos materiais didáticos até na formação dos professores.

Nos apoiando nesta última problemática, este artigo irá identificar através de pesquisas já realizadas com docentes, suas opiniões, discussões e problemas que encontram para ministrar as aulas abordando os temas transversais.

Esta pesquisa fez o uso da metodologia "Revisão Bibliográfica" através do cruzamento de dois descritores: Professores e Temas Transversais 
nas bases de dados da Scientific Electronic Library Online (Scielo) e na Coordenação de Aperfeiçoamento de Pessoal de Nível Superior (CAPES), onde buscamos produções científicas publicadas desde 1997 (ano de publicação do PCN) até o ano atual, afim de verificar as principais pesquisas que foram realizadas para identificar a profissão docente e o tratamento dos temas transversais em sala de aula.

A partir dos documentos, artigos, livros, periódicos encontrados, foi feito a leitura dos Títulos e resumos afim de identificar as pesquisas realizadas com os objetivos propostos por este presente estudo. Filtradas por "periódicos revisado por pares" e foram excluídas pesquisas feitas em outros países e publicadas em línguas estrangeiras, justifica-se as exclusões por este presente trabalho ter por objetivo pesquisas nas escolas e com professores brasileiros.

\title{
4. DESENVOLVIMENTO DE TEMAS TRANSVERSAIS
}

MARINHO, SILVA e FERREIRA (2015) realizaram uma pesquisa, onde trouxeram algumas concepções de professoras dos anos iniciais do ensino fundamental, de uma determinada escola da rede municipal de Rio Grande/RS, e as questionam sobre a educação em saúde, um dos temas transversais, em suas práticas educativas cotidianas. Esta pesquisa foi feita através de 12 entrevistas semiestruturadas. Colocam que, de acordo com as falas das professoras, o tratamento das questões de saúde sofre de sistematização, ações e práticas, onde as professoras relataram que a abordagem deste tema se dá de forma esporádica e eventual. E concluem que:

\begin{abstract}
Em relação ao pensamento docente sobre o tema transversal saúde, um dos temas transversais elencados pelo MEC nos PCN, percebemos a dificuldade que os professores encontram em trabalhar com esta temática. Evidenciamos como principal marca o não reconhecimento da saúde como conteúdo de ensino, bem como a dificuldade de implementação de um trabalho interdisciplinar e transversal em uma dada organização curricular historicamente construída. Pensamos que, para superar essa visão, precisamos desenvolver a cultura da transversalidade a qual implica uma mudança na perspectiva do currículo escolar. (Marinho, Silva e Ferreiro. 2015, p.441)
\end{abstract}

Mary Neide Damico Figueiró (2000), no periódico intitulado "A viabilidade dos Temas Transversais à luz da questão do trabalho docente" apresenta a contribuição de Mizukami (1998) no V Congresso Paulista sobre formação de educadores, onde a mesma apresenta as competências que 0 professor precisa ter para que os PCNs se concretizem:

1 - Planejador central do currículo e do ensino

2 - Ser a figura central do processo ensino-aprendizagem 

3 - Avaliador do progresso do aluno e observador dos eventos da sala de aula
4 - Educador do desenvolvimento pessoal de cada aluno
5 - Ser agente do seu processo de aprendizagem e desenvolvimento profissional
6 - Conhecer profundamente as Áreas de Conhecimentos e dos "temas transversais"
7 - Educador de estudantes diversos
8 - Participar do projeto educativo da escola. (Figueiró, 2000, p. 3)

Figueiró (2000) aponta que no momento da criação dos PCNs, é esperado que professor seja um "super profissional", apresentando uma formação de qualidade, mas que é de comum acordo que não condiz com a realidade. Figueiró coloca a seguinte problematização: "Será que o professor conhece conteúdos de outras áreas de conhecimento além das de sua área de formação? Será que conhece, os temas sociais que deverá abordar 'transversalmente'?" (Figueiró, 2000, p. 4)

Figueiró (2000), utilizando-se de alguns autores como Bueno(1996) e Gentili (1995) e Davini (1997), expõe que o professor precisa tomar consciência de que o Estado controla a formação e o trabalho docente, e assim, sua preocupação inicial é a formação para o trabalho de forma tecnicista, onde os professores devem ter debates e reflexões em grupo e crítica ao conhecimento sistematizado e construção do saber cotidiano do professor e conclui seu periódico com os seguintes dizeres:

Finalizando, pode-se dizer que a viabilização dos "temas transversais" é um processo difícil, longo, porem viável, que requer uma construção em coletividade. Os resultados de sua aplicação podem ser bastante promissores, por se tratarem de temas que, a se aprimorarem como cidadãos. Em especial aos temas de pluralidade cultural e orientação sexual são muito uteis para ajudar professores e alunos a entenderem o processo de construção histórico-social dos valores da sociedade, sejam eles culturais, morais e religiosos, entre outros, para poderem participar do processo de transformação social. (Figueiró, 2000, p. 12-13)

Mediante a busca proposta na metodologia deste trabalho, selecionamos uma pesquisa realizada pelas autoras Elidiane Oliveira e Thamyres Rodrigues, onde apresentaram no III Conedu (Congresso Nacional de Educação) um estudo em forma de artigo de título "Abordagem dos Temas Transversais: A percepção dos professores de duas escolas públicas de Ensino Médio".

Foram abordadas duas pesquisas realizadas: Um estudo de Ricardo e Zylbersztajn (2002)7 onde estes autores relataram que as principais dificuldades apontadas pelos professores foram a falta de material didático que esteja de acordo com os PCN e os temas transversais, falta de metodologia e a

\footnotetext{
${ }^{7}$ FIGUEIREDO, D.M.;PELEGRINI, A.F. Educação ambiental e o ensino de matemática: uma pratica metodológica na 5a serie do ensino fundamental.
} 
dificuldade em encontrar tempo para planejar aulas interdisciplinares e que se contextualizem com o currículo. A segunda apontada pelas autoras deste artigo, é de ALMEIDA (2006)8 onde o autor realizou estudos com professores de Ciencias a respeito dos Temas Transversais no Estado da Bahia e através de questionários, pode perceber que a abordagem destes temas é limitada pelo fato da maioria dos professores priorizarem os Livros Didáticos e possuírem um conhecimento superficial do tema. Nesta mesma pesquisa é apontada algumas frases dos professores ao serem questionados sobre a dificuldade em abordar os Temas Transversais: "Falta de tempo", "Conscientizar os alunos sobre a relevância do tema para a formação dele e a falta de tempo", "poucas horas de aula".

A Associação Brasileira de Ensino de Biologia publicou em sua revista de n. 7 em outubro de 2014 um artigo dos Autores, Santos, Fonseca, Tavares e Moro intitulado "Temas Transversais - Enfoque na abordagem e desenvolvimento de temas com ênfase em drogas em um colégio particular de Belo Horizonte" onde os autores, apresentaram uma investigação realizada sobre a abordagem e o desenvolvimento dos temas transversais dando ênfase ao tema das drogas. Sua metodologia foi a aplicação de questionários a três turmas do Ensino médio do colégio e aos professores que manifestaram interesse em participar.

No questionário dos alunos foram elencadas questões como:

1 - Se eles consideram que os professores abordam os temas transversais de maneira adequada; de um total de 38 alunos 89,5\% consideram que os professores abordam estes temas

2 - Se o colégio incentiva a abordagem; 78\% acredita que há o incentivo

3 - Se o tema das drogas licitas e ilícitas foram abordados; 96,2\% relataram que o tema já foi abordado

4 - E como poderiam ajudar um colega usuário; 66\% acreditam que poderia ajudar explicando as consequências do consumo

Apenas 4 professores aceitaram responder o questionário, onde a maioria respondeu que abordam os temas, que o colégio incentiva as abordagens, e que consideram os temas transversais descritos no PCN importantes. Mas durante a observação dos pesquisadores com os outros professores, destacaram que a maioria ainda constrói seus planos de trabalho voltados para suas áreas de conhecimento e com poucas brechas para abordagens dos conteúdos transversais. Relataram que muitos alunos

\footnotetext{
${ }^{8}$ ALMEIDA, T.J.B. Abordagem dos temas transversais nas aulas de ciências do ensino fundamental, no Distrito de Arembepe, município de Camaçari-BA. Cadombá Revista Virtual, Bahia, v.2, n.1, p. 1-23, Jan/Jun. 2006.
} 
reclamaram que poucas disciplinas tratam destas discussões ficando restrito a biologia, geografia, sociologia e filosofia. E terminam dizendo que quando os assuntos são abordados é de forma expositiva, sem muitos recursos de imagens e sons. Os autores se baseando em suas experiências na universidade terminam sua pesquisa concluindo que "a maioria dos professores se sentem despreparados para trabalhar essa temática e frequentemente experimentam a frustação com os resultados de seus trabalhos e atribuem isso a deficiente formação inicial e continuada".

Maria Judith Sucupira da Costa Lins publicou em 2007 um estudo intitulado "Avaliação da aprendizagem de ética em curso de formação de professores de Ensino Fundamental", onde seu objetivo foi o de descobrir como é ensinado e como os estudantes entendem a Educação moral, que nos Temas Transversais é nomeado de Ética. Em sua pesquisa a autora se preocupa em como este tema é trabalhado em sala de aula, e mediante a hipótese considerada, de que os professores em exercício não conseguem ensinar Ética por meio de situação em sala de aula porque suas formações foram negligentes enquanto a abordagem destes conteúdos. Suas metodologias utilizadas foram a "escuta sensível" onde foi possível que a autora compreendesse mais profundamente tanto os alunos como os professores através da observação e utilizou-se também de questionários apresentados como entrevista semiestruturadas. A pesquisa foi iniciada em 2005 e acompanhou 21 alunos a primeira série do Ensino médio e 11 professores em uma escola estadual do Rio de Janeiro. Após a obtenção dos dados, as informações foram categorizadas e assim se chegou aos resultados.

Durante o levantamento de dados, cabe ressaltar, que um dos resultados que a autora chega é que metade dos alunos desta escola, consideram o tema Ética de "muito valor". Se faz importante ressaltar os resultados encontrados pela autora, nos dizeres:

\footnotetext{
Os resultados da categorização feita a partir da análise dos dados obtidos nesta pesquisa qualitativa apontam uma falta de informação sobre Educação Moral/Ética de maneira geral. Notou-se o desconhecimento de conceitos básicos desta área do saber. Ao mesmo tempo, foi constatado que estes estudantes demonstraram um grande interesse sobre o tema pesquisado
}

No que diz respeito aos professores, as observações revelam que eles têm uma grande dificuldade para lidar com o tema, tanto conceitualmente como de ponto de vista didático. Parece-nos que eles precisam ter um preparo um pouco mais adequado no que se refere a introdução de Temas Transversais simultaneamente aos conteúdos de suas disciplinas, inclusive quanto á Ética, apesar da instituição destes pelo PCN desde 1997. (Lins, 2007, p. 274)

Com os resultados obtidos pela pesquisadora, observamos em mais uma experiência as conclusões sobre o despreparo dos professores frente aos temas transversais, neste caso, ao tema Ética. E conclui que nesta 
escola, a proposta do PCN sobre o ensino de temas ligados ao cotidiano dos alunos em forma transversal ainda está longe de ser efetivado.

Mediante o que foi discutido até este momento, apresentamos um trabalho realizado por alunos de uma universidade pública de São Paulo na cidade de Franca, onde os integrantes trazem para os professores oficinas com assuntos relacionados aos Direitos Humanos, com a intenção de promover um aperfeiçoamento e uma formação continuada aos docentes. No artigo intitulado "Fundamentos da cidadania para professores fundamentais" é exposto um projeto do Núcleo de Estudos da Tutela Penal e Educação em Direitos Humanos (NETPDH) da Universidade Estadual Paulista Júlio Mesquita Filho Campus de Franca-SP, em parceria com o Programa de Pós-Graduação em Direito (PPGD) da mesma faculdade. O projeto tem como objetivo:

\begin{abstract}
Capacitação de professores do Ensino Fundamental II ( $6^{\circ}$ ao $9^{\circ}$ ano) da rede estadual de ensino por meio de oficinas periódicas realizadas na sede da escola Lydia Rocha Alves, a fim de incentivar uma reciclagem dos profissionais da área de educação através de discussão de temas relacionados a cidadania e aos direitos humanos, enquanto meios para construção de uma sociedade que reflita na prática os ideais de justiça, igualdade, liberdade e fraternidade. Dentre os principais temas trabalhados pelos mediadores estão: democracia, racismo, homofobia, questão de gênero, preconceito, bullying, violência e discriminação. (CABRIOLI, 2012, p.244). GRIFO NOSSO
\end{abstract}

O trabalho desenvolvido pelos alunos da graduação e pósgraduação em Direito desta mesma universidade, colocam no artigo publicado que o propósito do projeto é difundir os conteúdos discutidos nas oficinas com os professores a fim de promover uma conscientização dos envolvidos com os temas trabalhados e assim repassar aos alunos as discussões levantadas, promovendo um novo ambiente de socialização. Partem da premissa de que a disseminação dos conteúdos dos Direitos Humanos trazem aos alunos a emancipação, nos dizeres: "Se propõe a discutir temas que tornem possível a emancipação dos sujeitos envolvidos, de forma a possibilitar-Ihes meios para a garantia efetiva daqueles direitos que muitas vezes já se encontram positivados, mas que não se manifestam na prática" (Cabrioli, 2012, p. 246)

Apontam em seus resultados parciais que já estava ocorrendo na unidade de ensino, um movimento para que os conhecimentos colocados nas oficinas sejam postos em práticas. Alguns professores já montaram uma atividade de duas semanas onde discorreram sobre os temas dos Direitos Humanos, esta atividade seria colocada no cronograma de aulas. Ao fim dos resultados e conclusões o artigo traz que a oficina promovida abre espaço para a aproximação da comunidade acadêmica que fica restrita aos muros da 
universidade com a comunidade local, esta aproximação se mostra eficaz na construção da cidadania.

\section{CONSIDERAÇÕES FINAIS}

O trabalho dos docentes está diretamente vinculado com 0 desenvolvimento dos temas transversais em sala de aula, sendo este, juntamente com os alunos os "atores do conhecimento". Sendo assim, este profissional deveria receber formação para exposição de tais recursos metodológicos, assim, ele estará alimentando e proporcionando diferentes maneiras de agir e pensar de seus alunos.

NOVOA (1991) coloca que a formação deve estimular uma perspectiva critico-reflexiva, que forneça aos professores os meios de um pensamento autônomo e que facilite as dinâmicas de autoformarão participada. Mediante está colocação Antonio Novoa, como pode então os docentes fornecerem tais conhecimentos para os alunos se os mesmos são privados deles em sua formação inicial e posteriormente nas formações continuadas. No próprio PCN é colocado esta preocupação com a formação dos professores para se adaptarem ao que propõe este documento: "Valorização do professorado como os principais produtores, articuladores, planejadores e mediadores do conhecimento socialmente produzido (BRASIL, 1998).

Esta problemática é colocada nas pesquisas que abordamos, onde as conclusões sugerem o que já colocamos como suposição inicial deste artigo, os professores não se sentem preparados muitas vezes para abordar os temas transversais em sala de aula. Citam a falta de tempo para preparação das aulas, a falta de material didático, e muitas vezes a falta de interesse dos próprios professores em trazer para escolas estas discussões, porque vários temas trazem em seus seios, polemicas que podem comprometer o próprio emprego do professor, então alguns assuntos tabus, mas de grande necessidade de serem tragos para sala de aula, são negligenciados e deixados para "escanteio".

Como foi estabelecido nos PCN's, o ensino transversal deve passar por todas as disciplinas e assim cada professor e currículo verifica a forma que vai aborda-la, assim, todos os cursos de licenciaturas deveriam colocar na formação de seus professores, discussões, debates, eventos, disciplinas que desenvolvam as reflexões que permeiam os temas transversais. Ao propor este ponto, temos consciência dos demais problemas que assolam a formação de professores no Brasil, mas esta discussão tem sua relevância nos dias atuais ao considerarmos a importância que estes assuntos têm em sala de aula. Diante o atual cenário político brasileiro, onde temos agora um aumento 
na participação popular nas discussões sociais, a escola se faz de grande importância para formação de cidadãos capazes de intervir criticamente na sociedade em que vivem.

Denise Nunes já aponta em sua obra, publicada em 1999, um ano após a publicação dos Parâmetros Curriculares:

“(...) é prudente salientar que a atual formação de professores não os habilita a abração causa de tal magnitude. Antes disso é fundamental que os setores responsáveis pela elaboração de políticas públicas educacionais despendam esforço de igual teor no sentido de viabilizarem a capacitação de professores em serviços, sendo necessário discutir a própria concepção de capacitação tanto em relação aos conteúdos como a forma de realização devido ao grande número de profissionais envolvidos. (NUNES, 1999, p.33)

Aos professores fica o cuidado para não transformar suas aulas em contadores de fatos, mas desenvolva em suas aulas: práticas de discussões, reflexões, trabalhos dinâmicos e assim colocar a transversalidade em seu cotidiano, envolvendo todos os alunos num clima de curiosidade, responsabilidade, investigação e prazer em aprender e ensinar.

\section{REFERÊNCIAS}

BRASIL. Parâmetros Curriculares Nacionais: Apresentação dos Temas Transversais, Ética. Brasília: MEC/SEF, 1997c. Disponível em: < http://portal.mec.gov.br/seb/arquivos/pdf/livro081.pdf > Acesso em: julho de 2019.

Parâmetros Curriculares Nacionais - Ensino Médio, 2000.

Disponível em: < http://portal.mec.gov.br/seb/arquivos/pdf/blegais.pdf >. Acesso em julho de 2019.

. Proposta de diretrizes para a formação inicial de professores da Educação Basica, em cursos de nível superior. Brasília: MEC, 2001.

CABRIOLI, José Vinicius. et. Al. Fundamentos da cidadania para professores fundamentais. Ver. Cienc. Ext., v.8, n.3, 2012, p. 244-249.

FIGUEIRÓ, Mary Neide Damico. A viabilidade dos Temas Transversais à luz da questão do trabalho docente. PSI Revista de Psicologia Social e Institucional. Londrina, v. 2, n.1, jun. 2000. Disponível em:

http://www.uel.br/ccb/psicologia/revista/textov2n12. Acesso em agosto de 2019.

GOODSON, Ivor F. Tornando-se uma matéria acadêmica: padrões de explicação e evolução. Teoria e Educação. Porto Alegre. 1990.

LINS, Maria Judith Sucupira da Costa et al . Avaliação da aprendizagem de ética em curso de formação de professores de Ensino Fundamental. Ensaio: 
aval.pol.públ.Educ., Rio de Janeiro , v. 15, n. 55, p. 255-276, Jun 2007 .Disponível em: < http://www.scielo.br/scielo.php?script=sci arttext\&pid=S0104$\underline{40362007000200006 \& \text { Ing }=e n \& n r m=i s o}>$. Acesso em setembro de 2019.

MACEDO, Elizabeth Fernandes. Parâmetros curriculares nacionais e a falácia de seus temas transversais. In: Currículo: Políticas e práticas. Papirus. Campinas. 1999. p. 4358.

MARINHO, Julio Cesar Bresonlin; SILVA, João Alberto da Silva; FERREIRA, Maira. A educação em saúde como proposta transversal: analisando os Parâmetros Curriculares Nacionais e algumas concepções docentes. História, Ciencias, Saúde - Manguinhos, Rio de Janeiro, v.22, n.2, abr-jun. 2015, p.429443.

MORENO, Montserrat.Temas Transversais: um ensino voltado para o futuro. In: Busquets, Maria Dolors (et alli). Temas Transversais em Educação-base para uma Formação Integral. 4ª Ed. SP: Ática, 1998.

NÓVOA, Antônio. Concepções e práticas da formação contínua de professores: In: Nóvoa A. (org.). Formação contínua de professores: realidade e perspectivas. Portugal: Universidade de Aveiro, 1991.

NUNES, Denise. Tecnologia e cidadania: Aprendizagem e capacitação de professores através da modalidade de ensino a distância. Dissertação (Mestrado em Engenharia de Produção). Florianópolis: UFSC/CTC, 1999.

OLIVEIRA, Elidiane Silva; RODRIGUES Thamyres Cavalcante. Abordagem dos temas transversais: A percepção dos professores de duas escolas públicas de ensino médio. IIICONEDU. Natal-RN, 2016. Disponível em: < https://docplayer.com.br/50160390-Abordagem-dos-temas-transversais-a-percepcaodos-professores-de-duas-escolas-publicas-de-ensino-medio.html > . Acesso em agosto de 2019.

SANTOS, Fernanda; FONSECA, Pablo Augusto; TAVARES, Marina; MORO, Luciana. Temas Transversais - Enfoque na abordagem e desenvolvimento de temas com ênfase em drogas em um colégio particular de Belo Horizonte. SBEmbio. n.7. Outubro de 2014. p. 2059-2071. 


\section{ÍNDICE}

\section{A}

ALVES, Maria Sílvia Rodrigues, 70

ANDRADE, Lucimary Bernabé

Pedrosa de, 9

ARAGÃO, Amanda Silva, 19

ASSOLINI, Filomena Elaine Paiva, 40

\section{B}

BANDOS, Rogério Dutra, 40

BORGES, Angelita Salomão Muzeti, 9

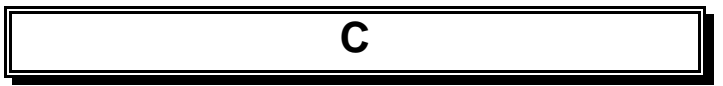

CAROTA, Filipe Pimenta, 19, 98

\section{$\mathbf{F}$}

FACIROLI, Ana Lívia Guimarães, 70 FERREIRA, Luís Henrique de

Souza, 108

FONSECA, Genaro Alvarenga, 108

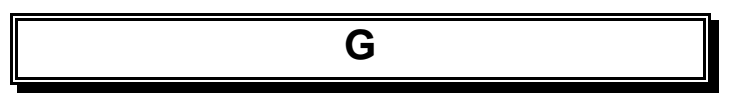

GIMENES, Priscila Alvarenga

Cardoso, 9

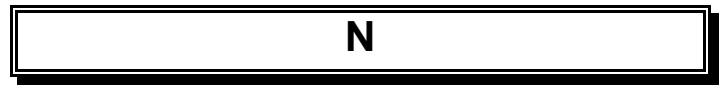

NASCIMENTO, Mari Clair Moro, 81

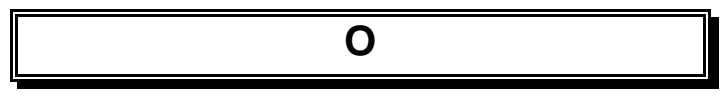

OLIVEIRA, Anelise Martinelli

Borges, 81

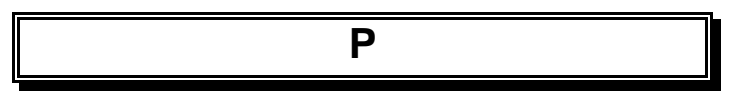

PERENTELLI, Léia Fernandes, 98 PETTA, Thiago Teixeira de, 55

S

SATAKA, Mayara Mayumi, 31

SILVA, Matheus Felipe, 31

V

VAGULA, Edilaine, 81

VIEIRA, Giovana Flávia, 70 

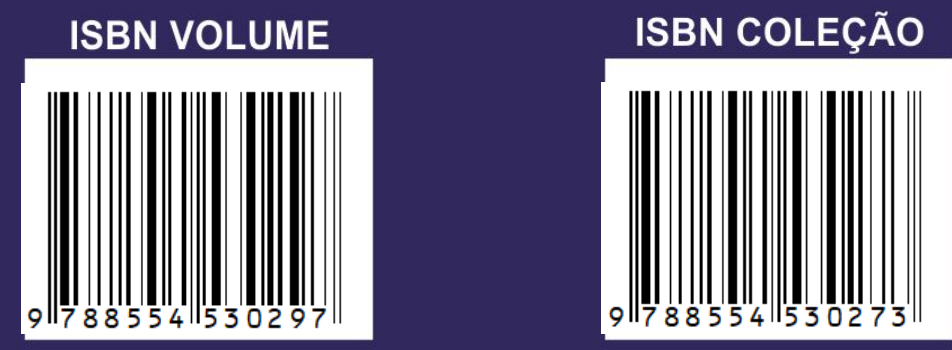

08009404688 | 163713.4688

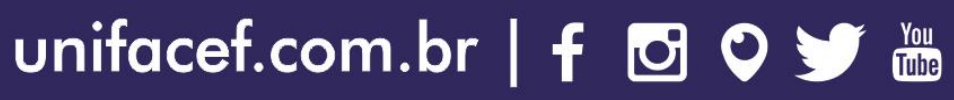

163706.8700

franca.unesp.br 